\title{
Article
}

\section{Judicial Review of Direct Democracy}

\author{
Julian N. Eulet
}

I. The Scope of Direct Democracy

II. Rethinking the Counter-Majoritarian Difficulty

A. Does Direct Democracy Accurately Reflect Majority Will?

B. The Constitutional Filtering of Majority Will

1. The Representation Filter

2. The Divided Power Filter

3. The Entrenched-Rights Safety Net

C. The Constitutional Context of Judicial Review

1. Is the "Difficulty" With Judicial Review Really a Counter-Majoritarian One?

2. Contextualizing the "Difficulty" With Judicial Review

D. Are States Laboratories for Unfiltered Experimentation?

† Professor of Law, University of California, Los Angeles. I would like to give special thanks to Justice Hans Linde of the Oregon Supreme Court for his helpful insights. The UCLA Law School community was, as always, wonderfully supportive. I am particularly grateful for the assistance afforded by my colleagues Joel Handler, Kenneth Karst, Alan Katz, Daniel Lowenstein, and Jonathan Varat, the UCLA Law Library staff, and James Gelb. Akhil Amar also offered extremely helpful commentary.

An earlier version of this Article was delivered on March 3,1989, at a conference entitled "From Gold Dust to Silicon Chips: Symposium on the California Constitution," sponsored by the University of California, Hastings College of the Law. The transcript of this speech is reprinted as Checking California's Plebiscile, 17 Hastings Const. L. Q. 151 (1990). 

1. The Federal Curb on State Experiments With Unfiltered Majorities
2. Judicial Review Under State Constitutions

III. Ghecking the Plebiscite

A. Judicial Review of Substitutive Plebiscites

1. Equality and Individual Rights at Risk

a. The Need For Filters

b. The Efficacy of Filters

2. The Outlines of a Hard Judicial Look

B. Judicial Review of Complementary Plebiscites 1573

C. Are State Courts Up to the Task? 1579

Conclusion: A Lingering DoubT

A nation that traces power to the people's will does not easily digest the practice of unelected and unaccountable judges' denying the populace what most of them appear to want. It is no wonder that a substantial portion of constitutional scholarship deals with the apparent tension between judicial review and majoritarian democracy. Judicial review in its conventional guise, however, does not entail a direct conflict between the judiciary and the people. It is instead the will of a legislature that is being thwarted in the name of the Constitution. In fact, this very lack of identity between the people and their representatives forms the foundation for Alexander Hamilton's defense of judicial review in The Federalist No. 78: "[W]here the will of the legislature declared in its statutes, stands in opposition to that of the people declared in the constitution, the judges ought to be governed by the latter, rather than the former." While we ordinarily engage in the fiction that legislative enactments represent majority will, ${ }^{2}$ we discard this fiction when courts find that the people's agents have acted beyond the power delegated to them by the constitutive document.

1. The Federalist No. 78, at 525 (A. Hamilton) (J. Cooke ed. 1961) [hereinafter all citations to the Federalist are to this edition]. In exercising judicial review, Hamilton concluded, the courts act not in contravention of the people but as "an intermediate body between the people and the legislature." Id. Although "representatives of the people, in a popular assembly, seem sometimes to fancy that they are the people themselves," Hamilton would have none of it. Id. No. 71, at 483-84 (A. Hamilton).

2. But see Ackerman, The Storrs Lectures: Discovering the Constitution, 93 Yale L.J. 1013, 1027 (1984) [hereinafter Storrs Lectures] (rejecting idea that "we can hear the genuine voice of the American people" when Congress speaks during periods of normal politics (emphasis in original)) Ackerman, Constitutional Politics/Constitutional Law, 99 YALE L.J. 453, 461-62 (1989) [hereinafter Constitutional Politics]; Amar, Philadelphia Revisited: Amending the Constitution Outside Article V, 55 U. CHI. L. REv, 1043, 79-87 (1988) (equation of legislature with "the People" is "largely a fake"). As even Alexander Bickel conceded, "the process of reflecting the will of a popular majority in the legislature is deflected by various inequalities of representation and by all sorts of institutional habits and characteristics." A. Bickel, The Least Dangerous Branch 18 (1962). 
Although most laws originate in a representative body, the constitutions of approximately half the states authorize lawmaking by the electorate itself. $^{3}$ Should the conflict between the lawmaker and judge be played out differently when the people express their preferences directly rather than through an agent? Among the tens of thousands of pages written on the role of courts in a democratic society, this question has received almost no attention. Judicial opinions resolving constitutional challenges to laws enacted by plebiscite seldom explicitly address the matter of the appropriate standard of review. The unspoken assumption, however, seems to be that the analysis need not vary as a result of the law's popular origin. The nearly three dozen Supreme Court cases reviewing ballot propositions contain scarcely a word on the subject. ${ }^{\mathbf{5}}$ The rare recognition that the law under attack originated with the electorate is most often followed by a boilerplate statement like Chief Justice Burger's in Citizens Against Rent Contral/Coalition for Fair Housing v. City of Berkeley: "It is irrelevant that the voters rather than a legislative body enacted [this law] because the

3. Ser infra note 22. Even in those states that do not provide for statewide initiatives or popular referenda, direct democracy usually exists in some form. See infra text accompanying notes 22-27.

4. There have been a scattering of student comments on the subject. By far the most thoughtful of these is Comment, Judicial Review of Laws Enacted by Popular Vole, 55 Wash. L. Rev. 175 (1979); see also Comment, Constitutional Constraints on Initiative and Referendum, 32 VAND. L. REv. 1143 (1979); $f$. Comment, Judicial Review of Initiatize Constitutional Amendments, 14 U.C. Davis L. REv. 461 (1980) (discussing judicial review of procedures for initiatives to amend state constitutions). In addition, a few law review articles with somewhat different focuses have addressed the question. See, e.g., Bell, The Referendum: Democracy's Barrier to Racial Equality, 54 WASH. L. REv. 1, 22-28 (1978). See also the comments of Laurence Tribe and Jesse Choper in J. Choper, Y. Kamisar \& L. Tribe, The Supreme Court: Trends and Developments (1981-82), at 242-43 (standard of review should not take into account whether law was enacted by legislature or directly by people).

5. Because the Court frequently makes no mention of the process by which state laws are adopted, the figure may in truth be higher than the one cited in the text. Cases in which the Court's opinion does note the popular origin of the challenged state statute or constitutional provision include Fisher v. City of Berkeley, 475 U.S. 260, 261 (1986); California v. Ramos, 463 U.S. 992, 995 n.4 (1983); Crawford v. Board of Education, 458 U.S. 527, 531-32 (1982); Washington v. Seattle School District No. 1, 458 U.S. 457, 462 (1982); Brockett v. Spokane Arcades, Inc., 454 U.S. 1022, 1023 (1981) (Burger, J., dissenting); Citizens Against Rent Control/Coalition for Fair Housing v. City of Berkeley, 454 U.S. 290, 292 (1981); Town of Lockport v. Citizens for Community Action at the Local Level, Inc., 430 U.S. 259, 262 (1977); City of Eastlake v. Forest City Enterprises, 426 U.S. 668, 670 (1976); Richardson v. Ramirez, 418 U.S. 24, 28 n.2 (1974); Lehnhausen v. Lake Shore Auto Parts Co., 410 U.S. 356, 357 (1973); Gordon v. Lance, 403 U.S. 1, 2 (1971); James v. Valtierra, 402 U.S. 137, 139 (1971); Hunter v. Erickson, 393 U.S. 385, 386 (1969); Epperson v. Arkansas, 393 U.S. 97, 109 n.17 (1968); Reitman v. Mulkey, 387 U.S. 369, 371 (1967); Jordan v. Silver, 381 U.S. 415 (1965); Lucas v. Forty-Fourth General Assembly of Colorado, 377 U.S. 713, 715 (1964); Scholle v. Hare, 369 U.S. 429, 433 (1962) (Harlan, J., dissenting); AFL v. American Sash \& Door, 335 U.S. 538, 539 (1949); Oyama v. California, 332 U.S. 633, 658-59 (1948) (Murphy, J., concurring) (describing "atmosphere heavy with race hatred" surrounding enactment of initiative); Asbury Hospital v. Cass County, 326 U.S. 207, 209 (1945); Columbus Gas \& Fuel Co. v. PUC, 292 U.S. 398, 399 (1934); Ex Parte La Prade, 289 U.S. 444, 452 (1933); Pierce v. Society of Sisters, 268 U.S. 510, 530 (1925); Porterfield v. Webb, 263 U.S. 225, 231 (1923); Hawke v. Smith, 253 U.S. 221, 224 (1920); Adams v Tanner, 244 U.S. 590, 591 (1917); State of Ohio ex rel. Davis v. Hildebrant, 241 U.S. 565, 566 (1916); Truax v. Raich, 239 U.S. 33, 35 (1915); Gity of Denver v. New York Trust Co., 229 U.S. 123, 125 (1913); Kiernan v. Portland, 223 U.S. 151, 152 (1912); and Pacific States Telephone \& Telegraph Co. v. Oregon, 223 U.S. 118, 119 (1912). 
voters may no more violate the Constitution by enacting a ballot measure than a legislative body may do so by enacting legislation."

Intuitively, Chief Justice Burger's position seems wrong. If the people are the sovereign from which all power originates, ${ }^{7}$ then why should their expression of will not carry more weight than the legislature's crude effort to approximate it? If the root difficulty of judicial review is its countermajoritarian nature, ${ }^{8}$ why does the argument for judicial intervention not abate as it becomes clearer what the majority prefers? This claim struck a responsive chord with Hugo Black. During the oral argument in Reitman v. Mulkey, ${ }^{9}$ then Solicitor General Thurgood Marshall called attention to the fact that California's authorization of discrimination in the private housing market had been enacted by voter initiative. "Wouldn't you have exactly the same argument," he was asked, if the provision "had been enacted by the Galifornia legislature?" "It's the same argument," Marshall replied, "I just have more force with this." "No," interjected Justice Black, "It seems to me you would have less. Because here, it's moving in the direction of letting the people of the State-the voters of the State-establish their policy, which is as near to a democracy as you can get."11

It is more than abstract theories of sovereignty and democracy, however, that give judicial review of voter lawmaking a different cast. A judicial decision striking down a voter effort also risks engendering a perception by the public itself that its will has been subverted. Neglecting voter ex-

6. 454 U.S. 290,295 (1981) (emphasis added); see also Lucas, 377 U.S. at 737 (that challenged legislative apportionment plan was approved by electorate held to be without Federal constitutional significance); Felix v. Milliken, 463 F. Supp. 1360, 1375 (1978) (constitutionality of initiative "should be assessed as though . . . enacted by legislature"). State court decisions reveal a similar tendency to treat legislation and voter enactments as though they were interchangeable. See, e.g., Wallace v. Zinman, 200 Cal. 585, 593, 254 P. 946, 949 (1927) (initiative measure has no greater strength or dignity than any other legislation).

7. See Eule, Temporal Limils on the Legislative Mandate: Entrenchment and Retroactivily, 1987 AM. B. Found. RES. J. 381, 394-96. As Akhil Amar persuasively demonstrates, however, sovereignty under the United States Constitution resides in the People of the United States as a whole rather than in the people of each state. See Amar, Of Sovereignty and Federalism, 96 YALE L.J. 1425 (1987). While the legislating electorate in a state may be regarded as sovereign for purposes of the state constitution, it cannot be so treated within the context of the Federal Constitution. See Amar, supra note 2 , at 1063 n.73. I shall return to this theme in later pages.

8. See A. Bickel, supra note 2 , at 16.

9. 387 U.S. 369 (1967).

10. Although Reitman involved a state constitutional initiative rather than a statutory initiative the thrust of this paper is equally applicable in both settings. See infra note 28.

11. 64 Landmark Briefs and Arguments of the Supreme Court of the United States: Constitutional Law 668 (P. Kurland \& G. Casper eds. 1975) [hereinafter Landmark Briefs]. Justice Black expressed similar sentiments in his majority opinion in James v. Valtierra, 402 U.S. 137,141 (1971) (provisions for referenda demonstrate "devotion to democracy"), and his dissent in Hunter v. Erickson, 393 U.S. 385, 397 (1969) (Black, J., dissenting). See also Legislature v. Deukmejian, 34 Cal. 3d 658, 683, 669 P.2d 17, 35 (1983) (Richardson, J., dissenting) (initiatives entitled to "z'ery special and very favored treatment" (emphasis in original)). 
pressions thus carries with it a measure of political discomfort unlike that associated with invalidating legislation. ${ }^{12}$

The thesis of this Article is that arguments for judicial restraint indeed play out differently when courts review the constitutionality of direct expressions of the electorate. My ultimate conclusion, however, is that judicial review of direct democracy frequently calls for less rather than more restraint. Admittedly, this proposition may seem even more counterintuitive than Chief Justice Burger's suggestion that the people's voice deserves no more sensitive a judicial ear than is accorded their representatives'. Direct democracy has a strong emotional pull cutting clear across the political spectrum. The Port Huron Statement, founding document of the Students for a Democratic Society, called for a shift from representative to "participatory democracy."13 Ralph Nader endorsed a constitutional amendment for a national initiative. ${ }^{14}$ Conservative politicians and think tanks trumpet the virtues of popular decision-making. ${ }^{15}$ Public opinion polls show widespread support for expanding the use of plebiscites. ${ }^{18}$ Small wonder that Professor Derrick Bell has warned that those who criticize direct democracy risk being labeled "reactionary, if not unAmerican,"17 and that public figures in states that provide for direct legis-

12. Former California Supreme Court Justice Joseph Grodin recently described his feelings as follows: "It is one thing for a court to tell a legislature that a statute it has adopted is unconstitutional; to tell that to the people of a state who have indicated their direct support for the measure through the ballot is another." J. Grodin, IN PuRsuit of Justice 105 (1989).

13. Students for a Democratic Society, Port Huron Statement (1962), reprinted in J. MILLER, Democracy is in THE STreets app. at 333 (1987).

14. Voter Initiatize Constitutional Amendment: Hearings on S.J. Res. 67 Before the Subcomm. on the Constitution of the Senate Comm. on the Judiciary, 95th Cong., 1st Sess. 90-102 (1977) [hereinafter Hearings] (testimony of Ralph Nader).

15. Sep, e.g., Hearings, supra note 14, at 22 (statement of Rep. Guy Vander Jagt); id. at 203 (statement on behalf of Liberty Lobby); J. KeMP, AN AMERICan Renaissance 189 (1979); P. MCGuigan, The Politics of Direct Democracy in the 1980s: Case Studies in Popular DeciSion Making 119-21 (1985).

16. Two-thirds of those questioned in a 1987 Gallup survey said that citizens ought to be able to vote directly on some state and local laws. See T. Cronin, Direct Democracy: The Politics of INITIATIVE, REFERENDUM, AND RECALl 79 (1989). A nationwide poll conducted by Cambridge Survey Research in 1977 found $57 \%$ in favor of a constitutional amendment for a national initiative with only $25 \%$ opposed. See Hearings, supra note 14, at 17. Gallup Polls in 1978 and 1981 similarly found support for a national initiative running better than two-to-one. See T. CronIN, supra, at 174-75. Nearly identical proportions of Republicans, Democrats, and Independents agreed that the initiative was a good idea, a result that George Gallup called "an unusual finding on any question of political significance." Hearings, supra note 14, at 646. David Magleby argues that closer examination of public opinion polls reveal that the extent of public support for direct democracy may be exaggerated. While those polled appear to favor plebiscites when the question is worded in general terms, more precise questioning exposes mixed feelings about the legislative role played by the electorate. D. Magleby, Dirfact Legislation: Voting on Ballot Propositions in the United States 7-14 (1984). Nonetheless, as one recent poll of California voters conducted by Common Cause and the University of Southern California's Institute of Politics and Government discovered, despite the fact that many people are critical of the state's initiative process and favor reforms, the overwhelming majority (71\%) are unwilling to see the system scrapped. See Wolinsky, Are Citizens Losing the Initiative?, L.A. Times, Oct. 7, 1988, at A1, col. 1.

17. Bell, supra note 4 , at 2 . 
lation uniformly refrain from urging elimination-or even substantial modification-of these provisions. ${ }^{18}$

This Article is not, however, a commentary on the wisdom or practicality of conducting initiatives or referenda at the state or national level. ${ }^{18} \mathrm{I}$ consider not whether we should continue to permit citizen lawmaking, but how courts should go about deciding challenges to the constitutionality of the voters' enactments. ${ }^{20}$ Despite the instinctive appeal of Hugo Black's view that the level of appropriate scrutiny ought to decline as democracy becomes more direct, I believe that a deeper consideration will reveal that he is 180 degrees off the mark.

\section{The SCope of Direct Democracy}

Several years ago I left my roots in the Northeast and moved to California. My well-traveled East Coast friends and apprehensive West Coast colleagues admirably prepared me for the culture shock that awaited. As a consequence of their efforts, earthquakes, orange-tinted hair, and mortgages resembling the national budget deficit were taken in stride. No one prepared me, however, for Election Day. Sometime in mid-October a massive booklet arrived in my mailbox. At first I thought it was the local phone directory. Closer examination revealed it to be a "Ballot Pamphlet" from California's Secretary of State. Its contents included a staggering array of bond acts, proposed constitutional amendments and statutory initiatives. The pamphlet contained the complete text of each ballot measure (some running over a dozen pages in print so small that a magnifying glass, if not a microscope, was required to read it), summaries prepared

18. See League of Women Voters of California, Initiative and Referendum in CaliFORNIA: A LEGACY LOST? 59 (1984) (no public figure in memory has suggested that initiative be eliminated or modified and none is likely soon to do so); Allen, The National Initiatize Proposal: $A$ Preliminary Analysis, 58 NEB. L. REv. 965, 1040 (1979) (there has never been serious effort to eliminate initiative in any state that has ever embraced $i t)$.

19. Compare Briffault, Distrust of Democracy (Book: Review), 63 TEx. L. REv. 1347 (1985) (direct legislation remedies some of legislature's shortcoming and complements legislative process) and Gillette, Plebiscites, Participation, and Collective Action in Local Groernment Law, 86 MIICH. L. REv. 930 (1988) (criticisms of plebiscites both understate capacity of participation and overstate capacity of legislative processes to serve public interest) with D. MAGLEBY, supra note 16 (process of direct legislation has fallen far short of original reformers' expectations) and Bell, supra note 4 (the more direct democracy becomes, the more it threatens unpopular minorities). On the desirability of a national initiative process, compare Allen, supra note 18 (favoring adoption of national initiative process) with Black, National Lawmaking by Initiative? Let's Think Twice, Hum. RTS., Fall 1979, at 28. For recent calls for increasing the degree of citizen participation, see B. BARBER, STRONG DEmocracy (1984); C. Pateman, Participation and Democratic Theory (1970); Frug, The City as A Legal Concept, 93 Harv. L. Rev. 1059 (1980); Lobel, The Meaning of Democracy: Representatite and Participatory Democracy in the New Nicaraguan Constitution, 49 U. PITT. L. REv. 823 (1988).

20. The issue of the appropriate standard for reviewing the substance of specific citizen legislation should be distinguished from the questions of whether a state's very use of the mechanisms of initiative or referendum violates the Constitution when (1) employed generally, see text accompanying notes 201-208, or (2) used selectively for issues disproportionately affecting politically unpopular minorities, see text accompanying notes 360-75. 
by the State's Attorney General, analyses by someone identified as the Legislative Analyst, arguments in favor of and in opposition to each measure written by a diverse group of persons chosen by some unexplained process, and rebuttals to both sets of arguments, often by yet a different group of mysteriously-selected "representative" voices. Even those able to make the major time commitment necessary to trudge through the opus-the 1988 version ran 159 pages-must have found the going tough. The propositions average over forty-five words per sentence, and recent studies suggest that only those with a reading level equivalent to that of a third-year college student could have comprehended the pamphlet. ${ }^{21}$

Just as I was struggling through the state ballot pamphlet and beginning to wonder how I had graduated law school with a reading level below that of a third-year college student, the postal service delivered another ballot pamphlet. This one was compiled by the Los Angeles City Clerk and contained text, summaries, arguments-pro and con-and rebuttals for approximately half-a-dozen city ballot measures. Although the pages were fewer-the 1988 version ran sixty-four pages-and smaller-eight and a half by five inches rather than eight and a half by eleven inches-and the print was a good deal larger, I was too dazed to exhibit the proper appreciation. By the time a third pamphlet arrived, a gift from the County Registrar-Recorder with information concerning the county measures, earthquakes were starting to look appealing.

While Californians' use of plebiscites may be exceptionally heavy, direct democracy is a national phenomenon. The twenty-six state constitutions that authorize voters to initiate legislation or to demand the referral of legislative enactments ${ }^{22}$ are but a small measure of its scope. Thirty-six

21. D. MAGLEBY, supra note 16 , at 138-39.

22. In 21 of these states, citizens may initiate and enact ordinary legislation (Alaska; Arizona; Arkansas; California; Colorado; Idaho; Maine; Massachusetts; Michigan; Missouri; Montana; Nebraska; Nevada; North Dakota; Ohio; Oklahoma; Oregon; South Dakota; Utah; Washington; and Wyoming). See infra Appendix A. In three additional states (Kentucky, Maryland, and New Mexico), as well as in all the 21 previously named, voters can require the legislature to refer enactments to the electorate for approval or rejection. Id. Finally, in two more states (Florida and Illinois) the voters' rights are limited to the initiation of state constitutional amendments (in Illinois the amendments may pertain only to the Legislative Article). The right to initiate a state constitutional amendment is enjoyed as well by the citizens of 15 of the states that allow statutory initiatives (Arizona, Arkansas, California, Colorado, Massachusetts, Michigan, Missouri, Montana, Nebraska, Nevada, North Dakota, Ohio, Oklahoma, Oregon and South Dakota). Id. The District of Columbia also provides for voter initiative and popular referendum. D.C. CoDE ANN. § 1-281 (1987).

The extent to which citizen lawmaking actually occurs varies considerably among the 26 states. Wyoming, which adopted the initiative in 1968, went 16 years without a single initiative qualifying for the ballot. See LeAGue of WoMEN Voters, supra note 18, at 89 . Five states, Arizona, California, Colorado, North Dakota, and Oregon, are at the other end of the spectrum, qualifying well over one hundred initiatives each between 1898 and 1979. See D. MAGLEBY, supra note 16, at 71. A state's historical tradition and political culture, rather than the stringency of the qualifying requirements, may be the most critical factor determining frequency of use. See Sirico, The Constitutionality of the Initiative and Referendum, 65 IowA L. REv. 637, 662 (1980). But see D. MagleBy, supra note 16, at 42 (states with lowest signature thresholds have highest number of measures reaching ballot). 
states provide for statewide statutory referenda in some form ${ }^{23}$ and every state but Delaware requires the approval of the electorate to amend the state constitution. ${ }^{24}$ Statewide initiatives and referenda, however, aicount for only about two percent of the nation's output of popular legislation. Plebiscites abound on the local level, even in a large number of the states that do not authorize them on a statewide basis. ${ }^{25}$

Direct democracy comes in a multitude of forms. ${ }^{26}$ Naturally, the general conclusions I offer here will have to be adapted to fit the structure of a particular state or municipality. The more immediate difficulty caused by the jurisdictional variations is one of terminology. Usage of terms is not uniform and the coining of my own may avoid some confusion. For purposes of this Article, I shall divide instances of direct democracy into two basic subgroups. The first I will call substitutive direct democracy; the second, complementary direct democracy.

Substitutive direct democracy is direct democracy in its purest current form. Here the voters can completely bypass the legislative and executive branches of government. Of course, in a true direct democracy there would be no legislature to displace, but no such form exists in the United States today. Thus, the states and municipalities that permit this kind of direct democracy have a primary representational form of governance but afford voters the opportunity to substitute plebiscites for the ordinary process of lawmaking. In order to exercise this option the voters neither need legislative permission nor legislative assistance. A measure may be placed on the ballot by securing a specified number of signatures-usually set at some percentage of the votes cast in the preceding general election-and the measure is enacted if a majority of the voters signify their approval. ${ }^{27}$

23. See infra Appendix A. In 24 of these states the voters themselves have the power to force the legislature to refer legislative enactments to the electorate. See supra note 22 . In the remaining states, referenda occur either because the legislature chooses to consult the electorate or because the state constitution mandates that legislation relating to certain issues be submitted to the voters before taking effect. Id. Fourteen states make no provision for statewide statutory referenda (Alabama, Connecticut, Delaware, Hawaii, Indiana, Louisiana, Minnesota, Mississippi, New Hampshire, South Carolina, Tennessee, Texas, Vermont, and West Virginia). Id.

24. See infra Appendix A. A discussion of Delaware's process of constitutional amendment appears in Eule, supra note 7, at 398-99.

25. One study estimates the national volume of local referenda at 10,000 to 15,000 annually. Hamilton, Direct Legislation: Some Implications of Open Housing Referenda, 64 AM. Pol. ScI. REv. 124, 125 (1970). In contrast the number of statewide referenda in a given year ranges from 50 to 350. See D. MAGleBY, supra note 16, app. C at 205-06.

Thirty-nine states permit or require plebiscites at the local level including several like Minnesota, Texas, and West Virginia that do not provide for them on a statewide basis. See Council of State Governments, The Book of THE STATEs 1980-81, at 26 n.c (initiatives); Referendums: A CoMParative Study of Practice and Theory 71-72 (D. Butler \& A. Ranney eds. 1978) [hereinafter REFERENDUMS] (referenda).

26. Spe LeAGue of WOMEN Voters, supra note 18, at 13-20 (describing variations among states); D. MAGLEBY, supra note 16, at 38-39 (Table 3.1).

27. In most cases a simple majority of those voting on the ballot measure is all that is required. A few states require something more. In Massachusetts, for example, a measure must also receive $30 \%$ of the vote of those who turn out for the election. No doubt these sorts of special requirements are responses to "voter dropoffs." Sometimes as many as $25 \%$ of those who turn out to vote for candidates 
Ordinarily, such a form of plebiscite is called an initiative. ${ }^{28}$ Initiatives, however, are often subclassified as direct or indirect. The process just described is generally referred to as a direct initiative. An indirect initiative, on the other hand, requires that the voters' petition be submitted to the legislature before the issue is placed on the ballot. The legislature has a specified period of time in which to enact the proposal. If the legislature fails to do so, the measure is sent to the voters. ${ }^{29}$ For purposes of my classification scheme it is largely irrelevant which form of the initiative is used, so long as the voters ultimately vote on the measure. If the legislature adopts an indirect initiative, the resulting law should be seen as a product of representative government, not direct democracy.$^{30}$ But, if the legislature rejects it, the ensuing voter effort must be considered substitutive. Since the legislature may not prevent the measure from being placed on the ballot, the voters still retain the ultimate right to displace completely the representational framework for lawmaking and substitute a direct one. The process simply takes a little longer..$^{31}$

fail to cast votes on the ballot measures. See D. MAGLEBy, supra note 16, at $46-47$. For a listing of the specific requirements for qualification and approval of statewide statutory initiatives, see CouncIL of State Governments, the BoOK of THE States, 1988-89, at 217 (Table 5.14) (hereinafter Book of THE States], and D. MaglebY, supra note 16, at 38-39 (Table 3.1). See also Lowenstein, Campaign Spending and Ballot Propositions: Recent Experience, Public Choice Theory and the First Amendment, 29 UCLA L. REv. 505, 514 n.25 (1982) (many local propositions require more than a simple majority for passage).

28. Substitutive direct democracy is not limited to statutory initiatives. Voters in seventeen states may also initiate amendments to the state constitution. See infra Appendix A. As with the statutory initiative, the electorate operates completely independent of the legislature, and no more than a majority vote is required for passage. Although the signature requirements for placing constitutional initiatives on the ballot are frequently greater than for statutory initiatives, see Comment, The Judician and Popular Democracy: Should Courts Review Ballot Measures Prior to Elections?, 53 FordHaM L. REV. 919, 927 n.36 (1985), the vote needed for ratification is usually the same, but see Nev. CoNST. art. XIX, $\S 2$ (voters must approve amendment twice).

Naturally, the fact that the voters enact a constitutional amendment rather than a statute effectively precludes the possibility of substantive judicial review under the state constitution. See Answer of the Justices, 377 N.E.2d 915, 916 n.2 (Mass. 1978) ("[I]t is difficult to comprehend how [a] . . . constitutional amendment can be 'unconstitutional' under [the state] Constitution."). Constitutional initiatives may, however, be challenged under the state constitution as procedurally defective or beyond the scope or subject matter of permissible voter amendments. See generally Fischer, Ballot Propositions: The Challenge of Dired Democracy to State Constitutional Jurisprudence, 11 Hastings Const. L.Q. 43, 50-59 (1983); Comment, Judicial Review of Initiative Constitutional Amendments, supra note 4 , at 468-84. Where a challenge is mounted under the Federal Constitution no consequences ought to flow from the nature of what has been enacted. The supremacy clause subjects state constitutions and statutes alike to the constraints of the United States Constitution. See Pruneyard Shopping Center v. Robins, 447 U.S. 74, 79 (1980) (state constitutional provision is "statute" within the meaning of Supreme Court's jurisdiction to review constitutionality of state "statute"); L. TRIBE, AMERICAN Constitutional LAw 647 n.27 (2d ed. 1988) ("The Supreme Court has never found it significant [under bill of attainder clause] that the challenged provision was part of the state's constitution rather than a simple enactment of its legislature."). What is crucial to my thesis is that the legislative process has been bypassed, not that a certain label has been affixed to the ballot measure.

29. See D. MAGLEBY, supra note 16, at 35-36. Thirteen states provide for direct initiatives only. Five states have indirect initiatives only. Three states have provisions for both. See infra Appendix A.

30. Admittedly, it is voter pressure that induces legislative passage, but this may be equally true where the initiative process has not yet been commenced-or in states where it is not even available.

31. My analysis here may be a bit too facile. While the legislature cannot prevent the proposition from appearing on the ballot (short of enactment), the legislative detour demanded by the indirect 
While substitutive direct democracy offers a stripped down version of lawmaking free from the constraints-and, as I shall argue, the safeguards-of the legislative framework, complementary direct democracy adds an additional tier. This form of direct democracy is commonly called a referendum because the legislation is referred to the electorate for ratification. ${ }^{32}$ Here the voters and the legislature must act in concert before a law may take effect. Legislative passage is prerequisite but inadequate: Without voter endorsement the legislative effort fails; without legislative passage the electorate has nothing to vote on.

Referenda come in three versions, ${ }^{33}$ differentiated by who or what prompts the referral. In the first, the so-called mandatory or compulsory referendum, the state constitution commands submission of certain legislative enactments to the electorate. This version is often used for debt authorization ${ }^{34}$ and is necessary in forty-nine states for legislatively initiated amendments to the state constitution. ${ }^{35}$ In the second version, often styled the voluntary referendum, the legislature is given the option to refer measures to the voters. ${ }^{36}$ In its final form, usually known as the popular referendum, citizens can petition to force a referral of a previously enacted-but not yet effective-legislative measure. ${ }^{37}$

Direct democracy, the conventional history tells us, was a response of the Progressive Reform movement to the widely perceived corruption and control of legislatures by corporate wealth. The Progressives' remedy curbed legislators by placing corrective power in the citizenry. ${ }^{38}$ Substitu-

initiative may afford opportunities for debate, deliberation, compromise, and amendment that the initiative process ordinarily lacks. See infra text accompanying notes 231-247.

32. The word "referendum" is, however, often used synonymously with "plebiscite" to refer to all ballot measures. See T. CRONIN, supra note 16, at 2; P. MCGuigan, supra note 15, at 25; Lowenstein, supra note 27 , at 508 n.4. As such it can encompass initiatives. See, e.g., Referendums, supra note 25 , at $23-24$.

33. Although there exists a fourth version of the referendum, the advisory referendum, I have omitted it from my discussion because it results in no enactment and is thus beyond the ambit of judicial review.

34. Sep Book of THE States, supra note 27, at 218-19 (Table 5.15) (listing 14 state constitutions that require referendum for debt authorization).

35. See infra Appendix A.

36. Fourteen states provide for voluntary submission by the legislature. See id. In some states only certain subject matters may be voluntarily referred. Others leave the scope entirely to legislative discretion.

37. Twenty-four states provide for popular referenda, see id., but the device is not used frequently, see T. CRONIN, supra note 16, at 197, perhaps due in part to the short time frame permitted for signature collection. See P. McGuigan, supra note 15 , at 28 . Scholarly treatments of direct democracy frequently lump the popular referendum with the initiative, see, e.g., D. MAGLEBY, supra note 16 , at 1 , no doubt because both originate with the voters. This is a little too simplistic. A popular referendum cannot result in the enactment of law unless a legislature has first passed on the measure favorably. Where the voters confirm the legislative choice, the popular referendum is more complementary than substitutive. It is when popular referenda repeal legislative efforts that they most resemble substitutive plebiscites. This, however, is a claim that might be made about any repeal by referenda. It is not unique to the popular referendum. See infra Part III.B.

38. See, e.g., V.O. Key \& W. Crouch, The InItiative and Referendum in California (1939); L. Tallian, Direct Democracy: An Historical Analysis of the Initiative, Referendum and Recali. Process 34-44 (1977); J. Zimmerman, Participatory Democracy 35, 69 
tive plebiscites, by circumventing the legislative framework, rectify corruption that impedes legislation. In contrast, the Progressives directed complementary plebiscites against corruption that produces legislation. Toward this end, the reformers added a new layer to the lawmaking process. Thus, the two Progressive reforms simultaneously made it easier and more difficult to enact laws. One dismantled the system of checks and balances. The other augmented it. A consideration of judicial review of direct democracy must be sensitive to the difference. The bulk of my analysis in Part II focuses on the substitutive form of direct democracy. I consider the theory's peculiar implications for the complementary form in Part III.B.

\section{Rethinking the Counter-Majoritarian Difficulty}

\section{A. Does Direct Democracy Accurately Reflect Majority Will?}

Majoritarian democracy, we constantly are reminded, is the core of our constitutional system. If so, the plebiscite certainly seems to have a strong claim to being its most treasured instrument. Proponents of direct democracy regularly champion the plebiscite as the means by which to hear the genuine voice of the people. Oh sure, it would be nice to have town meetings, New England style. But our sheer numbers make that unfeasible, even if most of us could be counted upon not to show up. The next best way to gauge the sentiments of the citizenry would seem to be a plebiscite.

(1986). An alternative story is available. Some historians have revealed a darker side to the Progressive Reform movement. Impulse for reform seldom originated with working-class or immigrant groups. Instead, those who spearheaded it frequently were distinctly middle-class, see R. HoFStadter, The Age of Reform 131-271 (1955), or even upper-class, see S. Hays, American PoLitical History as Social ANal.ysis 209-14 (1980). Reformers may have been less interested in expanding popular participation in the governmental process than in grabbing a piece of the pie for themselves. As historian Leland Baldwin has written, reformers came in different guises. Sometimes they were "practical idealists, sometimes disgruntled politicians or business elements seeking to overthrow the old regime, sometimes aspiring young men ready to seize any entree to power." L. BALDwin, The Stream of American History 381 (1952); see also S. Hays, supra, at 215 ("The movement for reform in municipal government . . . constituted an attempt by upper-class . . . and large business groups to take formal political power from the previously dominant lower- and middleclass elements."); Davidson \& Korbel, At-Large Elections and Minority Group Representation: A Repxamination of Historical and Contemporary Evidence, in Minority Vote Dilution 78 (C. Davidson ed. 1984) ("many [Progressive] reformers . . . [sought] to wrest control of municipalities from laboring classes and ethnic minorities"). There is evidence that expansion of direct democracy often was designed more as a political tactic to secure immediate victory against the existing political machine than as an alternative system of sustained decision-making. S. HAYS, supra, at 228-29. The reformers might have claimed to be neutralizing the powers of the special interests but they more often than not backed direct democracy devices principally because they favored alternative policy outcomes. See T. Cronin, supra note 16, at 58-59. It would be foolhardy, of course, to ignore the geographical variations in the origins and motivations of reform. California's Progressive effort was largely precipitated by concern over the monopolistic power of the Southern Pacific Railroad, see G. Mowry, The California Progressives (1951), and, in Wisconsin, Progressive support tended to come from the poor rural portions of the state, see Wyman, Middle-Class Voters and Progressive Reform: The Conflict of Class and Culture, 68 AM. PoL. SCI. Rev. 488-504 (1974). It might do well to recognize, however, that some of the special interest control that often characterizes direct democracy, see infra note 246 , may not have been an unintended by-product. 
Compared to direct democracy, the legislature seems far removed from majority preferences. When we vote for candidates it is often difficult to know exactly what we are saying. And even if representatives perfectly mirrored the people who voted for them, inequalities of representation and all sorts of institutional practices prevent accurate legislative expressions of popular will. ${ }^{39}$ When, on the other hand, we are asked to register our views on a single issue, the assertion that the result reflects the majority's preference has great force.40

In Part II.B, I shall argue that this quest for more accurate aggregation of majority will is misguided. The gap between the will of the majority and the voice of the legislature, it turns out, is there by constitutional design. But even accepting, for the moment, the underlying premise that the identification of majoritarian preferences is the central mission of American government, the accuracy of the plebiscite as a measuring stick is not beyond questioning. In more ways than we might acknowledge initially, popular votes do a flawed job of discovering what "the people" really want. To begin with, less than half of the adult American population regularly vote-a level of electoral participation that is by far the lowest found in any Western country. ${ }^{11}$ These are scarcely ideal conditions for gauging "the people's" sentiments on any specific issue. What is worse, significant numbers of those who vote for candidates at the top of the ballot fail to follow through ("dropoff") when it comes to voting on initiatives and referenda. ${ }^{42}$ We legitimately may question whether the full

39. See A. BICKel, supra note 2, at 18; Chemerinsky, The Supreme Court 1988 Term-Foreword: The Vanishing Constitution, 103 Hakv. L. REv. 43, 79 (1989).

40. See Sunstein, Legal Interference with Private Preferences, 53 U. CHI. L. Rev. 1129, 1144

(1986) (there is good reason to believe that referendum reflects majority's preferences).

41. See W. Burnham, The Current Grisis in American Polrtics 11, 161 n.1 (1982). According to Burnham, about $44 \%$ of the national electorate are "core" voters, about $16 \%$ are "peripheral," and the remaining $40 \%$ are outside the political system altogether. $I d$. at 46. On the "disappearance" of the American voter, see generally Burnham's historical narrative at 121-65. According to figures compiled by the Bureau of the Census, there were nearly 170,000,000 Americans of voting age in 1984. Less than $102,000,000$ reported that they had voted in that year's presidential election. See U.S. Bureau of the Census, Department of Commerce, "Characteristics of Voters in 1984 Presidential Election," reported in 1989 Information Please Almanac 617. These data exaggerate actual participation because official tabulations of the vote suggest substantial overreporting. Id. (Reagan and Mondale totaled only $92,000,000$ votes). Abstention, of course, runs even higher in off-year elections.

42. Spe T. CRONIN, supra note 16, at 67 (5 to 15 percent dropoff in voter participation is common in state issue elections); D. MAGLEBY, supra note 16, at 100 (on average 15 to 18 percent of those who turn out do not vote on statewide propositions); Gillette, supra note 19, at 969 n.136 (anecdotal evidence on dropoff in Massachusetts in 1984 and 1986). There is some dispute over the methodology used to measure voter "dropoff" (the proportion of voters who cast ballots but do not vote on a particular measure). Magleby compares the rate of voting on ballot measures with the rate of voting for the candidate contests with the highest turnouts-like gubernatorial elections. Others have argued that a more appropriate standard of comparison is voter participation in congressional and state legislative races. Judged by this standard, dropoff rates diminish markedly. See Briffault, supra note 19, at 1358-59. In addition, it appears that dropoffs may disappear altogether for wellpublicized or hotly contested ballot measures. See LEAGUe OF WOMEN VOTERS, supra note 18, at 56 (in California primary elections from 1968 to 1982, initiative or referendum which drew highest number of votes usually outpolled candidates at top of ballot); T. CRONIN, supra note 16, at 3 (more people voted on California's famous Proposition 13 than in same day's gubernatorial primaries); see 
citizenry share the preferences of the subgroup who actually vote on the ballot proposition.

Two responses might be offered. First, those who cast votes may be representative of those who stay home. It is by no means clear, however, that nonvoters would be divided in the same proportion as voters. Citizens of higher social and economic status are far more heavily represented among voters than among those who abstain, a class skew virtually unparalleled in any other political system conducting free elections. ${ }^{43}$ This bias is exaggerated by the nature of who "drops-off" for ballot measure voting. Compared with voters generally, people who typically vote on propositions are disproportionately well-educated, affluent, and white. ${ }^{44}$ Minorities, the poor, and the uneducated are thus doubly underrepresented in the plebiscite. They are both less likely to turn out and less likely to vote on propositions if they do.

A second response might be that of estoppel. As the pre-election ads used to proclaim, "Vote and the choice is yours. Don't vote and the choice is theirs." In effect, those who choose to stay home are deemed to have given their proxies to those who go to the polls. This argument, however, enjoys diminished force if we have built obstacles into the process that make ballot measures inaccessible to certain groups. As David Magleby suggests, voters with less education rely more on political parties for voting cues. When asked to vote on complex and technical issues, they are less able to translate their political preferences into votes. ${ }^{45} \mathrm{My}$ own expe-

also B. Zisk, Money, Media and The Grass Roots 69, 74, 80 (1987) (tables breaking down voter dropoff by issue).

43. Sie W. Burnham, supra note 41 , at 11,121 ; S. Verba \& N. Nie, Participation in America: Political Democracy and Social Equality 125 (1972). In a 1976 survey of the Bureau of the Census, $30 \%$ of people in lower working-class occupations reported that they had never voted. Among white males of the propertied middle class the figure was $6 \%$. See id. at 123-24. See gemerally R. WOLFINGER \& S. ROSENSTONE, Who Votes (1980); Bureau of the Census, supra note 41, at 617 (in 1984 Presidential election $61 \%$ of employed voted as against $44 \%$ of unemployed; $79 \%$ of those with 16 or more years of education voted as against $44 \%$ of those with 11 or fewer years). On minority underrepresentation among voters, see generally Morris, Black Electoral Participation and the Distribution of Public Benefits, in Minority Vote Dilution 273-77 (C. Davidson ed. 1984).

44. See D. MAgleby, supra note 16, at 106-11. A 1968 survey found that while $27 \%$ of those who voted for candidates had some college education, this group constituted $35 \%$ of those voting on ballot issues; middle or upper class voters made up $45 \%$ of those voting on candidates, but $52 \%$ of those voting on ballot issues; while whites constituted $87 \%$ of those voting for candidates, they made up $92 \%$ of those who voted on ballot issues. See T. Cronin, supra note 16, at 76 (Table 4.4).

45. D. MAGLEBY, supra note 16, at 111 . Not surprisingly, a 1976 Massachusetts survey revealed that persons in the lowest income category were the most likely to state that they could not vote on a proposition because it was too long and they were unable to assess what a yes or no vote would mean. Id. at 116; se' also T. CRONIN, supra note 16, at 75 (because ballot-measure democracy requires voters who can digest and evaluate sophisticated information, it sometimes works to disfranchise certain kinds of voters). For a general argument that widespread nonparticipation is inappropriately attributed to the indifference and shiftlessness of the people, see E. SCHATTSCHNEIDER, THE SEMIsovereign PEople 97-113 (1960) (nonvoting caused by exclusion of people by extralegal process, by social processes, and by political system's organization and structure). See also Morris, supra note 43, at 275-77 (examining factors that contribute to low voter turnout among blacks: history of subordination and deliberate exclusion from politics; socioeconomic and psychological characteristics of black population; structural or procedural arrangements that discourage voting; leadership styles within 
rience in attempting to understand the ballot pamphlets, let alone the propositions they seek to elucidate, indicates that barriers are significant.

Considering the complexity and obtuseness of some measures, it's a wonder that anyone knows what he or she is voting on. Not surprisingly, a recent poll of voters revealed that only fifteen percent of those surveyed felt that they consistently knew enough about initiative measures to make a wise decision. ${ }^{46}$ And here, the direct democracy enthusiasts encounter their second problem. If the voters are unclear, ignorant or mistaken about what their vote signifies, then we ought to be wary of attributing majority support to the prevailing position. Because each individual has only a minor effect on political outcomes decided by majorities, voters have little incentive to become well informed. ${ }^{47}$ Those willing to invest the time will find the deck stacked against them. The propositions themselves tend to be lengthy, complex, technical, carelessly phrased, and ambiguous. They cross-reference other statutes and use legal terms of art beyond the ken of the ordinary voter. It is hard to take issue with those who conclude that the measures are accessible only to those with substantial college education. ${ }^{48}$ Because political parties seldom take a stand on ballot measures, external cues are more difficult to come by than in candidate elections. To compound matters, a ballot is rarely limited to a single measure. The ballot that greeted me when I entered the voting booth this past year contained twenty-nine statewide measures, ${ }^{48}$ six citywide propositions, and a

black communities).

46. Another $37 \%$ claimed to know enough about the issues involved to make a wise decision on ballot measures "most" of the time. The remaining $47 \%$ admitted to confusion on a regular basis. See Joint Project of the USC Institute of Politics and Government \& Common Cause (1985) (on file with author). Similar voter perceptions were detected in an earlier mail survey of four western states. Thus, $41 \%$ of Arizona voters surveyed "strongly agreed" that initiative and referendum measures on the ballot were "so complicated that one can't understand what is going on" with $33 \%$ agreeing "somewhat." In Colorado, $23 \%$ strongly agreed and 36\% agreed somewhat. In Oregon, the figures were $20 \%$ and $40 \%$ and in Washington, $18 \%$ and $34 \%$. See T. CRONIN, supra nate 16 , at 74 (citing R. Benedict \& L. Holland, Initiatives and Referenda in the Western United States, 1976-1980: Some Implications for a National Initiative? 40 (unpublished paper presented at the American Political Science Association annual meeting, Washington, D.C., August 1980)).

47. Sep A. Downs, An Economic Theory of Democracy (1956); Becker, A Theory of Conpetition Among Pressure Groups for Political Influence, 98 Q.J. Econ. 371, 392 (1983). This is particularly so in ballot issue elections where the "information costs" are even higher than in candidate elections. See T. Cronin, supra note 16, at 67. It may be, however, that low incentives lead most voters to refrain from voting altogether. See Gillette, supra note 19, at 969 (consumption benefits explanation of voting suggests that individuals with little interest in outcome of ballot proposition are unlikely to vote).

48. David Magleby has applied several academic readability formulas, measuring word difficulty, sentence length, complexity, and conceptual difficulty, to the short ballot summaries provided voters in California, Massachusetts, Oregon, and Rhode Island. According to Magleby, the summaries-presumably designed to aid voter understanding-themselves were readable only at the fifteenth grade level (third year of college) in Massachusetts and Rhode Island and at the eighteenth grade level (bachelor's degree plus two additional years) in California and Oregon. Magleby concludes that, judged solely by formal schooling, less than one-fifth the adults in these four states have the capacity to read and understand the actual ballot question and description. D. MAGLEBY, supra note 16, at 118-19.

49. Two authors have computed that, from 1911 to 1967 , there were an average of 22 statewide propositions on the California ballot every general election. See Wolfinger \& Greenstein, The Repeal 
countywide bond issue. Such overloads are guaranteed to so strain the voters' capacity for education as virtually to ensure decisions inconsistent with their own desires. To be sure, few jurisdictions can match the Los Angeles ballot (a fact for which you all should be grateful), but recent years have shown a proliferation of statewide measures throughout the nation. The 230 that appeared on the November 1988 ballot in a total of 41 states included the greatest number of initiatives and popular referenda placed before voters in half a century. ${ }^{50}$

Proponents and opponents of the ballot measures do little to assist voter understanding. Indeed, quite to the contrary, the motivating factor behind their efforts often seems to be to confuse the voter about the significance of a "yes" or "no" vote. Illustrations of deceptive advertising and sloganeering abound. ${ }^{51}$ This past year saw the tobacco industry spending twentythree million dollars in an effort to defeat an initiative intended to raise cigarette taxes. The industry ads labelled it "the first initiative which actually creates crime" (apparently on the bizarre theory, often not revealed in the billboards and television commercials, that higher tobacco taxes would encourage cigarette smuggling). Although the initiative ultimately passed, the deceptive ads contributed to a reduction in voter support from the seventy-five percent who favored it in a pre-ad poll to the fifty-eight percent who ultimately voted in favor. ${ }^{52}$

A recent innovation in obfuscation has been the placement of competing propositions on the ballot, leaving voters completely baffled about which one does what. Perhaps the boldest effort at using this new tactic was engineered by Occidental Petroleum. The Los Angeles City Council had entered into a contract with Occidental giving the company the right to drill for oil beneath one of the city's coastal communities. Some concerned citizens collected signatures for an initiative (Proposition $O$ ) designed to bar the drilling. Occidental qualified a competing initiative (Proposition P) which incredibly appeared to oppose offshore drilling. Only the most perceptive of readers could grasp the hidden intent of Occidental's effort-to mandate onshore drilling. Occidental then compounded its deception by advertising Proposition $\mathrm{P}$ as environmental legislation and entitling it "The Los Angeles Public Protection, Coastal Protection, and Energy Resources Initiative." It enlisted a former Governor, Edmund "Pat" Brown, to write a letter to the voters. Brown urged the defeat of

of Fair Housing in California: An Analysis of Referendum Voting, 62 AM. PoL. ScI. REv. 753, 767 n.40 (1968).

50. St' 9 InItiative and Referendum RePORT No. 10, at 15, 18 (Dec. 1988) [hereinafter Initiative and Referendum Report]; see also D. Schmidt, Citizen Lawmaking 24 (1989) (charting rise of initiative use).

51. See generally Lowenstein, supra note 27 , for a host of outrageous examples. Spe also LEAGUE OF WOMEN VOTERS, supra note 18, at 110-11.

52. Si' Wolinsky, supra note 16, at 3; L.A. Times, Nov. 10, 1988, at 26, col. 3; Initiative AND Referendum: The Power of the People! 6-7 (Winter 1989). 
Proposition $O$ because, unlike Proposition $P$, it "contains not a single word in opposition to offshore oil drilling." A legal effort to strike Occidental's measure from the ballot as fraudulent was denied by a state court judge, who unwittingly damned the entire Galifornia process of direct democracy by concluding that Proposition $\mathrm{P}$ was "probably no more misleading than any other initiative." 53 Any reader confused by this alphabetical parade and forced to refer back to the onset of this paragraph to discover whose initiative was Proposition $O$ and whose was $P$, is experiencing but a small measure of the voters' bewilderment.

Frequently, voter confusion results simply in a decision to forego voting on the ballot measure. ${ }^{54}$ On other occasions, however, it leads voters to vote "incorrectly" - contrary to their own desires. Studies of voting on propositions generally reveal a significant percentage of voters casting ballots at variance with their stated policy preferences. Estimates of this number generally run from ten to fifteen percent, although occasionally the figures rise much higher. ${ }^{55}$ Sometimes incorrect voting is attributable to the wording of the proposition. In a 1980 plebiscite on a local rent control ordinance those desiring to retain rent control were required to vote against the measure. Over three-fourths of the voters questioned in exit surveys did not match up their views on rent control with their vote: on the measure. One quarter favoring rent control incorrectly voted yes while one half opposing it erroneously cast a negative vote. ${ }^{56}$ More often, the complexity of the issue or deceptive campaigns produce the disparity between desire and vote.

This does not mean that every-or even most-plebiscites are inaccurate reflectors of the desires of those who vote. The extent of incorrect voting depends on the nature of the issue and the campaign waged. Fo: example, the 1964 repeal of fair housing legislation and the 1978 tax revolt in California undoubtedly were fair indicators of public sentiment. ${ }^{.77}$

53. See Palisadian Post, July 28, 1988, at 1, col. 2. Former Governor Brown's letter is on file with the author. Occidental's campaign unfortunately is part of a rich tradition of seeking to dupe voters into believing that environmental efforts are anti-conservationist. See, e.g., Lowenstein, supra note 27 , at $529-30$.

54. In a recent USC-Common Cause poll of California voters, supra note $46,68 \%$ of those surveyed asserted that they would not vote on ballot measures about which they felt ignorant. If those polled are being truthful, one has to wonder why "voter dropoffs" on ballot measures are not much higher than have been reported, see supra note 42 , given the large number that confess ignorance, see supra note 46.

55. See, e.g., Mueller, Voting on the Propositions: Ballot Patterns and Historical Trends in Califorria, 63 AM. PoL. Scr. REv. 1197, 1202-03 (1969) (60\% who voted on lottery proposition marked ballot capriciously); D. Anderson, Voting and Misvoting on the Ohio Election Day Registration Referendum 13 (unpublished paper presented to the Ohio Association of Economists and Political Scientists, March 10, 1979) (15\% of voters on this Ohio referendum voted at variance with their stated position), cited in D. MAGLEBy, supra note 16, at 142-43; D. Hensler \& C. Hensler, Evaluating Nuclear Power: Voter Choice on the California Nuclear Energy Initiative 106 (1979) (Rand Corporation survey) (14\% of sample interviewed voted contrary to their stated intentions), cited in $\mathrm{T}$. Cronin, supra note 16 , at 74 .

56. See D. MaglebY, supra note 16 , at $143-44$.

57. Sep Wolfinger \& Greenstein, supra note 49 , at 754-58 (voting on repeal of California's fair 
Even considerable confusion need not necessarily undermine the accuracy of ballot voting as a gauge of majority preferences. The margin of victory or defeat may exceed the number of those who vote incorrectly or the confused voters on either side of the issue may balance each other out. Further, if the conventional wisdom that confused voters tend to vote "no" is accurate, ${ }^{88}$ incorrect votes cast by those who recognize their own confusion will lead more frequently to false negatives (propositions defeated even though a majority of those voting really favored them) than false positives (propositions passed despite majority opposition). Nonetheless, the possibility that a successful ballot measure may fail to reflect the will of the majority because of the confusion of some who voted for it can not be ignored. ${ }^{58}$

Even if voters on ballot measures were representative of the general population-as they most assuredly are not-and even if votes were cast consistent with preferences-which a good deal of them do not appear to be-it simply may not be possible to assess majority will on the basis of plebiscitary results.

Take the following illustration: A city council elects to construct a drug rehabilitation facility in one of the city's three residential neighborhoods. A referendum is placed on the ballot which designates neighborhood $\mathrm{A}$ as the site. Some citizens of neighborhood A gather signatures for an initiative to preclude placement of such a facility in any residential area. Although a majority of the citizens of neighborhoods $B$ and $C$ favor the initiative, the second choice of most is that it be built in somebody else's backyard. Accordingly, both ballot measures pass. Furthermore, it is equally clear that the council's referendum would have passed just the same if the designated community had been neighborhood B or C. The majority, therefore, "desires" to bar drug rehabilitation facilities from every residential community - and to authorize their placement in any such community. The possibility of voting paradoxes such as this ${ }^{60}$ signifi-

housing legislation accurately reflected underlying attitudes); T. CRONIN, supra note 16, at 87 (California voters understood Proposition 13 property tax relief measure).

58. See Briffault, supra note 19 , at 1356 (lack of information about initiative proposal leads voters to vote negative); Comment, The California Initiatize Process: A Suggestion for Reform, $48 \mathrm{~S}$. CAL. L. REv. 922, 935 (1975) (campaign managers for opponents of initiative measures often attempt to confuse the voters, relying on political maxim "when in doubt, the electorate votes 'no" "); see also Joint Project, supra note 46 (voters polled reported that when they lack knowledge they are more likely to vote "No" than "Yes"). But see B. ZISK, supra note 42, at 170 ("I do not find strong support for the assertion that the confused voter votes "no." "); Lowenstein, supra note 27, at 551-56 (theory that confused or uncertain voter will resolve doubts by voting "no" is superficial and incomplete).

59. Daniel Lowenstein's extensive study of ballot campaigns dominated by "one-sided spending" spreading deceptive, superficial and irrelevant messages reveals that the result in certain of these elections "failed to reflect the will of the majority." Lowenstein, supra note 27, at 570 . Nearly all of Professor Lowenstein's examples, however, are false negatives-ballot measures that failed in spite of apparent majority support.

60. By the term "voting paradox" I mean broadly the coexistence of coherent individual valuations and a collectively incoherent choice. Voting paradoxes may occur as a result of cycling majorities, strategic voting, or agenda manipulation. See generally D. BLACK, THE THEORY OF CoMMITTEES 
cantly cloud the meaning of popular voting as a measure of majority preference. ${ }^{61}$

Of course, the application of these social choice critiques to direct democracy might prove too much, for no reasonably fair method of combining individual preferences can avoid the possibility of paradoxical results. ${ }^{62}$ Thus, it may be impossible to reflect accurately such a thing as the will of the majority. ${ }^{63}$ If so, plebiscites may not be uniquely disabled in their ability to express popular will. Any form of collective preference may yield unstable majorities and ambiguous results. This general fallibility of voting systems has induced Glayton Gillette to assert that "it is unclear that the problem [of aggregating preferences] affects participatory processes more than representative ones." assess his claim. Legislatures have a variety of structures, rules, and norms to ameliorate voting paradoxes. ${ }^{65}$ Admittedly, some of these devices are merely arbitrary tools for breaking majority cycles, ${ }^{66}$ but one must not discount the impact of deliberation and the opportunities for compromise and amendment. Legislators may agree to debate until one side convinces the other ${ }^{67}$ or until someone offers up a new alternative which a majority is willing to embrace as the body's preference. Deliberation can even lead to redefinition of the issue. In contrast, the rigidity of plebiscites may enhance the possibility of a skewed picture of majority will. Plebiscites offer only binary choices, but the set of solutions to a given problem is seldom

AND ElECTIONS (1958). An "unstable majority" is present where there exists a group of voters with the joint power to overturn it in favor of an alternative outcome that they like more. See generally Schwartz, The Unizersal-Instability Theorem, 37 PuB. CHOICE 487 (1981). A result is "amibiguous" where a different profile of preferences might have been obtained by using a different rule of aggregation. See Coleman \& Ferejohn, Democracy and Social Choice, 97 ErHics 11 (1986). Concrete evidence of paradoxical outcomes, unstable majorities or ambiguous results are difficult to isolate. When inconsistent results occur in successive elections, we are likely to attribute them to "changed preferences." On those occasions when conflicting choices emerge from simultaneously presented ballot measures, we tend to blame voter confusion.

61. See W. Riker, Liberalism Against Populism: A Confrontation Between the Theory of Democracy and THE Theory of Social Choice (1982). But see Coleman \& Ferejohn, supra note 60, at 22-24 (Riker overstates implications of instability results of social choice); Cohen, An Epistemic Conception of Democracy, 97 ErHics 26, 29 (1986) ("judgments of majorities, made under suitable conditions, provide a reasonable, although imperfect procedure for determining the general will").

62. See K. Arrow, Social Ghoice and Individual Values (2d ed. 1963).

63. See W. RIKER, supra note 61, at 137 (Arrow's Theorem may lead us to suspect that no such thing as "public interest" exists, aside from subjective-and hence dubious-claims of self-proclaimed saviors); L. TRIBE, supra note 28, at 12 n.6 (given Arrow's Theorem, one may deny that there exists any meaningful sense in which any process can even hope to "reflect" the will of majority).

64. Gillette, supra note 19, at 933. A similar assumption of the parity of the problem in the two settings appears in Amar, supra note 2, at 1080 (if social choice critiques destroy the idea of rational majoritarian legislature, they can equally be deployed to destroy idea of rational majoritarian polity); see also Coleman \& Ferejohn, supra note 60, at 8-9, 24 (1986) (instability and ambiguity do not alone provide reason for preferring representative democracy over direct democracy).

65. See Farber \& Frickey, The Jurisprudence of Public Choice, 65 TEX. L. REv. 873, 901-06

(1987) (Arrow's Theorem may have little direct relevance to legislatures because structures, rules, and norms prevent cycling majorities).

66. But see $i d$. at 903 (suggesting that many rules themselves have normative value).

67. Id. 
so limited. The fact that we restrict ourselves to two alternatives should not obscure the fact that we start off with many more. ${ }^{68}$ Further, limited access to the ballot may provide greater opportunities for agenda manipulation by initiative sponsors, enabling them to achieve equilibria not reflective of majority tastes. ${ }^{88}$

In the end, enumerating the plebiscite's flaws in expressing majority preferences can carry us only so far. Regardless of the many ways in which plebiscites garble the message of majority will, it would be difficult to argue convincingly that legislatures convey it more clearly..$^{70}$ Plebiscites seek to aggregate the preferences of the people. Legislative voting aggregates only the preferences of the representatives. To be sure, these representatives often purport to speak on behalf of their constituents, but it is fanciful to equate the two. If our goal is to assess majority will, the legislature appears to start at a distinct disadvantage. Even if it does better than plebiscites at aggregating individual preferences, its collective judgment is still one large step away from reflecting popular will. ${ }^{\mathbf{1 1}}$

On the other hand, the criticisms I have canvassed take a good deal of the wind out of direct democracy's sails. The core of the plebiscite's claim for judicial deference is its superior ability to convey the majority's viewpoint. This enhanced capacity to speak on behalf of the people is what

68. Ser W. Riker, supra note 61 , at 41 .

69. Id. at 169-95 (agenda manipulation often enforces equilibrium that majority tastes would not allow). Because it is extremely rare for binary choices to occur naturally, id. at 59 , those who control the agenda can strategically reduce the alternatives offered, $i d$. at 137 . In the example used above, a group favoring the placement of the drug rehabilitation facility in a residential neighborhood would frame the choice as between neighborhood $A$ on the one hand and neighborhoods $B$ and $C$ on the other. In this way they might attain victory-largely as a result of agenda manipulation-even though the first choice of a majority of voters was to confine such facilities to non-residential areas. Such an election tells us at most which alternative wins. It does not tells us that the winner would also have been chosen over another alternative with a better claim to be the social choice. Id. at 238 .

70. Sex generally Riker \& Weingast, Constitutional Regulation of Legislatize Choice: The Politial Consequences of Judicial Deference to Legislatures, 74 VA. L. REv. 373 (1988) (notion that legislative action represents popular will is fundamentally unsound). One may seriously wonder, however, whether, in certain instances, legislatures do not do better at ascertaining majority will than the plebiscite. This argument, of course, is dependent on accepting the objective existence of a "majority will" outside the revealed preferences of voters. If one is willing to reject the equivalence of actual and revealed preferences, it may well be that legislators occasionally have a better shot at discovering the actual preferences of the citizenry than does polling an advertising-manipulated, class-biased subgroup of the people on a nonamendable, binary choice proposition.

71. The aggregation difficulties associated with direct and representative democracy can be compared in a quite different way. Rather than contrasting how voters and legislative bodies fare in reflecting majority will, one might compare the aggregation of voters' preferences on ballot issues with the aggregation of their candidate selections. If the voters are unable to act in a meaningful sense in expressing their will on plebiscites, how can their election of officials be any more "representative"? Sir Coleman \& Ferejohn, supra note 60, at 21 (if outcomes of social choices are ambiguous and unstable, we cannot expect officials to take account of such signals in deciding how to behave). William Riker, while conceding that the aggregation problems in both these settings are similar, contends that the consequences are strikingly different. The point of plebiscites is to uncover the general will. In contrast, Riker argues, all that voting for officials has to do is permit the people to get rid of their rulers-an intermittent, sometimes random, even perverse popular veto. Elections for representatives are therefore unembarrassed by their failure to reveal a coherent popular will. W. RIKER, supra note 61 , at $241-46$. 
Justice Black was talking about when he called the ballot proposition "as near to a democracy as you can get." If the relationship between voter expressions and the majority's true desires is clouded by the functional disfranchisement of the lower classes, the confused, manipulated, and deceived quality of the votes cast, and the incoherence of the resulting aggregation, then direct democracy's edge over representative government is not as great as it first appeared ${ }^{72}$-even under a constitution that gives pre-eminent importance to unchecked majority rule. As it turns out, however, the United States does not have such a constitution.

\section{B. The Constitutional Filtering of Majority Will}

If the Constitution's Framers were keen on majority rule, they certainly had a bizarre manner of demonstrating their affection. The Federalist No. 10 hardly qualifies as an ode to the virtues of simple majoritarianism. On the contrary, it may be the ultimate in "Dear John" letters, addressed to transient majorities wherever they might be found. To be sure, Madison directs his venom at the threat of factions, "whether amounting to a majority or minority of the whole," restrained "by regular vote." Minority factions might "clog the administration," and "convulse the society," but they would "be unable to execute ... [their] violence under the forms of the Constitution." "74 Majority factions were far more to be feared, willing as they might be to sacrifice "the public good and the rights of other citizens" to their "ruling passion or interest." united by a common interest," wrote Madison in The Federalist No. 51, "the rights of the minority will be insecure." "[T] moments in public affairs," he opined in The Federalist No. 63, "when the people stimulated by some irregular passion, or some illicit advantage, or misled by the artful misrepresentations of interested men, may call for measures which they themselves will afterwards be the most ready to lament." Government must provide "safeguard[s] against the tyranny of [such] passions." "77

Madison and Hamilton ${ }^{78}$ had plenty of company in their distrust of majorities. As Charles Beard has cynically noted, simple direct majority

72. Riker has a compelling point here. Populism, he argues, depends on the existence of popular will discovered by voting. But, if voting does not reveal a will, if the people speak in meaningless tongues, populism as a concept is rendered quite empty. W. Riker, supra note 61, at 239.

73. The Federalist No. 10, at 57 (J. Madison).

74. Id. at 60 (J. Madison).

75. Id. at 60-61 (J. Madison).

76. Id. No. 51 , at 351 (J. Madison).

77. Il. No. 63, at 425 (J. Madison); see also id. No. 49, at 343 (J. Madison) (government should regulate and control passions of public).

78. See, e.g., id. No. 71, at 482 (A. Hamilton) (when interests of people are at variance with their inclinations, elected representatives are duty bound to withstand people's temporary delusions). 
rule "was undoubtedly more odious to most of the delegates to the Convention than was slavery." Indeed, some historians contend that the central problem that prompted the convening of the delegates at Philadelphia was not the weaknesses of the Articles of Confederation but concern over an excess of populism in the state governments. ${ }^{80}$ What Madison called the "inconveniences of democracy" threatened creditor rights and individual property interests. ${ }^{81}$ And the delegates-representing the "haves"-had plenty to fear from the masses of "have nots."

It is idle (but fun nonetheless) to speculate how the delegates might have responded to a proposal that the Constitution contain provisions for initiatives or referenda. Such devices were virtually unknown to them. ${ }^{82}$ But everything about the tone of the Convention suggests that they would have looked upon such a scheme "with a feeling akin to horror."83 This impression is reinforced by the fate of a proposal to include in the First Amendment a right of the people to "instruct their representatives." Madison and his fellow Federalists labored mightily-and successfully-to block this attempt, fearing the consequences should the representatives feel bound to follow the instructions. ${ }^{84}$

All of this is pretty odd conduct for a lot supposedly committed to rul-

79. See Beard's introductory comments in Documents on THE STATE-wide INrTIative, REFERENDUM AND Recall 29 (C. Beard \& B. Schultz eds. 1912) [hereinafter Documents]. At the Convention, Edmund Randolph complained of "the . . . follies of democracy," Elbridge Gerry called democracy "the worst of all political evils," and Roger Sherman prayed that the people "have as little to do as may be about the government." See Lobel, supra note 19, at 827-28.

80. Sep, e.g., Wood, Democracy and the Constitution, in How Democratic is the ConstituTION 1-17 (R. Goldwin \& W. Schambra eds. 1980). But see H.P. Hood \& Sons, Inc. v. Du Mond, 336 U.S. 525, 533 (1949) (sole purpose for which Virginia initiated movement which ultimately produced Constitution was to deal with economic Balkanization); Eule, Laying the Dormant Cominerce Clause to Rest, 91 YALE L.J. 425, 430 (1982) (commercial warfare between states generally regarded to be the primary catalyst for Convention of 1787).

81. Spe 1 The Records of the Federal Convention of 1787, at 134-35 (M. Farrand ed. 1966). Bruce Ackerman argues, quite persuasively, that Madison's concern about democratic excesses was not limited to the fear of materialistic special interests. No less threatening were factions based upon narrow ideological ends-for example, the effort by sectarian groups to establish their own Church. See Ackerman, Storrs Leclures, supra note 2, at 1022 n.16; see also Diamond, Decent, Even Though Democratic, in How Democratic IS THE Constrtution, supra note 80, at 29 (Madison was troubled not only by "poor" majorities but also by majorities united by attachment to particular religion, philosuphical point of view, or spellbinding demagogue).

82. Participatory government of a very limited kind did exist in eighteenth-century America. Although some have traced decision-making by referendum back as far as seventeenth-century Massachusetts, sep T. CroniN, supra note 16, at 12, its first statewide use appears to have occurred when the citizens of Massachusetts ratified their state constitution less than a decade before the Philadelphia Convention. Spe REFERENDUMS, supra note 25, at 68-69; Eule, supra note 7, at 394-95.

83. DOCUMENTS, supra note 79 , at $28-29$ (no one has any warrant for assuming that Founders would have countenanced a system of initiatives or referenda applied either to state or national affairs),

84. See Amar, supra note 2, at 1058-60; 1 Annals of Cong. 733-45 (J. Gales ed. 1789); 5 The Founders' Constrtution 200-06 (P. Kurland \& R. Lerner eds. 1987); Sunstein, Beyond the Republican Rezival, 97 YALE L.J. 1539, 1559 n.113 (1989); Note, The Unconstitulionality of Voter Initintive Applications for Federal Constitutional Conventions, 85 CoLUM. L. REv. 1525, 1541 n.116 (1985), The phrasing was changed to: "Congress shall make no law . . . abridging . . . the right of the people . . . to petition the Government for a redress of grievances." U.S. CoNST., amend. I. 
ing with the consent of the people. At a minimum it counsels some hesitation when we talk in hushed tones of the Framers' dedication to "majority will." It may be too extreme to speak in terms of the "countermajoritarian premise" of the Constitution, ${ }^{85}$ but we must certainly recognize that majoritarianism "cannot be the whole story." clear intent of the delegates in Philadelphia to seek a direct link with the people by relying on popularly elected state conventions to ratify the Constitution, ${ }^{87}$ the people were to have no such direct role when it came to ordinary lawmaking-at least not at the Federal level. ${ }^{88}$

The Federalist "solutions" to the threat of majority faction are well known to readers of constitutional scholarship and there is little that I can add to that literature. ${ }^{89}$ There are, however, two reasons peculiar to my

85. See Farber, The Originalism Debate: A Guide jor the Perplexed, 49 OHro ST. L.J. 1085, 1099 (1989) (those who recognize that Constitution does not establish unmodified majoritarianism often talk about "counter-majoritarian premise" of Constitution); see also E. SCHATTSCHNEIDER, supra note 45, at 116 (somewhere along the line we started reading the Constitution as if it were a democratic document). Calling the Constitution "counter-majoritarian" seems a bit of an overstatement. However much it had to be qualified and guarded, Madison and the Federalists nevertheless seemed to believe that the principle of majority rule was at the core of Republican government. See, e.g., The Federalist No. 22, at 139 (A. Hamilton) ("fundamental maxim of republican government .. requires that the sense of the majority should prevail"). See aiso Madison's defense of majority rule as "the least imperfect" of all regimes in J. MADISON, Majority Governments, in THE MIND of The Founder: Sources of the Political Thought of James Madison $408-417$ (M. Meyers ed. 1981) (letter dated 1833 but probably never sent). Undoubtedly, followers of Charles Beard regard the Federalists' many expressions of devotion to majority rule as mere posturing and propaganda. See G. BEARD, AN ECONOMIC INTERPRETATION OF THE Constitution (1913) (Constitution was fundamentally anti-popular act masquerading in name of "the People"); see also Wood, supra note 80, at 15 (Federalists were compelled in ratifying debate and in their publications to minimize, even to disguise, elitist elements of the Constitution). But even if the Federalists cloaked their aristocratic document with a democratic mantle in order to induce ratification, the mantle has become a treasured part of our legacy. Even those enamoured with original intent as a guidepost for interpretation will have to demonstrate why the controlling intent should be that of the persons who wrote the Constitution rather than those they persuaded to ratify it. The key therefore may not be whether the Framers meant what they said but whether the state conventions thought that they did.

86. J. Ely, Democracy and Distrust: A Theory of Judicial Review 7 (1980); sec alsa Choper, On the Warren Court and Judicial Reriew, 17 CATH. U.L. Rev. 20, 38 (1967) (Constitution is antimajoritarian in important sense).

87. See generally' Eule, supra note 7, at 394-96. No such direct link, however, is mandated for constitutional amendments. Sef Hawke v. Smith, 253 U.S. 221 (1920) (where Congress has required that state legislature ratify amendment, state constitutional provision requiring that amendment be submitted to general referendum is without effect); AFL-CIO v. Eu, 36 Cal. 3d 687, 686 P.2d 609, 206 Cal. Rptr. 89 (1984) (voter initiative seeking Federal constitutional convention to consider proposed Balanced Budget Amendment-or requiring state legislature to make such request-does not conform to Article V which gives voters no direct role in the amending process); Harper v. Waltermire, 691 P.2d 826 (Mont. 1984) (to same effect as Eu). But see Amar, supra note 2 (Article V is not exclusive; current majority of People enjoy unenumerated right to amend Constitution in ways not explicitly set out in Article V); infra note 109. See generally Note, supra note 84.

88. See infra Part II.D for a discussion of limitations imposed on the structure of state government. For an excellent account of the Federalist's "dualistic conception of political life," distinguishing the people's role in constitutional politics from their more limited and indirect role in normal politics, see Ackerman, Storrs Lectures, supra note 2, and Ackerman, Constitutional Politics, supra note 2.

89. See, e.g., D. Epstein, The Polmtical Theory of the Federalist (1984); How DemoCRATIC Is the Constitution, supra note 80; G. Wills, Explaining America: The Federalist (1981); G. Wood, The Creation of the American Republic, 1776-1787 (1969); Ackerman, Storrs Lectures, supra note 2, at 1023-31; Sunstein, Interest Groups in American Public Lau, 38 Stan. L. Rev. 29, 38-48 (1985). 
endeavor here that warrant a short reiteration. First, and most obvious, the reader will note that most of the ways the Constitution devises to filter majority preferences are absent from direct democracy-at least from the substitutive version..$^{90}$ To gauge how much of a risk these missing filters pose to individual rights we must first comprehend what the Framers were trying to accomplish and how well their venture has fared. Second, and not nearly as apparent, I shall suggest that the role of the judiciary in the enforcement of Federal constitutional rights can only be understood in the context of this grand scheme of "solutions." Where courts are but one of many checks on majority preferences, they serve predominantly as a safety net to catch those grains of tyrannical majoritarianism that slip through when the constitutional filtering system malfunctions. ${ }^{91}$ Most arguments for judicial restraint, I shall suggest, ought not to be perceived as pro-majoritarian. They are more on the order of "everything in its place." The claim is not that majorities do not need checking, but that courts are just one of several "solutions" to majority factions. The delicate balance put in place by the Framers is disturbed as much by judicial hyperactivity as by judicial dormancy. Where, however, the filtering system has been removed, courts must play a larger role-not because direct democracy is unconstitutional, nor because it frequently produces legislation that we may find substantively displeasing or short sighted, but because the judiciary stands alone in guarding against the evils incident to transient, impassioned majorities that the Constitution seeks to dissipate. Only when we understand the contextual setting in which we ordinarily visualize judicial review can we formulate a picture of it when it is removed from its traditional context.

My assertion that the Federalists" "solutions" to the threat of majority faction must inform the judicial role in reviewing direct democracy does not overlook the fact that it was principally the structure of the national government that commanded their attention. It may not be obvious that the Framers' structural checks on majorities have relevance to state lawmaking processes. In Part II.D.1, I seek to demonstrate the relevance by exploring the constitutional provision guaranteeing each state a "Republican Form of Government." No claim is made that this clause demands

90. Complementary direct democracy appears to provide an additional filtering device. Thus legislative enactments that have survived the various Federalist "solutions" must surmount one more hurdle-voter ratification. At first glance, therefore, complementary direct democracy looks like yet another check against majority tyranny. No law takes effect unless it passes through both the representative and plebiscitary process. As it turns out, however, this account is too simplified. See infra Part III.B.

91. If this standard strikes readers as driven by Carolene Products they have not misread me. In my earlier work I have embraced a process-based vision of judicial review. See Eule, supra note 80 , at 428; Eule, supra note 7, at 384-85. For a general description of judicial review as a policing of the mechanisms of representative government, see J. ELY, supra note 86. It is not necessary, however, for the reader to embrace my vision of judicial review of legislative action in order to accept the thesis of this Article. 
strict adherence to the Federal form in the framing of state government. Nonetheless, the clause captures a distinctive vision-a vision that can be appreciated only by first understanding the Framers' sense of republicanism and its contrast with unfiltered democracy. The constitutional scheme embraced by the Framers runs majoritarian preferences through a complex filtering mechanism. Its two primary components may be called the Representation Filter and The Divided Power Filter. Its fall-back position, adopted largely as an accommodation to the Antifederalists, may be called the Entrenched-Rights Safety Net.

\section{The Representation Filter}

The true distinction between the "pure democracies of Greece" and the American government, explained Madison, "lies in the total exclusion of the people in their collective capacity from any share in the latter." was this distinction that the Federalists believed might permit our government to succeed where other democracies had failed. The problems posed by majority factions were most acute in a direct democracy. Placing the exclusive power of ordinary lawmaking in governors distinct from the governed checked "the inducements to sacrifice the weaker party, or an obnoxious individual." Public views can be "refine[d] and enlarge[d] . . by passing them through the medium of a chosen body of citizens, whose wisdom may best discern the true interest of their country, and whose patriotism and love of justice, will be least likely to sacrifice it to temporary or partial considerations." ${ }^{\text {93 }}$ This was not a wholly naive or elitist vision of representatives as morally and intellectually superior actors-although it is certainly not above criticism on either ground. ${ }^{94}$ The vision was a broader one. Its scope encompassed the virtues of deliberation and cooperation.

A major impetus for the representation filter-and one that has received added attention as a consequence of the work of Cass Sun$\operatorname{stein}^{95}$-is the opportunity it affords for deliberation and debate. Popular

92. The Federalist No. 63, at 428 (J. Madison) (emphasis in original).

93. Id. No. 10, at 61-62 (J. Madison). As Gary Wills so nicely puts it, the image is of "refining" in which a substance is passed through several processes to reach a pure state. Civic virtue is present in the people but it is in an impure state, mingled with private interest and local bias. Through refining, the interest is purged. G. Wills, supra note 89 , at 226.

94. Madison's suggestion that the large size of the voting base would make it difficult for "unworthy candidates to practice with success the vicious arts by which elections are too often carried," THE FEDERALIST No. 10, at 63 (J. Madison), seems overly optimistic-although he can hardly be faulted for failing to anticipate the impact of the mass media or runaway campaign spending. See also THE Federalist No. 3, at 15 (J. Jay) (once efficient national government is established, best men in country will consent to serve); J. Madison, Vices of the Political System of the United States, in 9 THE Papers of James Madison 357 (R. Rutland \& W. Rachal eds. 1975) (calling for process of elections as will extract from society purest and noblest characters it contains). But see H. PITkIN, THE CONCEPT OF REPRESENTATION 195 (1967) (Madison less concerned with moral or political superiority of representatives than with their capacity to withstand factional interests).

95. See Sunstein, supra note 89 (arguing for judicial review that encourages legislative 
masses too quickly form preferences, fail adequately to consider the interests of others, and are overly susceptible to contagious passions and the deceit of eloquent and ambitious leaders. ${ }^{96}$ In contrast, the deliberative process offers time for reflection, exposure to competing needs, and occasions for transforming preferences. Public debate among those of equal status and eloquence thus ultimately leads to realization of the common good. Whether this conceptualization of the legislative process is too cartoon-like to retain contemporary force is a question I leave for a later point in this Article. ${ }^{97}$ It is hard, however, not to feel persuaded by Akhil Amar's suggestion that while "we cannot force white voters to listen to blacks in their neighborhoods, . . . black legislators can interact with and influence their white colleagues." 98

That black legislators have influence with their white colleagues is attributable more than anything else to the ongoing nature of representative decision-making. Isolated decisions-like plebiscites-create few opportunities for trade-offs and little need for the establishment of continuing relationships. One just wins or loses. ${ }^{99}$ Representative government engenders cooperation because winners and losers return to meet again. Only, the next day brings different issues and shifting alliances. No one is always in the majority; therefore, no one can afford to turn a deaf ear to the needs of competing interests. I do not necessarily mean to suggest that the Federalists understood representative deliberation exclusively as a process of bargaining and trade-offs. Their version may have been closer to a form of collective reasoning. ${ }^{100}$ Under this utopian account legislators listen to one another because they are virtuous and because they share a common goal of discovering the public good. It is, however, no small part of the Federalists' genius that their design achieves many of its aims even when the actors fail to play their roles as hoped. Indeed, the Federalists planned for that very eventuality.

\section{The Divided Power Filter}

Because men were not angels, a government of representatives was needed to govern them. But because the governors themselves were men

\footnotetext{
"deliberation").

96. SeP J. MAdison, supra note 85, at 410 (unmailed letter of James Madison listing evils incident to popular assemblages).

97. Sep infra Part III.A.

98. Note, Choosing Representatizes by Lottery Voting, 93 Yale L.J. 1283, 1304 (1984).

99. See Michelman, Political Markets and Community Self-Determination: Competing Judicial Models of Lotal Gouermment Legitimac; 53 IND. L.J. 145, 182 (1977-78).

100. Which way one comes out on this depends in part on whether one views the Federalist vision as republican-where representatives would transcend special interests-or pluralist. Compare Sunstein, supra note 89 , at 46 ("The notion that politics might be conducted solely as a process of balancing and trade-offs. . . was far from the federalist understanding.") with H. Prrkin, supra note 94, at 195 (legislature provides forum in which social conflict "can be controlled by balancing and stalemating").
} 
rather than angels, controls on government were also necessary. ${ }^{101}$ The Federalists anticipated two ways in which the system of representation might fail. If representatives became too isolated, and the threat of regular elections was inadequate to tether them to the public good, they might "forget their obligations to their constituents." 102 Thus guards were needed against oppressive government leaders. At the same time, the Federalists feared that government leaders might prove too responsive to popular will and the representation filter would be an inadequate trap against majority tyranny. ${ }^{103}$ One solution, however, served to diminish both threats. Instead of a single representation filter, the Constitution would install several. Governmental authority would be divided so that no single entity would retain sufficient power to rule alone. The Federalists divided power both between distinct state and Federal governments (federalism) and-at least at the Federal level-among separate and distinct departments (separation of powers). These divisions of power were designed to check both the people's agents and the people themselves. The concept of "rule" would be so diffused as to make its oppressive use by government leaders untenable. In like manner, "an unjust combination of a majority of the whole" would be rendered improbable. The multiplicity of interests and sects would limit the people's power to act as a collective body and thereby ensure the security of minority civil and religious rights. ${ }^{104}$ The idea of divided power as a distinctive filtering mechanism is somewhat misleading. The vision is not really of a vertical chain of successive filters, each of which receives an ever smaller amount of tyrannical decisions. More accurately, the image is of a horizontal line of separate representation filters, each of which receives input from a different source but the cumulative outputs of which are needed to generate sufficient power to make the machine run. Majority tyranny will occasionally slip through a defective filter. But the taint that it produces in the end product will be merely fragmentary. Only a multiple breakdown will threaten the citizenry. Even this possibility, however, seemed too great a risk to some.

101. See The Federalist No. 51, at 349 (J. Madison).

102. See id. No. 62, at 418 (J. Madison).

103. See id. No. 51, at 351 (J. Madison):

It is of great importance in a republic, not only to guard the society against the oppression of its rulers; but to guard one part of the society against the injustice of the other part . . . . If a majority be united by a common interest, the rights of the minority will be insecure.

104. See The Federalist No. 51, at 351-52 (J. Madison); see also United States v. Brown, 381 U.S. 437, 443 (1965) ("[I]f governmental power is fractionalized, . . no man or group of men will be able to impose its unchecked will."); J. MADIson, supra note 85, at 412 (unmailed letter of James Madison) (those who framed and ratified Constitution believed that by dividing powers of government, "unjust majorities would be formed with still more difficulty"); THE FEDERALIST No. 47, at 324 (J. Madison) (accumulation of all power in same hands, whether of one, few, or many "may justly be pronounced the very definition of tyranny"). 


\section{The Entrenched-Rights Safety Net}

For the most part, the Framers believed that individual protection from majoritarian excesses could be secured more effectively by fragmenting power than by express limitation. ${ }^{108}$ They nonetheless harbored concerns over the adequacy of the divide and weaken strategy. What if the northern majority wanted to prohibit the slave trade? What if a large group of states ganged up to tax the exports of a too successful neighbor or deprive its ports of a natural advantage? What if the elaborate filtering system did not prove sufficient to protect the creditor minorities from the majority's will that debts be excused ${ }^{\text {106 }}$ It was clear that a few matters would have to be entrenched-placed beyond the reach of majority preferences, filtered or not. ${ }^{107}$ This did not mean that the rights selected for this protection were to be completely immune from encroachment by the political process. But a majority vote of ordinary legislatures would not suffice. Instead, the Framers erected an elaborate structure for alteration of the identified values ${ }^{108}$-one adorned with several filtering mechanisms. The amendment process was to be conducted by representatives. The people would enjoy no direct role under Article $V .{ }^{109}$ The exercise of the power was to be divided. The concurrence of each House of Congress plus the

105. See The Federalist No. 84 (A. Hamilton); 2 The Records of the Federal ConvenTION OF 1787, at 617-18 (M. Farrand ed. 1966); L. TRIBE, supra note 28, at 2.

106. Admittedly, the Framers' fear on this point was principally with majority tyranny on the state level. Accordingly the contracts clause casts its protective net over the state political process only. No doubt the Framers believed that the extended nature of the republic, the limited scope of power delegated to the Federal government, and the background of those who were likely to serve in the Congress (especially the Senate) would lessen the possibility of this kind of majority oppression at the national level. See 1 The Records of the Federal Convention of 1787, at 431 (M. Farrand ed. 1966) (Remarks of James Madison) (Senate will protect minority of opulent against majority). That they were not, however, entirely satisfied with reliance on these abstract safeguards is demonstrated by the inclusion of the ex post facto clause, applicable to the Federal government as well as to the states. See Crosskey, The Ex-Post-Facto and the Contracts Clauses in the Federal Convention: A Note on the Editorial Ingenuity of James Madison, 35 U. CHI. L. Rev. 248 (1968). But see Calder v. Bull, 3 U.S. (3 Dall.) 386 (1798) (ex post facto clause not applicable to non-criminal legislation). Support for the proposition that Calder provides a historically inaccurate rendition of the clause is collected at Eule, supra note 7 , at 427 n.219.

107. Most of the limitations on the federal government appear in Article $I, \S 9$ (e.g., imposition of 21 year bar on outlawing of slave trade; preclusion of tax on any article exported from state; ban on titles of nobility). See also U.S. CoNST. art. III, \& 3 (limiting crime of treason to levying war against United States and forbidding "Corruption of Blood" as punishment for such crime). Express limitations on the exercise of state legislative power appear in Article I, $\$ 10$ and in Article IV.

Some of these entrenched limitations seem designed more to provide a fair legislative process than to ensure particular substantive results. Thus the prohibition against ex post facto laws and bills of attainder-applicable at both the Federal and state level-prevent focused legislation and thus appear to anticipate the concerns of the equal protection clause. $C f$. J. ELY, supra note 86, at 90 (ex post facto and bill of attainder clauses "prove on analysis to be separation of powers provisions").

108. It is undoubtedly true, however, that the Framers were far more interested in entrenching the institutional structure that the Philadelphia Convention had labored to produce than in immunizing the few substantive values identified in the body of the Constitution from majority intrusion.

109. Sep supra note 87 . Article V does afford Congress the option to substitute popular ratifying conventions for the state legislatures. Congress need not, however, use the convention route, see United States v. Sprague, 282 U.S. 716 (1931), and in fact it has used this method of ratification only once. Sie Eule, supra note 7, at 415 n.169. 
state legislatures would be prerequisite to change. ${ }^{110}$ Finally, supermajorities were required both at the Federal level - where a two-thirds vote was necessary to propose an amendment-and at the state level-where ratification required the approval of three-fourths of the state legislatures.

With majority will so cabined it is hardly surprising that Antifederalists like Patrick Henry viewed Article $\mathrm{V}$ as the very antithesis of democracy. ${ }^{111}$ Yet, at the same time that they were condemning the immutable nature of the Gonstitution, the Antifederalists sought to augment its entrenched protections by affixing a bill of rights to the Constitution. Although some leading Antifederalists, like George Mason and Elbridge Gerry, feared majority tyranny as much as Madison, ${ }^{112}$ as a group they were a good deal more trusting of popular decision-making than were the Federalists. Their advocacy of a bill of rights was prompted less by a lack of faith in the people themselves than by a distrust of the organizations and institutions that presumed to speak for the people. ${ }^{113} \mathrm{It}$ is not without some irony therefore that their legacy is perhaps the single most striking counter-majoritarian check in the entire constitutional scheme.

While occasionally the Bill of Rights affords the people security against nonresponsive or despotic rulers, few would doubt that its more significant role has been to protect individuals from the tyranny of the group. We have little to fear from legislation lacking popular support. Usually the ordinary political process can be counted upon to "correct" it. Instead it is the law with widespread approval that poses the greatest danger to individual rights. As James Madison noted, "the invasion of private rights is chiefly to be apprehended, not from acts of Government contrary to the sense of its constituents, but from acts in which the Government is the mere instrument of the major number of the Constituents."114 Although initially resistant to the inclusion of a bill of rights, Madison was later to press for congressional adoption of the first ten amendments, recognizing in it yet another device for filtering majoritarian preferences-for it afforded a role for the judiciary in curbing the more immediately responsive and accountable branches. ${ }^{115}$

110. Although Article V allows the state legislatures partially to bypass Congress at the proposal stage by convening a Constitutional Convention, the Constitution does not permit Congress to be cut out of the amendment loop altogether. It is not clear, however, exactly what the congressional role would be in assessing the sufficiency of the state's application for such a Convention or in defining its scope or procedures. To date the Convention method for proposing amendments has never been utilized.

111. See 5 The Complete Anti-Federalist 216-17 (H. Storing ed. 1981) ("majority" of community must have right to alter their government).

112. See G. WooD, supra note 89 , at 484 .

113. Id. at 520 .

114. J. Madison, To Thomas Jefferson, in 11 The Papers of James Madison 295, 298 (R. Rutkind \& C. Hobson eds. 1977) (letter dated Oct. 17, 1788).

115. Sep G. Wood, supra note 89, at 542-43. See also Madison's speech in the House of Representatives, June 8, 1789. J. Madison, Consent and Consensus, in THE Mind of The Founder: Sources of the Political Thought of James Madison, supra note 85, at 169, 171-72 (Bill of 


\section{G. The Constitutional Context of Judicial Review}

\section{Is the "Difficulty" With Judicial Review Really a Counter- Majoritarian One?}

Edward Corwin once testified before Congress that the "people who say the frarners intended [judicial review] are talking nonsense ... and the people who say they did not intend it are talking nonsense."116 Admittedly, the constitutional text and historical record may be inconclusive. ${ }^{117}$ Yet no contemporary scholar relies on these ambiguities to assert the total absence of judicial power to pass on the constitutionality of legislative acts. Acquiescence has long since legitimated judicial review. Current debate instead revolves around the extent to which the power may properly be exercised. This does not mean, however, that the Framers' efforts are of no relevance. Ultimately the controversy over the scope of the judicial role boils down to reconciling judicial review-the invocation of power by an unelected and largely unaccountable governmental body-with a society that deems itself democratic. Democracy is a slippery term. And it seems odd indeed to attempt to effect a balance between the competing tensions without paying careful attention to the constitutional picture of democracy.

Alexander Bickel unwittingly has led us astray. The "root difficulty" of judicial review, he taught us, is its "counter-majoritarian" nature. ${ }^{118} \mathrm{His}$ error is less in his theory than in his terminology. American democracy - as portrayed in the Constitution at least-is not synonymous with majoritarianism. It was not intended as such, nor does it so operate. Bickel understood that. He described judicial review as thwarting "the will of representatives." What we mean by democracy, he said, "is much more sophisticated and complex than the making of decisions in town meeting by a show of hands."119 It is rather "the policy-making power of representative institutions" that "is the distinguishing characteristic of the system" and, he concluded, "[j]udicial review works counter to this characteristic."120 Yet Bickel too cavalierly glides over the distinctions between representative government and majoritarianism when it comes to labeling the "difficulty" with judicial review. It is a significant oversight. The very

Rights may be one means "to control the majority" and will enable judiciary to be "an impenetrable bulwark" against encroachment upon enumerated rights).

116. Reorganization of the Federal Judiciary: Hearings on S. 1392 Before the Senate Comm. on the Judiciary, Parl 2, 75th Cong., 1st Sess. 176 (1937). Corwin's comments were in response to a question regarding only judicial review of congressional acts.

117. But spe A. BICKEL, supra note 2, at 15 (historical hypotheses are not "provable with mathematical precision. But it is as clear as such matters can be that the Framers . . . expected that the federal courts would assume a power-of whatever exact dimensions-to pass on the constitutionality of actions of the Congress and the President, as well as of the several states.").

118. Id. at 16 .

119. Id. at 17.

120. Ill. at 19. 
premise of the structure erected by the Framers rests on the fundamental differences between the two.

The "difficulty" with judicial review entails its reconciliation with the constitutional version of democracy, not with some abstract form that exalts unfiltered majoritarianism. It would be more accurately conceptualized as a "counter-representative" or "counter-republican" difficulty. The Framers rejected simple majority rule because of their fear of factions. In its place they installed a representative structure which simultaneously enjoyed a relative detachment from and an ultimate accountability to the populace. And to ensure that neither detachment nor accountability got the upper hand, they separated and divided the repositories of power. The role of the judge can only be assessed within the confines of this framework. Jonathan Macey seems closer to the mark when he identifies the tension as one between the judicial checking role-implicit in a system of checks and balances-and the lawmaking function of the legislature explicitly set forth in Article I. ${ }^{121}$

It would be foolhardy, of course, to contend sweepingly that reverence for majority rule has nothing to do with the case for judicial restraint. It may be true that legislative enactments ordinarily reflect majoritarian preferences. While the Framers designed the filter system to (occasionally) block the passage of laws enjoying majority support, they did not intend to enable enactment in the face of majority opposition. ${ }^{122}$ Moreover, it is certainly accurate to say, as John Ely does, that even if legislatures are not wholly democratic, they are certainly more democratic-however defined-than courts. ${ }^{123}$ But conceding that legislative enactments often represent majority will does not make the central problem with judicial review a counter-majoritarian one. Legislative products represent far more than a simple aggregation of majority will. The enactments that reach the judiciary via the legislative route are those that have successfully passed through an extensive filtering system. This is majoritarianism plus. It is the plus that reflects the Framers' unique version of democracy, and it is the plus that warrants judicial caution in substituting its own judgment. Refined, or filtered majoritarianism, captures the virtues of popular sovereignty without being tainted by its vices. Judicial review must be integrated into this design.

I am not bent on persuading the reader of any particular vision con-

121. Macey, Promoting Public-Regarding Legislation Through Statutory Interpretation: An Interest Group Model, 86 Colum. L. REv. 223, 225-26 (1986). See infra Part II.D for a necessarily altered expression of the tension when state laws rather than Federal laws are being reviewed.

122. Sep J. Choper, Judicial Review and the National Political Process 26 (1980) (most anti-majoritarian elements of legislative process are negative ones that prevent the translation of popular wishes into governing rules rather than produce laws that are contrary to majority sentiments). But see Amar, supra note 2, at 1084 (minority's power to veto can be leveraged into power to force adoption of unrelated bill-clever politicians can thus 'beat their 'shields' into 'swords,' transforming "checks' into 'spurs' ").

123. J. ELy, supra note 86 , at 67 . 
cerning the proper scope of judicial review of legislative action-although my biases undeniably shape the contours of my thesis. This venture is more a comparative one. Wherever one's starting point, the case for-or against-judicial deference looks different when applied to electoral decision-making. Once it is recognized that the restraints placed on judicial review by the constitutional scheme are not grounded in a deification of unfiltered majority preferences, the nature of these differences becomes clearer.

\section{Contextualizing the "Difficulty" With Judicial Review}

The judicial role must be contextualized. By this I mean that any evaluation of the appropriate scope of judicial review under the United States Constitution is highly dependent on the nature of the particular body and process that produces the governmental act under attack. On occasion we are sensitive to this need to contextualize. For example, in a system resting upon the principle of national supremacy, Federal judicial review of state legislation is generally seen as raising different questions than the oversight of congressional action. Judicial review of the plebiscite has not profited from such a sensitivity. Yet, as I shall urge below, a constitutional framework with a normative preference for representative government demands that we conceptualize a different judicial role when the law under review emanates from the electorate rather than a legislative body. ${ }^{\mathbf{1 2 4}}$

Most of the arguments generally offered on behalf of judicial restraint-separation of powers, the non-exclusivity of judicial interpretations of the Constitution, and the superior capacity of legislatures for fact-

124. Judicial review is not limited, of course, to scrutinizing legislation, whether emanating from legislatures or the electorate. Federal courts often rule on the constitutionality of action taken by members of the executive branch, administrative agencies, or state courts. Surprisingly little of the literature on judicial review addresses the reconciliation of these other forms of judicial oversight with democratic principles. It is almost as if the issues are assumed to be identical to those encountered when Federal courts review a legislative act. See, e.g., A. Bickel, supra note 2, at 20 ("so long as there has been a meaningful delegation by the legislature to administrators, . . . the essential majority power is there" in way that it is not with judiciary); Maltz, Individual Rights and State Autonomy; 12 Harv. J.L. \& Pub. Pol'y 163, 171 (1989) (no court or commentator has ever suggested that judicially created rules should be scrutinized more closely than legislative decision-making). I believe this assumption to be dead wrong, because a theory of judicial review must be contextualized. See Eule, supra note 7, at 449-52 (different standard ought to govern our assessment of retroactive legislation when the displaced status quo is judge-made rather than statutory since statutes are politically superior to common law decisions); see also Brief for Petitioner at 56 n.31, Ferri v. Ackerman, 444 U.S. 355 (1979) (No.78-5981) (traditional reluctance to interfere with choices made by people's representatives dissipates when reviewing common-law doctrines). My immediate goal is to apply this premise to judicial review of direct democracy-comparing it to judicial review of legislative action-and little attention will be devoted here to what I see as its application in other settings. The broader message particularly resonant to a process-oriented scholar is that theories of judicial review can no more ignore the "who" than the "how" and the "what" of the governmental action subjected to a court's scrutiny. Sep C. Black, Structure and Relationship in Constitutional Law 69-70 (1969) (assessment of political meaning of judicial review very much depends on answers to questions like: "Whose action is the Court annulling? Whom is the Court second-guessing? Who, before the Court acts, has made the critical determination which the Court is asked to reverse?"). 
finding-appear to have little application to the scrutiny of citizen lawmaking. This is hardly surprising. Advocates of judicial deference generally assume, as did Bickel, the existence of a representative government.

The judiciary is a part of the Constitution's mutual checking design, but it is only one actor in a play with many characters. Judges, it is argued, must be sensitive to the usurpation of the role assigned the others. In part, this is because the others perform certain tasks better. In part, it is because a concentration of power in any single body-be it the executive, the legislature, or the judiciary-offends the constitutional vision. Separation of powers is thus a large part of the case for judicial restraint. Nowhere is the centrality of separation of powers concerns to the definition of the judicial role more evident than in the disparate treatment that advocates of judicial restraint sometimes accord Marbury v. Madison ${ }^{125}$ and Martin $v$. Hunter's Lessee. ${ }^{126}$ Bickel himself noted that "[m]any judges and commentators who have questioned the power of judicial review of federal legislation have freely conceded the same power when exercised with respect to state actions." ${ }^{127}$ When a Federal court declares an act of the Congress unconstitutional, it encroaches on the authority of a coordinate and equal branch of government to make law, a power that Article I explicitly confers upon the legislative branch. This disturbs the constitutional division of powers, and courts are urged to do so sparingly. When it is state legislation that is being reviewed for its compatability with the Federal Constitution, the picture is a different one. Here, the supremacy clause of Article VI demands a larger role from the judiciary. However debatable the advocates of judicial restraint find Marbury's conclusion that Federal judges may pass on the efforts of coordinate branches, the judicial power articulated in Hunter's Lessee ${ }^{\mathbf{1 2 8}}$ to review state legislative efforts is generally perceived as beyond reproach. Even James Bradley Thayer, as persistent and as ardent an opponent of an active judiciary as one is likely to find, experiences a conversion when the restraints of separation of powers give way to the hierarchy of the supremacy clause: "The judiciary now speaks as representing a paramount constitution and government, whose duty it is, in all its departments, to allow to that con-

125. 5 U.S. (1 Cranch) 137 (1803).

126. 14 U.S. (1 Wheat.) 304 (1816).

127. See A. BICKEL, supra note 2, at 33. Bickel tries to distance himself somewhat from this position. Although acknowledging that it is vital that the Federal judiciary have power to declare and apply Federal law-including constitutional law-to the member states, he reminds us that "it remains true that [the Court] . . . is acting against the majority will within the given jurisdiction." Id. Thus, as we have already seen, the root difficulty of judicial review for Bickel is its countermajoritarian nature and not the separation of powers issue.

128. Although Martin v. Hunter's Lessee itself involved review of state court decisions, not state laws, the Court's reasoning was obviously meant to apply to the latter problem as well. See, e.g., Fletcher v. Peck, 10 U.S. ( 6 Cranch) 87 (1810) (striking down state legislation as violation of contracts clause). 
stitution nothing less than its just and true interpretation; and having fixed this, to guard it against any inroads from without."129

This does not mean that an alternative case for restraint is not available when state laws are under review. Legislatures on the state level, no less than Congress, can claim an edge in expertise and accountability that warrants judicial deference. And federalism may fill part of the gap left by the departure of the separation of powers constraint. ${ }^{130}$ But, because the Constitution itself confers supremacy on the Federal Government, the argument for judicial restraint is altered in this context and, in the view of many commentators, is left substantially weaker. ${ }^{131}$

There is an important lesson here. Federal courts are creatures of the Constitution. Their role must be defined both by the story line and their relation to the other characters in the script. ${ }^{132}$ The judicial role is thus a relative one. One cannot talk of judicial deference in a vacuum. One first has to know who or what demands the deference. The Constitution does not establish equality among all actors in the political picture. Residing in its explicit language and its tacit assumptions is a hierarchy. In seeking the proper role for courts under our constitutional system we ought to respect that hierarchy.

The constitutional hierarchy is constructed on the Framers' relative assessments of trust. Different decision-makers and different methods of arriving at decisions pose different threats of faction. The extended republic is less to be feared than are local governments; ${ }^{133}$ dissipated command is

129. Thayer, The Origin and Scope of the American Doctrine of Constitutional Law, 7 HARv. L. REv. 129, 154-55 (1893). See also Eakin v. Raub, 12 Serg. \& Rawle 330 (Pa. 1825), where Justice Gibson ends his celebrated attack on Marbury by conceding the legitimacy of judicial review of state action for conformity with "supreme" Federal obligations.

130. One recent commentator argues, in fact, that the pull of federalism is oftentimes so strong as to justify greater judicial deference in the review of state actions than in the review of Federal action. $\mathrm{Ser}$ Maltz, supra note 124. If one were to embrace such a view it might be as applicable to state plebiscites as to actions of the state legislature. But see infra Part II.D. Despite an admirable effort by Professor Maltz, I remain unconvinced. His historical argument underplays the extent of the Framers' fears of faction at the local level, see infra note 133 and accompanying text, and his policy arguments undervalue their validity.

131. E.g., C. BLACK, supra note 124, at 71-76; L. TRIBE, supra note 28 , at 13 n.7; Amar, supra note 2, at 1079 n.128; see also O.W. Holmes, Collected Legal Papers 295-96 (1920) (finding judicial review of state acts far more critical to survival of constitutional enterprise). Surprisingly, the subordinate position of the states under the supremacy clause-and the consequent ease with which Federal judicial oversight may be legitimated-seldom translates into an articulated willingness on the part of the Supreme Court to apply a different standard to review of state and Federal laws. But see Blodgett v. Holden, 275 U.S. 142, 148 (1927) (opinion of Holmes, J.) (judicial review of an Act of Congress is "the gravest and most delicate duty that this Court is called upon to perform"). Compare Fullilove v. Klutznick, 448 U.S. 448, 472 (1980) (upholding Federal minority set-aside program in part because of "appropriate deference to the Congress, a co-equal branch") with City of Richmond v. J.A. Croson Co., 109 S. Ct. 706, 719-20 (1989) (striking down municipal set-aside program under equal protection clause in part because states and their political subdivisions lack broad remedial powers granted to Congress by $\S 5$ of Fourteenth Amendment and thus deserve less deference in adoption of racially-conscious remedies).

132. See generally C. BLACK, supra note 124, at 67-98 (exploring implications of constitutional structure on practice of judicial review).

133. For Madison especially, small societies embracing fewer distinct parties and interests maxi- 
less to be feared than concentrated power, ${ }^{134}$ and indirect democracy is less to be feared than plebiscites. The Constitution's exaltation of representative over direct democracy may be less forthrightly expressed than its other preferences, but it is no less central. Just as Article VI reveals a distinctive vision of the relative status of Federal and state governments, it sheds light on the place of electoral lawmaking in a way that has previously gone unnoticed.

Article VI demands an oath of all public officers-whether Federal or state- to support the Constitution. Legislators are thus obligated to determine the constitutionality of proposed legislation. ${ }^{\mathbf{1 3 5}}$ Judicial interpretations of the Constitution may be supreme, ${ }^{136}$ but they are not exclusive. The architects of the doctrine of judicial restraint drew great significance from this sharing of interpretive power. To them the law that reached a court had already been reviewed for its constitutionality and deserved deference as a consequence. Thus, Thayer questioned not the supremacy of the constitutional command over the majority preference, but the judicial role as exclusive expositor of those commands. He saw courts and legislatures as co-equal branches and demanded that judges afford a presumption of correctness to legislative judgments regarding constitutional questions. ${ }^{137}$

This argument for judicial deference is not extraordinarily persuasive to

mized the opportunities for oppression of minorities. "Extend the sphere," he exhorted, "and you take in a greater variety of parties and interests; you make it less probable that a majority of the whole will have a common motive to invade the rights of other citizens; or if such a common motive exists, it will be more difficult for all who feel it to discover their own strength, and to act in unison with each other." The Federalist No. 10, at 64 (J. Madison). For a contemporary invocation of the Framers' hierarchy as justification for distinguishing between the review of Federal and state (or local) action based on race, see Croson, $109 \mathrm{~S}$. Ct. at 736-37 (Scalia, J. concurring) ("to the children of the Founding Fathers"-who prophesied the heightened danger of oppression from political factions in small rather than large political units-"it should come as no surprise" that racial discrimination against any group finds more ready expression at state and local than at Federal level).

134. See INS v. Chadha, 462 U.S. 919, 946-51 (1983) (President's veto and bicameral requirement of Article I both guard against effects of faction by dividing and dispersing power).

135. See L. TRIBE, supra note 28, at 10, 16 (oath requires legislator to heed Constitution over constituents); Brest, The Conscientious Legislator's Guide to Constitutional Interpretation, 27 SraN. L. REv. 585, 587 (1975) (most obvious way for legislator to support Constitution is to enact only constitutional legislation).

136. Sep Cooper v. Aaron, 358 U.S. 1, 18 (1958) (Federal judiciary supreme in exposition of constitutional law). But see Meese, The Lau of the Constitution, 61 TuL. L. REv. 979, 983 (1987) (Supreme Court decision does not establish "supreme law of the land" that is binding on all persons and parts of government). Jefferson, Jackson, Lincoln, and Roosevelt all made statements similar to Meese's. See Tushnet, The Supreme Court, The Supreme Law of the Land, and Attorney General Meese: A Comment, 61 Tul. L. REv. 1017, 1018 (1987).

137. Thayer, supra note 129 , at 135 (preliminary determination of constitutionality by legislature is "a fact of very great importance"). Similarly, Henry Steele Commager portrayed judicial review as a second-guessing of a constitutional determination. "In support of every act," he argued, "is not only a majority vote for its wisdom but a majority vote for its constitutionality." A court voiding an act "opposes its own opinion on constitutionality to the opinions of the other two branches of the government." Commager, Judicial Review and Democracy in Judicial Review and THE Supreme Court 65 (L. Levy ed. 1967). See also Justice Holmes' opinion for the Court in Missouri, K. \& T. Ry. v. May, 194 U.S. 267, 270 (1904) ("II]t must be remembered that legislatures are ultimate guardians of the liberties . . . of the people in quite as great a degree as the courts."). 
our realist way of thinking. Perhaps we believe that legislators will fail to take their constitutional obligation seriously because of the press of time. Perhaps we are troubled that many legislators are not lawyers and lack the knowledge or skill necessary to adjudicate constitutional issues. Or, perhaps we think it naive to assume that the Constitution will prevail when political interests are threatened. ${ }^{\mathbf{1 3 8}}$ At the very least it is clear that most legislatures lack strong traditions of constitutional decisionmaking. ${ }^{139}$

But it is not necessary to embrace fully the factual premise of this claim for deference. Perhaps it is unworthy. A number of conclusions can nonetheless be drawn from the debate itself. First is the obvious inapplicability of a claim such as this to the plebiscitary process. There is no reason to believe that plebiscite campaigns will address the measure's constitutionality. Even if voters were made aware of such issues, the knowledge or information necessary to such a decision would be missing. The legislative tool of inviting legal experts to testify is unavailable.

More important, the Constitution does not ask the voters to assess a measure's constitutionality. Article VI imposes the obligations of constitutional compliance on public officers, not the electorate. This reinforces the observation that the Framers never expected the electorate to be placed in a position where it would have to square public need with constitutional command. Several alternative explanations for Article VI's omission are feasible, but they all are wanting. One could argue that the Framers never mentioned the populace in Article VI because the idea of government by plebiscite never occurred to them. Even if this were true ${ }^{\mathbf{1 4 0}}$ it scarcely contradicts my thesis that the constitutional structure places direct democracy on a less revered plane than representative government. Alternatively, one might suggest that the failure to mention the people in Article VI simply recognizes their place as the sovereign. Constitutional limits do not bind the sovereign, the argument might go, because it is their source. ${ }^{141}$ This explanation is similarly unsatisfying. It is true, of course, that the Constitution's prohibitions are directed at government and not the populace, and Article VI's failure to mention the "people" merely reflects that vision. But that is precisely the point. When the electorate enacts laws it acts not

138. See M. Shapiro, Freedom of Speech: The Supreme Court and Judicial Review 30 (1966) (by final debate and voting on bill, so many commitments already made that injection of constitutional issue would not only be futile but in many instances appear to be "traitorous repudiation of pre-established agreements"). But see Brest, supra note 135, at 601 (suggesting that it may be premature to assume that legislators will neglect their obligation to interpret Constitution, at least until it is clear that they recognize this duty).

139. Ser Brest, Constitutional Citizenship, 34 Clev. St. L. REv. 175, 183 (1986).

140. But see supra text accompanying notes 82-84.

141. It is inaccurate, of course, to confuse the people of an individual state with the sovereign. Sovereign they may be for purposes of the state constitution, but sovereignty under the United States Constitution resides in a much larger entity of which the people of a single state are just a small part. Se' supra note 7. 
as a sovereign people but as a governmental body and the Framers of the Constitution never anticipated such a possibility. ${ }^{142}$

Just as arguments for judicial restraint based on separation of powers or the sharing of interpretive power fail to carry over to review of ballot measures, those premised on comparative competence make little sense when removed from the legislative context. The superior legislative ability to collect information and to sort it out is routinely invoked by courts deferring to legislative judgment. ${ }^{143}$ Whether or not legislators actually do outperform judges at fact-finding, both groups perform with a lot more proficiency than the electorate. ${ }^{144}$ If the accuracy of decision-making is to be our criterion, the electorate stands at an obvious disadvantage. It lacks the staff, resources, time, and understanding to compete favorably with either judges or legislators on this count.

Of course, arguments about comparative competence are about more than the accuracy of empirical assessments. Those who trumpet the legislature's edge over the judiciary rely in large part on the lawmakers' closeness to the populace. ${ }^{145}$ Accountability to the electorate is the touchstone of legitimacy. But we must not confuse electoral accountability with popular legislation. However we may appraise political theory arguments for direct democracy, the Constitution's choice is clear: It opts for the virtues of agency. ${ }^{146}$ Those who framed and ratified the Constitution thought that distance was necessary if wisdom and fairness were to prevail. They valued a removed deliberation over impassioned-and often imprudent-decision-making. The Framers did not deny the electorate a role. The people were to speak through periodic elections. "Frequent elections," warned Madison, "are . . . the only policy" for effectively securing the government's dependence on and sympathy with the people. ${ }^{147}$ But when it came to ordinary lawmaking, popular participation was denied at the Federal level and, as I shall argue in Part II.D.1, disfavored at the

142. The American government, said Madison, will be characterized by "the total exclusion of the people in their collective capacity" from any part in it. The FEDERALIST No. 63, at 428 (J. Madison) (emphasis in original). In this particular quote Madison was referring only to the Federal government. The Framers' assumption, reflected in Article VI, is not so limited. See infra Part II.D.1.

143. This is done even where it appears that the legislature is factually mistaken. See, e.g., Minnesota v. Clover Leaf Creamery Co., 449 U.S. 456, 463-64 (1981).

144. See Linde, Due Process of Lawmaking, 55 NeB. L. REv. 197, 228 (1976) (once initiative measure is drafted it is past systematic factfinding). While Hans Linde uses this observation to argue that there can be no expectation of rationality in legislative action, see id. at 227, Lawrence Sager invokes it as part of an argument that plebiscites in some circumstances violate the due process clause. See Sager, Insular Majorities Unabated: Warth v. Seldin and City of Eastlake v. Forest City Enterprises, Inc., 91 HaRv. L. Rev. 1373, 1415 n.171 (1978).

145. See Dennis v. United States, 341 U.S. 494, 525 (1951) (Frankfurter, J., concurring) (courts are "not designed to be a good reflex of a democratic society"); Southern Pac. Co. v. Arizona, 325 U.S. 761, 794 (1945) (Black, J., dissenting) ("Representatives elected by the people to make their laws, rather than judges appointed to interpret those laws, can best determine the policies which govern the people.").

146. The origins of the agency concept are explored in Eule, supra note 7, at 394-96.

147. The Federalist No. 52, at 355 (J. Madison). 
state and local level. A theory of judicial review must take account of this constitutional preference. Just as deference to accountability preserves our democratic spirit, a wariness of unfiltered electoral expressions protects our republican form.

\section{Are States Laboratories for Unfiltered Experimentation?}

\section{The Federal Curb on State Experiments With Unfiltered Majorities}

A state may experiment with unfiltered majoritarianism only because the Federal Constitution provides a secure safety net. Individual rights trampled by voter excesses may be restored by congressional or judicial action. The question is not whether the protections afforded by the Fourteenth Amendment are applicable to voter enactments. That matter has long since been settled. ${ }^{148}$ The issue instead is whether the preference for representative government which I identify in Part II.B and use in II.C as a context for conceptualizing the judicial role can be extended to the structure of state government. I conclude that it can and that it should. My argument is thus both historical and normative.

The Constitution is not silent on the structure of state government. Article IV explicitly imposes an obligation on the United States-a term that ordinarily includes the judiciary-to "guarantee to every State in this Union a Republican Form of Government."149 The message appears clear. The clause says "Republican," not "Democratic." If we harbor any doubt about the difference, Madison is there to help out. "Democracy," he informs us, consists "of a small number of citizens, who assemble and administer the government in person." "A Republic," in contrast, is "a Government in which the scheme of representation takes place."160 The distinction is precisely what Madison hoped would bring the success that eluded earlier free societies. It is unlikely that the word "Republican" was loosely used. It came with a history and symbolized a vision. Its inclusion in Article IV is best understood as transporting that vision to the states. ${ }^{161}$

148. See, e.g., Pierce v. Society of Sisters, 268 U.S. 510 (1925) (striking down Oregon voter initiative imposing criminal liability on parents who failed to send their children to public school).

149. U.S. CoNST. art. IV, § 4.

150. The Federalist No. 10, at 61-62; see also Rice v. Foster, 4 Del. (4 Harr.) 479, 487 (1847) (characteristic that distinguishes republican government-as term is used in Article IV-is that "none of the powers of sovereignty are exercised by the people; but all of them by separate, coordinate branches of government in whom those powers are vested"). Madison's view was not shared by all his contemporaries. John Adams, for example, thought Madison's distinction unjustifiable, declaring that "a democracy is as really a republic as an oak is a tree, or a temple a building." See Documents, supra note 79, at 27. On the other hand, Adams later complained that he "never understood" what the guarantee of republican government meant. See W. Wiecek, The GuaranteE Clause of the U.S. Constitution 13 (1972).

151. Accord J. ELY, supra note 86, at 5 (constitutional document, "prescribing a republican form of government for the states, expresses its clear commitment to a system of representative democracy at both the federal and state levels"). 
This interpretation is substantially bolstered by the consistent use of the term "Legislature" whenever the Constitution confers power on state government. ${ }^{152}$

Now if this seems too easy, fear not. No matter how clear language appears we can always count on someone to muck it up. First there is the assertion that, notwithstanding the apparent implications of the Framers' choice of words, the debates reveal that the clause was actually placed in the Constitution to ensure that a state did not establish a monarchy or an aristocracy. ${ }^{153}$ It is undoubtedly true that for a few of the Framers that is all it meant. ${ }^{154}$ But scholars who have studied the historical record convincingly demonstrate a dual purpose behind the guarantee of a republican form. On one hand the delegates did worry about monarchy, concerned lest responses to excesses of populism at the state level tip too far in the opposite direction. ${ }^{155}$ On the other hand, it was in fact the threats to property, credit, and liberty posed by these popular excesses that drew many of the delegates to Philadelphia. ${ }^{158}$ Madison captured this duality when, near the close of his life, he described the ominous prospects that precipitated the Convention. The "unstable and unjust career of the States" had caused "a general decay of confidence \& credit." Those "most devoted to the principles and forms of Republics were alarmed for the cause of liberty." Those "least partial to popular Govt."-presumably the monarchists-"were yielding to anticipations that from an increase of the confusion a Govt. might result more congenial with their taste." 157 Just as the Framers' effort to structure the national regime was fueled by the twin fears of underresponsive and overresponsive government, so too was

152. See U.S. Const. art. I, § 3, cl. 1, (power to select Senators); id., art. I, § 4, cl. 1 (power to prescribe time, manner, and place for elections of members of Congress); id., art. I, $\S 8, \mathrm{cl}$. 17 (consent of state legislature needed for Federal purchase of land therein); id., art. II, $\S 1$, cl. 2 (power to establish manner for choosing presidential electors); id., art. IV, $\$ 3$, cl. 1 (consent of state legislature needed for combining or dividing of states); id., art. IV, $\S 4$ (power to apply to Federal Government for protection against domestic violence); id., art. V (power to apply for Constitutional Convention and ratify amendments). Note that when the states are prohibited from doing something the legislature is not specifically mentioned-although this is of uncertain significance since the drafters could have merely intended to bring the state executive branch within the prohibition. See id., art. I, \$ 10 .

153. See, e.g., In re Interrogatories, 189 Colo. 1, 11-12, 536 P.2d 308, 317 (1975) (main concern of Framers in adopting Article IV, $\S 4$ was to prevent state from changing government into monarchy).

154. John Randolph, for example, appeared to consider monarchy as the system with which republican government should be contrasted. See 1 THE Records OF THE Federal. Convention of 1787, at 202-06 (M. Farrand ed. 1966).

155. The disorder of absolute power in the hands of the people, they believed, inevitably led to the tyranny of the dictator. See G. Wood, supra note 89, at 19 (politics was viewed along "spectrum that ranged from absolute power in the hands of one person on one end, to absolute power.... in the hands of the people at the other end" and met in full circle where absolute popular power inevitably led to dictatorship).

156. See Wood, supra note 80, at 1-17; see also Bonfield, The Guarantee Clause of Article $\mathrm{V}$, Section 4: A Study in Constitutional Desuetude, 46 MiNN. L. Rev. 513, 517 (1962) (delegates feared that unfettered majority rule "could endanger property rights and destroy wise and enlightened leadership").

157. 3 The Records of the Federal Convention of 1787, supra note 154, at 548. 
their treatment of the states. Monarchy was unaccountable. It would not do. Neither, however, would the self-interested factionalism of the masses that prompted the appeal of monarchy. The republican form clause ${ }^{\mathbf{1 5 8}}$ was an effort to fix the balance. ${ }^{180}$

Reliance on the Framers' intent has its problems. Two in particular: "How can we know?" and "Why should we care?" Both have some relevance here.

The use of the word "Republican" in Article IV clearly did not have a single connotation for those who drafted the Constitution, let alone for the far greater number who ratified it. John Adams confessed that he never understood what the word meant and defended his confusion by asserting his belief that "no man ever did or ever will."160 Nonetheless, most of Adams' contemporaries seemed to share a sense of the clause's negative meaning-what it was trying to prevent-however incapable they may have been of answering the much more difficult question of what it was affirmatively seeking to achieve. But even if the clause's legislative history is inconclusive, the general themes of the entire constitutional document inform our interpretation. If ever a concept drew meaning from a look around the clauses of the Constitution, this is it. True, the structure the Constitution erects is meant for the federal government, and greater leeway is afforded the individual states. But the document does establish a republican form, and a republican form is what was guaranteed to the states. If we cannot ascertain exactly what the form ought to be, we can at least come up with an educated guess regarding its goals-accountability to the majority with filters to protect minorities.

The more difficult issue regarding Framers' intent is why we ought to care. Frequently our answer to this question depends on whether we agree with what the record shows-or at least on whether there is enough there to support our position. My own view is that intent is relevant but not dispositive. It is a starting point. Like every other clause in the Constitution the republican form clause deserves to grow and develop. ${ }^{161}$ As Senator Charles Sumner noted on the eve of launching his 1865 argument that the clause demanded suffrage for all races: "Words receive expansion

158. Although most scholars refer to Article IV, $\S 4$ as the guaranty clause, I prefer to emphasize what is guaranteed. Sep also J. ELy, supra note 86, at 118-19 \& n.* (calling it Republican Form of Government Clause).

159. SeP W. WIECEK, supra note 150 , at 11, 18, 20, 67, 75 (republican form clause was alternative to extremes of monarchy and-as exemplified by Shays' Rebellion-unchecked democracy); Bonfield, supra note 156, at 517 (delegates feared both popular tyranny and authoritarian power and sought "compromise between majority rule and minority rights"); Comment, The Guarantee of $R e-$ publican Goternment: Proposals for Judicial Review, 54 U. CHI. L. REv. 208, 231-32 (1987) (republican form clause charged Federal government with "preservation of the structure of state government necessary to maintain the dynamic between" accountability to people and "shortsighted unrestrained rule by whim of masses").

160. SPe W. WIECEK, supra note 150 , at 13.

161. Spe J. Ely, supra note 86, at 123. 
and elevation with time. Our fathers builded wiser than they knew. Did they simply mean a guarantee against a king? Something more, I believe,-all of which was not fully revealed to themselves, but which we must now declare in the light of our institutions." ${ }^{162}$

The minorities the Framers worried so much about-creditors, property owners, and the wealthy-are no longer those that call for special protection from society. They have learned to take care of themselves. When majorities tyrannize, the rich are seldom their victims. ${ }^{163}$ But Madison's admonition that "[i]t is of great importance in a republic . . . to guard one part of a society against the injustice of the other part"164 has lost nothing with time.

The judiciary is one of the prominent guardians of minority rights. But as we have seen, it ordinarily does not stand alone. A republic has other checks, other ways for ensuring that many voices have their say and no single faction dominates. If courts are needed to safeguard minority rights in a republic, the judicial task is that much more essential in an unfiltered democracy.

We now come to our second obstacle-a long list of cases that tell us that the judiciary has no role in the enforcement of the republican form clause. ${ }^{165}$ Yet the clause extends a guarantee with the "United States" as

162. See 4 Memoir and Letters of Gharles Suniner, 1860-1874, at 258-59 (E. Pierce ed. 1893) (letter to Francis Lieber, Oct. 12, 1865). A theory of the clause's development would be incomplete without an understanding of the post-Civil War metamorphosis in the constitutional attitude toward state autonomy. Although the Framers may have feared majority tyranny less at the local level than at the national level--inducing a willingness to immunize state government from constitutional restraint-the events leading to the Givil War demonstrated that their trust had been misplaced. The Reconstruction Amendments reflect a recognition that citizen control over state governments did not adequately safeguard individual liberty. They manifest an intent to confine majoritarian preferences at the state level. An enhanced suspicion of state departures from the republican model serves this end no less than the installation of an entrenched-rights safety net under the state lawmaking process. Of course, the Reconstruction Amendments do not say this, but the Constitution did not need alteration to reach this result. It already contained the republican form clause. The nation's first 80 years had simply revealed its importance.

163. An updated version of the golden rule acknowledges that he who owns the gold, rules. See Carter, Technology, Democracy, and the Manipulation of Consent, 93 YALE L.J. 581, 581 (1984) ("The critical problem for contemporary First Amendment theory is the unequal access that wealth can buy."); Nicholson, Campaign Financing and Equal Protection, 26 STAN. L. Rev. 815, 816 (1974) (large campaign contributions accord the wealthy "multiple representation"); Wright, Money and the Pollution of Politics: Is the First Amendment an Obstacle to Political Equality?, 82 Colum. L. REv. 609 (1982); see also First Nat'l Bank of Boston v. Bellotti, 435 U.S. 765, 809 (1978) (White, J., dissenting) (vast economic power of corporations threatens to dominate "the very heart of our democracy, the electoral process"); Buckley v. Valeo, 424 U.S. 1, 288 (1976) (Marshall, J., concurring in part and dissenting in part) ("One of the points on which all Members of the Court agree is that money is essential for effective communication in a political campaign.").

It may be that "sticking it to the rich" is likelier to occur in the plebiscitary process than in the legislative process. Indeed, that possibility in large part is what prompted the Progressives to champion direct democracy. Professor Lowenstein's study, however, convincingly demonstrates the efficacy of large sums of money in blocking unfavorable initiatives. Lowenstein, supra note 27.

164. The Federalist No. 51, at 351 (J. Madison).

165. E.g., Baker v. Carr, 369 U.S. 186, 218-26 (1962); Ohio ex rel. Davis v. Hildebrant, 241 U.S. 565 (1916); Marshall v. Dye, 231 U.S. 250 (1913); Kiernan v. Portland, 223 U.S. 151 (1912); Pacific States Tel. \& Tel. v. Oregon, 223 U.S. 118 (1912); cf. Reynolds v. Sims, 377 U.S. 533, 582 (1964) ("some questions raised under the Guaranty Clause are nonjusticiable, where 'political' in 
promised enforcer. If the Framers were unclear about the precise contours of a "Republic" they certainly harbored no doubt about what the term "United States" meant. ${ }^{188}$ The drafters could have designated "Congress" or "the President" as the enforcement agent. They did not, and the words chosen ought to be given their ordinary meaning. To the extent that judicial refusal to act is premised on the existence of a "textually demonstrable constitutional commitment of the issue to a coordinate political department," the claim rests on weak ground. ${ }^{167}$ Perhaps for this reason, more recent cases have relied instead on the Baker $v$. Carr argument that the clause provides no "judicially manageable standards." 188 This is an unfortunate doctrine. Judge Wisdom was never truer to his name than when he expressed the view that "[f]ederal courts should be loath to read out of the Constitution as judicially nonenforceable a provision that the Founding Fathers considered essential to formulation of a workable federalism."169

In Pacific States Telephone \& Telegraph Co. v. Oregon, ${ }^{170}$ the United States Supreme Court was asked to rule whether Oregon's use of the initiative to enact a gross-receipts tax was consistent with a republican form of government. The taxpayer argued that the representative nature of republican government prevented the people from taking legislative functions into their own hands. The Court never reached the merits of this claim. Speaking through Chief Justice White, it concluded that the question of whether a state government is "republican" was not one that courts are competent to answer.

In arriving at this result, White overstated the nature of the taxpayer's claim. As White saw it, the taxpayer was asking the Court to treat the entire state government as a nullity-an illegal government. In fact, only

nature and where there is a clear absence of judicially manageable standards"). Professor Tribe has suggested that these cases stand only for the proposition that the clause confers no judicially enforceable rights upon individuals, without precluding the possibility that it may confer such rights on the stales to whom the guarantee is explicitly extended. L. TRIBE, supra note 28, at 398. This seems an unduly narrow view of the cases-which draw no such distinction-and, more unfortunately, an unduly narrow view of the clause. See Comment, supra note 159, at 224-25 (Tribe's theory both unsound and inapplicable to this particular clause).

A very small number of courts have reached the merits of challenges raised under the republican form clause. See, e.g., VanSickle v. Shanahan, 212 Kan. 426, 439, 511 P.2d 223, 234 (1973) (case arising under guaranty clause justiciable if it involves "none of the traditional elements of a 'political" controversy").

166. See W. WIECEK, supra note 150 , at 76-77.

167. See Baker v. Carr, 369 U.S. 186, 242 n.2 (Douglas, J., concurring) (notion that "guaranty is enforceable only by Congress or the Chief Executive is not maintainable"); Note, Lousy Launaking: Questioning the Desirability and Constitutionality of Legislating by Initiative, 61 S. CAL. L. REv. 733, 766-68 (1988) (Court's designation of clause as nonjusticiable cannot be maintained on basis of commitment to another branch of government); Comment, supra note 159, at 217-19 (case for "textual commitment" is weak and has been abandoned by Court). But see Henkin, Is There a "Political Question" Doctrine?, 85 YALE L.J. 597, 609 (1976) ("The United States shall guarantee' plausibly refers to the political branches" exclusively).

168. 369 U.S. 186, 223 (1962).

169. Kohler v. Tugwell, 292 F. Supp. 978, 985 (E.D. La. 1968) (emphasis in original), affd, 393 U.S. 531 (1969).

170. 223 U.S. 118 (1912). 
the state constitutional amendment authorizing the initiative was challenged. Oregon still had an elected legislature. ${ }^{171}$ It still had a Governor. The initiative constituted but a small part of Oregon's governmental operation. The notion that a single unconstitutional feature would taint the entire structure is unsound. But it was this assumption that led White to find the precedent of Luther $v$. Borden "absolutely controlling."172 Here White made his second error. The holding in Luther-that Congress rather than the Court should be charged with determining which of two competing governments was the "true" government of Rhode Island-does not begin to answer even the distorted question that White had posed for the Court. ${ }^{173}$

White's invocation of the justiciability bar leaves us with no Supreme Court precedent on the constitutionality of direct democracy devices under the republican form clause. ${ }^{174}$ Several state court decisions prior to Pacific States had reached the merits of similar claims. Each rejected the claim. ${ }^{\mathbf{1 7 5}}$ I am inclined to think that they reached the correct result. No state-then or now-has abandoned representative government. The plebiscite thus serves an ancillary role only. ${ }^{178} \mathrm{~A}$ per se rule of invalidity in such a setting ${ }^{177}$ goes too far toward imposing a uniform model of republicanism on the states. This does not mean, however, that when the substance of a voter decision is judicially tested, the standard of review should be the same as that applied to legislation.

171. While it is true that the taxpayer's assignment of errors did assert that "the legislature . . . is destroyed by the initiative," $i d$. at 139 , there was no reason for the Court to take this statement to mean that the adoption of the initiative destroys "all government republican in form in Oregon," $i d$. at 141 (emphasis added). See Bonfield, supra note 156, at 554-55.

172. Pacific States, 223 U.S. at 143; see L. TRIBE, supra note 28, at 99 (describing White's assumption that invalidating initiative mechanism required nullifying Oregon government as "colorful" but "dubious"); Sager, supra note 144, at 1404-05 (describing White's analysis as shaky and as badly distorting issue before Court). Chief Justice White repeated his overstatement of the legal challenge to the plebiscite in Ohio ex rel. Davis v. Hildebrant, 241 U.S. 565, 569 (1916) (challenge to referendum "rest[s] upon the assumption that to include the referendum in the scope of the legislative power is to introduce a virus which in effect annihilates representative government.").

173. Luther involved a political tangle probably best left to Congress. See J. ELy, supra note 86, at $118 \mathrm{n}^{*}$. Since the President had already acted to recognize one of the competing Rhode Island governments, the possibility that co-ordinate branches might give conflicting answers was real and warranted judicial abdication. See W. WIECEK, supra note 150 , at 123-26.

174. Cf. City of Eastlake v. Forest City Enters., 426 U.S. 668, 679 (1976) ("referendum process does not, in itself, violate the Due Process Clause of the Fourteenth Amendment when applied to a rezoning ordinance"). For a different vision, see Sager, supra note 144, at 1418 (use of plebiscite may violate due process "where substantial constitutional values are placed in jeopardy . . . [and] where substantive review of the enactment by the judiciary is largely unavailable").

175. See In re Pfahler, 150 Cal. 71, 88 P. 270 (1906); Hopkins v. Duluth, 81 Minn. 189, 83 N.W. 536 (1900); Ex parte Wagner, 21 Okla. 33, 95 P. 435 (1908); Kiernan v. Portland, 57 Or. 454, 111 P. 379 (1910); Oregon v. Pacific States Tel. \& Tel., 53 Or. 162, 99 P. 427 (1909); Kadderly v. Oregon, 44 Or. 118, 74 P. 710 (1903); Bonner v. Belsterling, 104 Tex. 432, 138 S.W. 571 (1911).

176. One thoughtful commentator argues with some force that the plebiscite runs afoul of the Constitution when it exceeds its checking function. See Sirico, supra note 22, at 654; $c$. Comment, supra note 159, at 238-40 (plebiscitary forms constitutional for setting broad policy objectives but implementation decisions reserved for representative decision-making).

177. Occasional student notes propose such a rule. E.g., Note, supra note 167, at 772-76 (direct democracy unconstitutional means of adopting laws and of amending state constitutions). 
In the end, my claim is that direct democracy is constitutionally suspect, not impermissible. It triggers a harder judicial look. This argument is not hampered by the justiciability problems that surround the republican form clause, for I do not contend that this clause should be the lens under which direct democracy will be scrutinized. My argument instead is that when laws enacted by plebiscite are challenged under other provisions of the Federal constitution, the republican form clause informs the nature of the judicial role.

Hugo Black neglected to read the words of the republican form clause with the care and respect for which he was renowned. He may have been right when he remarked that letting the voters of the state directly legislate was "as near to democracy as you can get."178 What he failed to note was that the United States Constitution is not.

\section{Judicial Review Under State Constitutions}

Until this point $I$ have assumed that judicial review entails a challenge under a provision of the United States Constitution. Products of direct democracy-at least in their statutory form ${ }^{178}$ - can also be challenged under state constitutional provisions.

The preference for representative government revealed in the history and structure of the Federal constitution has no equal in the constitutions of the states where voters enjoy lawmaking power. More often than not these documents expressly proclaim something to the effect that "the people reserve to themselves the powers of initiative and referendum."180 Such state constitutions must fairly be read at least to give parity to direct democracy. Indeed, to the extent that voter initiatives and referenda are free to undo legislative decisions, while state legislatures often are constitutionally limited in the amendment or repeal of voter action, ${ }^{\mathbf{1 8 1}}$ a strong case may be made for the preferred position of citizen lawmaking. ${ }^{\mathbf{1 8 2}}$

178. 64 LANDMARK Briefs, supra note 11, at 668 (emphasis added).

179. Obviously it will be rare that a constitutional initiative or referendum will itself be challenged as unconstitutional under the state constitution. See supra note 28.

180. Cal. Const. art. IV, $\S 1$; see also, e.g., ARIZ. Const. art. IV, pt. 1, § 1. The California Constitution also proclaims that "[a]ll political power is inherent in the people" who enjoy the power to "alter or reform" government "when the public good may require." CAL. Const. art. II, $\$ 1$.

181. The degree of entrenchment varies. Some states entrench for a specified period of time only. See, e.g., ALASKa CONST, art. XI, § 6 (legislature may not repeal initiatives within 2 years of effective date); WYo. CoNst. art. III, §52(f) (same). Some require legislative supermajorities. See, e.g., ARK. CONST. amend. VII $\S 1$ (two-thirds vote of each House needed to repeal or amend initiatives); MICH. CONST., art. II, $\S 9$ (1963) (three-fourths of each House needed to repeal or amend initiative); N.D. ConST, art. III, $\$ 8$ (two-thirds vote of each House needed to repeal or amend initiative or referendum); WASH. CoNST. art. II, $\S 41$ (two-thirds of each House needed to amend or repeal initiative or referendum within 2 years of passage). Finally, one state prohibits any legislative modifications without voter approval regardless of how long has transpired since passage or how great a percentage of the legislators favor such a change. CAL. CoNST. art. II, $\$ 10$ (c) (legislature may not amend or repeal voter initiative without approval of electorate unless initiative provides otherwise).

182. In fact the conventional history holds that the very purpose behind the adoption of the initiative and referendum was to enable the voters to establish their supremacy over a corrupt and captured 
Naturally, state constitutions place some limits on citizen lawmaking. They mandate procedures and place certain rights beyond voter abrogation. But state judicial enforcement of these limitations has not always been vigorous. There are several legitimate justifications for judicial reluctance to invalidate voter action under the state constitution.

The Progressive movement that injected the initiative and the referendum into so many state constitutions feared special interest control of courts $^{183}$ as well as of legislatures. In several states, such as Colorado and Nevada, the state constitutions were amended to prohibit judicial invalidation of direct legislation. ${ }^{\mathbf{1 8 4}}$ Other more restrained efforts to control the judiciary included subjecting judges to constitutional recall provisions. ${ }^{185}$ Without a recall power over judges, reformers argued, the referendum and initiative would be "rendered valueless" by conservative judges seeking to reinstate the status quo. ${ }^{186}$ It is true that the recall device has almost never been used against judges, but its prevalence in state constitutions, and the reasons behind its adoption, confirm these documents' empowerment of unfiltered popular majorities. ${ }^{187}$

In fact, in the sixteen states whose constitutions permit amendment by a majority of the voters-neither requiring legislative review nor permitting legislative veto ${ }^{188}$ - sovereignty truly vests in an electoral majority. Judi-

representative process. See supra note 38 and accompanying text. For an interesting analysis of one facet of the conflict between representative government and popular sovereignty under the California Constitution, see Note, The Limits of Popular Sovereignty: Using the Initiative Power to Control Legislatite Procedure, 74 Calif. L. Rev. 491 (1986).

183. See, e.g., G. Mowry, supra note 38, at 140-42, 148 (as result of several rulings, California Supreme Court had become identified with corporate interests controlling state).

184. See Colo. Const. art. 6, $\$ 1$ (1913) (restriction applicable to lower state courts only); Nev. Const. art. XIX, $\$ 2$ (1904). The texts of both these provisions are set forth in J. BarnetT, ThE Operation of The Initiative, Referendum, and Recall in ORegon 174 n.1, 175 n.1 (1915) (citing Colo. Const. art. VI, §1 (1914), and Nev. ConST. art. XIX, § 2 (1904)). Although the Colorado provision is no longer in force, the Nevada provision can now be found at Nev. ConsT. art. XIX, $\S 1$, cl. 2. It is not likely, however, that any Nevada court would presently read this provision to bar its review of voter legislation under the state constitution. See Caine v. Robbins, 61 Nev. 416, 131 P.2d 516 (1942) (intent to permit use of initiative process to enact unconstitutional measure should not be presumed).

185. There seems to have been a split among the Progressives over whether state judges should be subject to recall. Critics warned that judges would be too hasty "to serve the mob." T. CRONIN, supra note 16 , at 131 . While such arguments no doubt contributed to the decision of six states specifically to exclude judges from recall, the majority of the fifteen state constitutions providing for recall include the judiciary. $I d$. at 126-27 (Table 6.1).

186. See Reasons Why Senate Constitutional Amendinent No. 23 Should Be Adopted, in Cal. Secretary of State, Proposed Amendments to the Constitution of the State of CalifORNIA WITh Legislative Reasons for and Against Adoption Thereof (1911).

187. That the recall is seldom used against judges, see T. CRONIN, supra note 16, at 143, does not mean that the state judiciary is not held electorally accountable. See infra Part III.C.

188. See Book of THE STATES, supra note 27, at 18 (Table 1.3). Nevada, however, requires that the electorate approve the amendment in two consecutive general elections. Id. at 18 . A seventeenth state, Massachusetts, permits a constitutional initiative to be placed on the ballot only after it is approved by one-fourth of the members of two successively elected legislatures. Id. at 18 n.b.

Several of these states limit the amendatory power of the electorate by distinguishing between "constitutional amendments" which may be done by voter initiative and "constitutional revisions" which require the calling of a constitutional convention. See Fischer, supra note 28, at 50-51; Comment, Judicial Revieu of Initiative Constitutional Amendments supra note 4, at 476-77. The line between 
cial review of legislative initiatives or referenda under state constitutions has a sense of futility in such settings. Constitutional initiatives are often responses to state judicial rulings. ${ }^{180}$ If a court strikes down voter legislation as incompatible with the state constitution the same electoral majority may join together to amend. Voters show no inclination to act with greater circumspection or self-restraint when confronted with constitutional amendments. The success rate for constitutional initiatives does not differ significantly from the passage rate for legislative initiatives. ${ }^{180}$ Using the state constitution as a judicial shield against the "sovereign's" legislative effort places an awful lot of weight on the form initially selected by the plebiscite's promoters. Considering the scant attention voters appear to pay to this form, ${ }^{191}$ and state constitutions' lack of additional filters for the amendatory process-save the additional signatures needed to secure placement on the ballot ${ }^{192}$ - a court's invalidation of voter legislation under the state constitution is a questionable preference for the voice of past electoral majorities over current ones.

The thesis I espouse here-that judicial scrutiny of plebiscites should be less restrained than judicial review of legislative efforts-therefore makes sense only when an attack is mounted under a provision of the Federal

the two is sometimes elusive. For an attempt at definition, see Amador Valley Joint Union High School District v. State Board of Equalization, 22 Cal. 3d 208, 223, 583 P.2d 1281, 1286 (1978) (enactment so extensive as to change the "substantial entirety" or which accomplishes "far reaching changes in the nature of (the] basic governmental plan" may constitute revision).

189. See Thompson, Judicial Retention Elections and Judicial Method: A Retrospective on the California Retention Election of 1986, 61 S. CAL. L. REv. 2007, 2017-18 (1988).

190. From 1898 to 1979 the passage rate was $38 \%$ for statutory initiatives and $34 \%$ for constitutional initiatives. See D. MaglebY, supra note 16, at 71 (Table 4.3); see also League of WoMEN VoTERS, supra note 18, at 26 (from 1912 to 1976 in California, pass rate was $28 \%$ for statutory initiatives and $27 \%$ for constitutional initiatives). There may, however, be a trend toward greater caution with constitutional initiatives. See D. MAGleby, supra note 16, at 72 (since 1950 passage rate for constitutional initiatives has been $30 \%$ as against $42 \%$ for statutory initiatives).

191. Voters do, however, seem to distinguish between referenda-whether statutory or constitutional-and initiatives. See D. Magleby, supra note 16, at 73 (Table 4.4) (passage rate for referenda from 1898 to 1978 was $60 \%$ as opposed to $34 \%$ for initiatives). It seems to matter less to the voters whether they are acting in a constitutive or legislative mode than whether legislative approval has preceded placement of a measure on the ballot. Perhaps the zoters themselves are skeptical about unfiltered exercises of popular will.

This supposition provides a degree of support for those who contend that electoral self-restraint renders initiatives less problematic than its critics suggest. See, e.g., Allen, supra note 18, at 1036-38. I address this possibility in Part III.A. On the other hand, there are alternative explanations for the higher passage rate of referenda. Initiatives tend to be more controversial and to depart further from the status quo. Cf. Romer \& Rosenthal, Modern Political Econony and the Study of Regulation, in Public Regulation: New Perspectives on Institutions and Policies 92 (E. Bailey ed. 1987) (high cost of changing status quo implies that pivotal voter's preferences must be far from status quo for initiative to gain support; this enables organizer to pass extreme proposal rather than proposal matching pivotal voter's ideal). In contrast, many referenda have been approved unanimously by the legislature. D. MagleBY, supra note 16, at 72 . Especially in the cases of mandatory referenda like debt authorization, the proposal may be routine and the opposition minimal. In such situations a higher pass rate is hardly surprising.

192. Ser supra note 28. Higher signature requirements do not appear to serve as much of a filter. In those states permitting both statutory and constitutional initiatives there have been nearly as many of the latter as the former. Indeed, in eight states there have been more constitutional initiatives than statutory ones. Sep D. MAGLEBX, supra note 16 , at 72. 
Constitution. Where the state constitution is the source of a judicial challenge, the absence of a representational bias and a different conceptualization of sovereignty ${ }^{193}$ render the argument inappropriate. State constitutions (in those states that permit direct democracy) embrace a vision of governance different from the one outlined in the earlier sections of this Article.

I take no firm position here on whether state constitutional review of citizen lawmaking warrants greater judicial deference than is ordinarily afforded to legislative action. It all depends on the state. It is risky to generalize without first undertaking an in-depth examination of the state's constitutive instrument. Nonetheless, let me offer three observations. First, the strongest case for enhanced deference will occur in the states whose constitutions afford the voters the same direct and unimpeded access to the amendatory process that they allow for legislation. ${ }^{194}$ In states which permit direct voter legislation but require legislative concurrence for constitutional amendment, ${ }^{195}$ the case will be a weaker one-for the vesting of sovereign power in an electoral majority has been hedged. Second, judicial review of local rather than statewide initiatives or referenda under the state constitution is another kettle of fish altogether. Finally, whatever may be the actual practice, state courts generally articulate the view that state constitutional challenges to voter legislation are subject to the same standard of review applied to laws passed in the ordinary manner. ${ }^{186}$

\section{Checking the Plebiscite}

\section{A. Judicial Review of Substitutive Plebiscites}

The thesis to this point may be roughly summarized as follows: The Constitution seeks to balance majority rule and minority rights. It enforces the government's obligation to the majority by requiring frequent elections. Legislative agents periodically return to the people for a renewal of their transitory mandates. They are held accountable for past actions and are exposed to shifting waves of public sentiment. Yet, government has an

193. See Amar, supra note 2, at 1063 n.73 ("People of a state may still be treated as "sovereign" over its state legislature and state constitution, but not over federal laws or the federal Constitution.").

194. After comparing state provisions for constitutional amendment with provisions for statutory initiatives, I place thirteen states in this category (Arizona, Arkansas, California, Colorado, Michigan, Missouri, Montana, Nebraska, North Dakota, Ohio, Oklahoma, Oregon and South Dakota). Because Nevada requires voters to approve amendments in two consecutive general elections, see BOOK OF THE STates, supra note 25 , at 18, I have not included it in this group. The Nevada filter's impact is demonstrated by the failure in 1980 of a property tax cut amendment after the same measure passed in 1978. Sep League of Women Voters, supra note 18 , at 87.

195. I place seven states in this category (Alaska, Idaho, Maine, Massachusetts, Utah, Washington and Wyoming).

196. See, P.g., Legislature v. Deukmejian, 34 Cal. 3d 658, 674, 669 P.2d 17, 26 (1983) ("statutory initiative is subject to the same state . . . constitutional limitations as are the Legislature and the statutes which it enacts"). But see id., 34 Cal. 3d at 683, 669 P.2d at 35 (Richardson, J., dissenting) (initiatives entitled to "very special and very favored treatment" (emphasis in original)). 
obligation to all of its citizens; the rights of individuals and minority groups must be protected against the actions of the majority. The Constitution seeks to enforce this obligation by (i) investing primary lawmaking authority in representatives rather than the people themselves; (ii) dividing the power of the lawmakers so that each unit may check the others; and (iii) placing certain principles beyond the reach of ordinary majorities. These protections are enforced by the mechanism of judicial review. ${ }^{197}$ Much sentiment exists for the proposition that the judiciary should exercise substantial self-restraint in performing its role. The argument for judicial deference, however, rests on the assumption that the structure itself-(i) and (ii)-guards against neglect of minority interests. In its substitutive form direct democracy bypasses internal safeguards designed to filter out or negate factionalism, prejudice, tyranny, and selfinterest. The judiciary must compensate for these process defects. It must serve as the first line of defense for minority interests; a back-up role is no longer adequate. The absence of structural safeguards demands that the judge take a harder look. A rough sketch for such a "hard look" approach is set forth in Part III.A.2.

I anticipate two major responses to this argument. First, one may attack the legislative process as something short of the Framers' vision. ${ }^{198}$ Second, one may defend substitutive plebiscites as more deliberative, more constrained, and less tyrannical than my model suggests. To the extent that my venture is a comparative one, both claims are relevant.

Initiatives, said then Governor Woodrow Wilson, must be contrasted "not with the representative government which we possess in theory... . but with the actual state of affairs." 199 It is undoubtedly true that many critics of the plebiscite overstate the deliberative capacity of the legislative process. The gap between theory and reality is probably most pronounced at the state and local levels where many legislators serve part-time and laws are often railroaded through en masse. ${ }^{200} \mathrm{~A}$ raft of public choice scholarship seeks to move us from a naive faith in the public-interest char-

197. It is plausible to conceive of courts as having the additional role of protecting majority rights by ensuring that legislation truly reflects popular values. This vision is more than a little problematic when applied to review of legislative efforts, for it assumes that courts can better gauge what the people want than can the legislature. See J. ELY, supra note 86, at 68-69. Applying it to electoral judgments would completely undermine a court's credibility. Substituting judicial will for voter preferences in the name of minority rights is one thing. Voiding electoral preferences in the name of majority will, while theoretically supportable, see supra Part II.A, borders on judicial suicide.

198. Cass Sunstein suggests that we are a far cry from Madison's vision of a deliberative democracy: Sunstein, supra note 89 , at 48-49. That the scenario Madison promised has not come to fruition, however, does not lead Sunstein to reject it as a normative vision-even if a somewhat romantic and utopian one. See id. at 81-85, 87.

199. Wilson, The Issues of Reform, in The Initiative, Referendum and Recall. 87 (W. Munro ed. 1912); see also Documents, supra note 79, at 33 (practice of representative government rather than theory should be basis of comparison with initiative); Briffault, supra note 19, at 1350 (direct legislation "in the field" bound to compare unfavorably with idealized construct of legislative process).

200. Sex Gillette, supra note 19, at 942 n.49; Briffault, supra note 19 , at 1362. 
acter of most legislation to what Richard Posner calls "a more realistic understanding of the importance of interest groups in the legislative process." 201

An in-depth evaluation of the competing pictures of legislative reality is beyond the scope of this Article. Choosing between the deliberative and interest group description of the legislative process is unnecessary because-as 1 suggest below-either affords minorities a greater role than they are likely to enjoy under the mere aggregative process of the substitutive plebiscite. Further, a good deal of the criticism leveled at the legislature has no bearing on my limited claim. The contention, for example, that legislators are inadequately accountable to or insufficiently responsive to majority preferences admittedly may argue for adopting or maintaining the initiative. ${ }^{202}$ Initiatives may be better gauges of popular will ${ }^{203}$ and elections may be an inadequate means of reminding representatives of their constituents' views on the issues of the day. But my thesis is several shades more modest than the claim that direct democracy is an unwise or unnecessary institution. Instead, my principal concern is with laws that are unduly insensitive to minority rights, not with those that fail to carry out popular will. The bridling of lawmakers who fail to heed the majority's voice must in large part occur through the political process ${ }^{204}$ and may warrant some structural revision. The monitoring of lawmakers who hear little else is a task that must ultimately rest with the courts.

In exploring the judicial role in protecting minority and individual rights, the relevant question is whether a system of deliberative, checkedand-balanced representative government lessens the probability that minority interests will be neglected, undervalued, or invaded. ${ }^{205}$ No one would be so naive as to deny that the deliberative ideal breaks down with disturbing frequency. The legislature often has trouble hearing voices from the margin. The Framers' vision, however, combined a deliberative idealism-which inspired representative government-with a pluralistic

201. R. Posner, The Federai Courts: Crisis and Reform 271 (1985); see also Macey, supra note 121, at 223 (special interest groups dominate political process); Wiley, A Capture Theory of Antitrust Federalism, 99 HARv. L. REv. 713, 723 (1986) (regulation has come to be conceived of as "a method of subsidizing private interests at the expense of public good.").

At times this literature swings too far in the opposite direction, manifesting a deep distrust of legislators that may be unwarranted. See Farber \& Frickey, supra note 65, at 874 (social science literature does not support deep distrust of legislatures implicit in public choice legal scholarship); $K$. Schlozman \& J. Tierney, Organized Interests and American Democracy 402 (1986) (public officials exercise independent leadership and influence and at times act in behalf of disadvantaged).

202. See Allen, supra note 18, at 978-1001; see also Wilson, supra note 199, at 88 (initiative provokes genuine representative action by legislative bodies).

203. But see supra Part II.A.

204. See supra note 197.

205. Professor Briffault poses the question somewhat differently: "The appropriate question is whether the initiative is more likely than the legislature to be a source of measures that discriminate against minorities or infringe upon the rights of the politically powerless." Briffault, supra note 19, at 1364. Interestingly enough, while Professor Briffault offers no "firm answer," he consoles himself by pointing to the judiciary as "mitigat[ing] the antiminority potential of direct legislation." Id. 
realism-which prompted cautionary checks. In other words, the process anticipates its own frailties by subdividing lawmaking authority. Of course, even this checking structure is far from foolproof. ${ }^{208}$ Recognizing the consequent need for enhanced judicial attention where the checking mechanisms themselves break down is what the Carolene Products footnote is all about. ${ }^{207}$

The problem with substitutive democracy is different. When naked preferences ${ }^{208}$ emerge from a plebiscite, it is not a consequence of system breakdown. Naked preferences are precisely what the system seeks to measure. Aggregation is all that it cares about. ${ }^{209}$ The threat to minority rights and interests here is structural. This is how the system is supposed to work. $^{210}$

\section{Equality and Individual Rights at Risk}

America's "outsiders" cannot have felt sanguine over the results of substitutive plebiscites in November 1988. Initiatives declared English the official language in Arizona, Colorado, and Florida. Voters in Arkansas, Colorado, and Michigan banned funding for poor women seeking abortions. California voters authorized involuntary AIDS testing for sex crime suspects and for assailants of police and emergency workers. And, in Oregon, an initiative repealed the Governor's executive order banning discrimination against lesbians and gay men in the executive branch. ${ }^{\mathbf{2 1 1}}$

A number of commentators argue that, notwithstanding the absence of checks and filters, direct democracy has a good track record and "can only rarely be faulted for impairing the rights of the powerless."212 There are

206. See Kahn, Reason and Will in the Origins of American Constitutionalism, 98 YALE L.J. 449,471 (1989) ("Political order . . . cannot always cure the disease of the soul. A properly structured system of representation and participation cannot guarantee political success."); see also Elliot, Ackerman \& Millian, Tourard a Theory of Statutory Exolution: The Federalization of Environmental Law, 1 J.L. ECON. \& ORg. 313, 328 (1985) (sometimes our polycentric lawmaking system has very different structural implications than intended; it "may sometimes encourage or reward rapid and extreme lawmaking").

207. United States v. Carolene Products, 304 U.S. 144, 152 n.4 (1938). See generally J. Ely, supra note 86.

208. The phrase is Cass Sunstein's. See Sunstein, Naked Preferences and the Constitution, 84 CoLum. L. REv. 1689, 1689 (1984) (defining naked preference as "the distribution of resources or opportunities to one group rather than another solely on the ground that those favored have exercised the raw political power to obtain what they want").

209. See Kateb, The Moral Distinctiveness of Representative Democracy, 91 ETHIcs 357, 371 (1981) ("T The politics of direct democracy is pure numbers.").

210. Cf. Briffault, supra note 19, at 1364 ("[T]he challenge to the initiative for lack of sensitivity to minority interests is misguided; the initiative ... was designed as a majoritarian tool, to be used when the legislature failed to act on a program the majority desires." (emphasis in original)).

211. The results of the 1988 statewide ballot measures are compiled in 9 INITIATIVE AND REFERendum Report No. 10 (Dec. 1988), and Initiative \& Referendum: The Power of the People (Winter 1989).

212. Sep T. Cronin, supra note 16, at 92; see also Allen, supra note 18, at 1023 ("II]t is difficult to find abusive legislation enacted by initiative."). Allen admits, however, that initiatives may be more problematic at the local level than at the statewide level. Id. at 1007 n.215, 1026 n.304; $c$. Amar, supra note 2, at 1097 (tyrannical majorities greater problem at state than at national level). 
some stains, they concede, but no more than can be found on the legislative ledger. ${ }^{213}$ This is an extremely difficult claim to evaluate. ${ }^{214}$ Reliable empirical studies do not exist. ${ }^{215}$ Those who commend direct democracy's track record rely on anecdotes and erratic case counting. They fail to distinguish substitutive from complementary exercises of democracy, focus almost exclusively on statewide rather than the more prevalent local plebiscites, ${ }^{\mathbf{2 1 6}}$ and take no account of the comparative frequency with which voters and legislators act.

But the deficiencies of bottom line comparisons are more serious. As Professor Ronald Allen, a strong defender of the initiative's track record, himself concedes, evaluating the states' experience with the initiative "rests, in part, upon whether the outcomes of ballot measures meet with our approval."217 Assessing the extent to which plebiscites disregard the rights of minorities necessarily depends on judgments about whom we recognize as "minorities," what we view as their "rights," and how we measure voter "disregard." In offering my judgment that substitutive democracy in fact threatens minority interests to a degree beyond what might be expected from the representative process, I acknowledge the inevitable subjectivity of such a claim.

213. See T. Gronin, supra note 16, at 92 ("[A]lthough both direct and representative lawmaking have occasionally diminished the liberties of the politically powerless, neither can be singled out as more prone to this tendency."); Allen, supra note 18, at 1010-11 (there is "no evidence from any extensive study that legislation enacted by initiative is . . . more "biased" . . than the workproduct of the legislative branch"); see also Briffault, supra note 19, at 1364 ("greater [legislative] potential for attentiveness to minority groups has not always been matched in practice" (emphasis in original)). But see Bell, supra note 4, at 1 ("experience of blacks . . . has proved . . . that the more direct democracy becomes, the more threatening it is" to unpopular minorities).

214. Indeed, the task of comparison seems Herculean. Plebiscites number in the thousands annually. Legislative product no doubt can be counted in the millions. Moreover, there are substantial variations in experience from state to state, and from locality to locality even within a single state. Finally, the passage of every ballot measure is influenced by a myriad of factors, and broad-based comparisons run the risk of papering over these complexities. As one of the earliest students of the initiative process observed: "How superficial at best must be our insight into that complex of social, political, economic and human forces which lay back of the presentation of [the measures voted on in 1914] and the popular decision upon them." Cushman, Recent Experience with the Initiatite and the Referendum, 10 AM. Pol. ScI. Rev. 532 (1916).

215. Sep Allen, supra note 18, at 1014 (studies of performance of initiative process tend to be dated and methodologically suspect); see also Sirico, supra note 22, at 641 (social science literature does not indicate whether minorities have done better with legislatures than with voters). Professors Thomas Cronin and David Magleby have each recently completed extensive studies of direct democracy. Cronin finds voters no more prone to impair equality, T. CRONIN, supra note 16, at 92, 98, while Magleby concludes that legislatures are more sensitive to the interests of minorities, $D$. MAGLEBY, supra note 16, at 184-85. In books otherwise loaded with empirical data these particular conclusions rely only on general observations. Perhaps Clayton Gillette is correct when he states that claims about comparative performances of direct and representative democracy are not capable of empirical demonstration. Gillette, supra note 19 , at 938 .

216. This focus leaves much majority tyranny unseen. In November 1989 , for example, an election with almost no controversial statewide measures, the voters of Seattle voted to make additional tax revenues available to the school district only if the School Board reversed its decision to bus students for racial balance, see N.Y. Times, Nov. 15, 1989, at A18, col. 6 (West Coast edition), and the voters of three California cities repealed local legislative measures enacted for the protection of the gay and lesbian community, see L.A. Times, Nov. 9, 1989, at A1, col. 1.

217. Allen, supra note 18 , at 1008 . 
There are two distinctive components to assessing substitutive democracy's relative capacity for majority tyranny. The first concerns the need for filters. The second deals with their efficacy.

\section{a. The Need For Filters}

Advocates of direct democracy frequently invoke a trust in the inherent goodness and fairness of the citizenry. All criticisms, Benjamin Barber informed the Senate, "are so many different ways of saying 'the people are not to be trusted.' "218 Representative Walter Fauntroy prefers "to put my faith in the good judgment of the American people and in their basic good." ${ }^{219}$ White voters will respond to the plight of blacks, ${ }^{220}$ the middle class will not cut off the poor, ${ }^{221}$ and the Bill of Rights will remain intact. ${ }^{222}$

Many of us, however, are not prepared so confidently to shed the skepticism of the Founders. It may be politic to invoke an abiding trust in public judgment, but racism, sexism, nativism, and self-interest are too much a part of American history to be ignored. In a multitude of ways we continue to demonstrate our fear of the other and our distrust of difference. While public proclamations of racist attitudes have lost their respectability, prejudice continues to receive an airing in the privacy of the voting booth. ${ }^{223}$ As Charles Black once reminded us, the very definition of unpopularity is that unpopular groups normally will fare poorly at the ballot box. ${ }^{224}$

A recent Gallup Poll asked those surveyed whether they believed the opinions of minority groups would "get a fair say" among citizens asked to vote directly on legislation. Fifty-eight percent thought so. Thirty-two percent thought not. Among non-whites the figures were quite different. The respondents split evenly, with forty-six percent believing that minori-

218. See Hearings, supra note 14 , at 195.

219. Id. at 34.

220. Walter Fauntroy has expressed the belief that matters involving civil rights, voting rights, and affirmative action "would be faced and responded to at least as courageously by the majority of the American voting public as the Congress has faced and responded to issues surrounding the plight of various minority segments of our population." Id. at 35. Had a national initiative process been in place at the time of the Civil Rights Bill of 1964, says Fauntroy, "the result would have been the same, perhaps even stronger." Id. at 38.

221. Id. at 72 (Testimony of Professor Larry Berg). Shortly after Professor Berg testified, California adopted Proposition 13.

222. Sie Amar, supra note 2, at 1096-97. Amar, however, does suffer a partial loss of faith when it is trust in the people of a state rather than the nation as a whole that is being debated. Id. at 1097.

223. Sie K. Karst, Belonging to America 274 n.32 (1989); Pettigrew, New Palterns of Racism: The Different Worlds of 1984 and 1964, 37 Rutgers L. REv. 673, 691 (1985); see also Crenshaw, Race, Reform, and Retrenchment: Transformation and Legitimation in Antidiscriminatom Lau", 101 Harv. L. REv. 1331, 1347 n.62 (1988) ("Polls show that most Americans have adopted the rhetoric of formal racial equality" while expressing anti-Black opinions on issues such as miscegenation and housing integration). On occasion the Court has demonstrated sensitivity to the prejudice which permeates the voting booth. See Anderson v. Martin, 375 U.S. 399 (1964) (law requiring designation of candidate's race on ballots held unconstitutional).

224. Black, supra note 19 , at 31 . 
ties would not get fair treatment at the hands of the voters and the same percentage registering faith in electoral fairness. ${ }^{225}$ Even if the public judgment often turns out to be "fair" to minorities-whatever that means-at least a perception exists among a substantial percentage of Americans, especially minorities, that it is not.

Perhaps most telling is the ultimate lack of faith in the unfiltered judgment of a simple majority shown by the very people who praise the electorate's track record and chide us for our distrust. Benjamin Barber concludes his primer for participation by worrying about "whimsical majorities" and suggesting multiple votes and legislative or executive vetoes-subject to subsequent override-as checks against majorities working their will without prolonged debate and deliberation. The aim "is not to make it easy for the public to self-legislate but to make it possible."226 His particular brand of strong democracy calls for adding participatory ingredients to the constitutional formula, not removing representative ingredients. Checks and balances must, according to Barber, be kept in place to prevent majorities from running roughshod over minority expressions of dissent and indignation. ${ }^{227}$ Ron Allen ends his brief for a national initiative by endorsing a super-majority requirement "as an awkward attempt to provide institutional protection for minority interests." ${ }^{228}$ Both Richard Briffault and Clayton Gillette defend direct democracy while noting the comforting presence of a sturdy judicial safety net. ${ }^{229}$ And Thomas Cronin hedges his tribute to the plebiscite's track record by acknowledging that "[i]f we are to give occasional free rein to majority rule at the ballot box, we shall have to give additional consideration to protecting the rights of minorities." ${ }^{\text {230 }}$ The message these commentators leave us is this: Those who oppose electoral lawmaking lack the trust in the people that a democracy demands. But trust only goes so far. In the end simple majorities cannot be expected consistently to honor the interests of minorities and guarantee individual liberties. Something more is needed.

I must admit to a degree of confusion. If indeed the electorate-without a checking structure - has done as well by minorities and individual rights as the legislature has, does it not suggest that checks are unnecessary? Yet no one seems to endorse this conclusion. No one is willing to leave all decision-making to mere aggregation of electoral preferences. This of

225. See T. Cronin, supra note 16, at 98-99. The specific breakdown between whites and nonwhites is on file with the author.

226. B. BARBER, supra note 19 , at 288 (emphasis in original).

227. Id. at $308-11$.

228. Allen, supra note 18 , at 1043 . Allen proposed that passage require a majority in a majority of states. 1 refer to this as a super-majority requirement to distinguish it from a simple-majority vote. Allen apparently rejects such a label. Id. at 1045 .

229. See Briffault, supra note 19, at 1364-65 (judicial review ensures that direct legislation no more threatens minorities than does legislature); Gillette, supra note 19, at 984 (courts can check plebiscites as they do legislature).

230. T. Cronin, supra note 16 , at 98 . 
course is consistent with the premise of our Constitution. If it does not mean that the champions of substitutive democracy lack trust in electoral majorities, it at least means that they demand certain conditions to ensure that trust is warranted. In the end, their distrust, like mine, is of the process not the people. Considered judgments, sensitive to the interests of all, require time, debate, deliberation, information, and shared power. Substitutive plebiscites shortchange the decision-maker on all these accounts.

\section{b. The Efficacy of Filters}

The legislative process, whether described as deliberative or pluralist, affords minority groups a role that they lack in the substitutive plebiscite.

Our worst tendencies toward prejudice, suggests Derrick Bell, are chastened in legislative debate. ${ }^{231}$ Knowledge and exposure are effective weapons against prejudice. Debate and deliberation inevitably lead to better informed judgment. Enlarging one's exposure to competing ideas and perspectives induces greater sensitivity and checks partiality. ${ }^{232}$ Legislative hearings and the testimony of various interest groups widen the legislator's horizon. But hearings are only a part of legislative education. Perhaps a more important factor in generating empathy is the diversity of the legislature's membership itself. Racism is not always conscious. More often than not it occurs because of ignorance, oversight, or insensitivity. When minorities are part of the legislative "we," subordination of the "other" becomes both more visible and less comfortable. Group representation ensures that diverse views are continually expressed, increasing "the likelihood that political outcomes will incorporate some understanding of the perspectives of all those affected." 233

The substitutive plebiscite, on the other hand, has little capacity for deliberation. ${ }^{234}$ Public debate is infrequent. Exposure to minority perspec-

231. Bell, supra note 4, at 29. Professor Bell believes only that prejudice is subdued in the deliberative enviranment. He holds out little hope for its elimination. See Bell \& Bansal, The Republican Rivizal and Racial Politics, 97 YALE L.J. 1609, 1612 (1988) (Blacks properly feel "skepticism and cynicism" when asked "to rely on a theory that extols the shared values of a deliberative model").

232. See J. RAwLS, A THEORY OF Justice 358-59 (1971) (exchange of opinion checks partiality and widens perspectives; "[W]e are made to see things from the standpoint of others and the limits of our vision are brought home to us.").

233. Sunstein, supra note 84 , at 1588 . This of course assumes a diverse legislative body. In a system of at-large rather than proportional representation this benefit will be lost. See City of Mobile v. Bolden, 446 U.S. 55, 123 (1980) (Marshall, J., dissenting) (at-large voting effectively locks discrete political minorities out of governmental decisionmaking processes).

234. See D. MÁALEBY, supra note 16, at 187 (voters appear to decide with little deliberation or discussion); Black, supra note 19, at 30-31 (initiative process does not permit informed deliberation such as normally" engaged in by legislature); Sager, supra note 144, at 1414 ("Legislation by plebiscite is not and cannot be a deliberative process."); see also Michelman, supra note 99, at 185 (directdemocratic procedures used sporadically in large and politically apathetic electorates do not fulfill Rousseau's vision of deliberative community expressions of the general will). One commentator disagrees, claiming that "the deliberative process that informs legislators has an equivalent in the plebiscitary process." Gillette, supra note 19 , at 958 . Gillette's claim is a bit unusual. He argues that most 
tives occurs accidentally if at all. Voters may be confused and overwhelmed by the issues placed before them. ${ }^{235}$ Any efforts at self-education are thwarted by manipulative campaigns designed to oversimplify the issues and appeal to the electorate's worst instincts. ${ }^{236}$ Most important, voters register their decisions in the privacy of the voting booth. They are unaccountable to others for their preferences and their biases. Their individual commitment to a consistent and fair course of conduct can be neither measured nor questioned.

If the deliberative version of the legislative process sounds a little too much pie-in-the-sky to the reader, I share the sentiments. Whatever its normative force, it falls considerably short as description. The deviations from an ideal model of deliberation are particularly marked at the state and local level. And it is to combat this failing that many commentators have urged judicial emphasis on due process of lawmaking. ${ }^{237}$ But it seems inconceivable that on balance the legislature does not come a whole lot closer to the ideal than the substitutive plebiscite. ${ }^{238} \mathrm{~A}$ pluralistic snapshot of the legislative process shows an ongoing system of compromise, negotiation, vote-trading and tactical deals. This arrangement forces legislators to reckon with minority groups. Legislative logrolling over a broad agenda brings minorities into the process and allows resulting compromises to accommodate their interests. ${ }^{239}$

Substitutive plebiscites, on the other hand, are one-shot, winner-takeall. The coalition process does not work in the sporadic and unwieldy world of citizen lawmaking. As Frank Michelman notes, you can't dicker with an electorate for support now in exchange for your support on something else later. ${ }^{240}$ Majoritarian preferences cannot be softened or diluted by political compromise.

persons will not vote, id. at 946 , that the process of voting serves as a filter for those who have thought about the underlying issues, $i d$. at 958 , and that those who opt for participation thus do so deliberatively, id. at 960 . Gillette's claim, while imaginative, has two shortcomings. On a general level, his notion of an informed electorate appears to be flatly contradicted by a number of surveys. See supra text accompanying note 46. More darnaging in the particular context I address here, however, is his failure to take account of the racial, class, and financial skew of those who vote on ballot propositions. See supra notes 43-44. If Gillette's sighting of deliberation is accurate, it is not likely to be the sort of deliberation that will result in attention to the voices at the margin.

235. See supra notes $46-50$ and accompanying text. A 1989 Pennsylvania ballot measure on tax reform ran 125 pages. See Famliy, Law \& Democracy Report, June 1989, at 1. Small wonder that voters are confused.

236. See supra notes $51-53$ and accompanying text.

237. E.g., Sunstein, supra note 89; J. ELY, supra note 86, at 125-34; L. TRIBE, supra note 28, at $1673-87$.

238. Thus, although commentators like Richard Briffault criticize critics of direct democracy for "overstating" the deliberative nature of the legislative process, see Briffault, supra note 19, at 1362, they usually end up conceding that it is "likely" that the legislative process has "a greater potential for deliberative decision making than does initiative voring." Id, at 1363.

239. See J. Buchanan \& G. Tullock, The Calculus of Consent 133 (1962) (if minorities are represented in legislature, log-rolling will block laws discriminating against them). But see $\mathrm{R}$. Sugden, The Political, Economy of Public Choice 184 (1981) (log-rolling no defense against injustices of majority rule).

240. Michelman, supra note 99, at 182; see also D. MAGleBY, supra note 16, at 184 (direct 
It is not the continuing and open nature of the legislators' relationship alone that blunts majoritarian excess. Three features of the legislative structure magnify the minority voice. First, the committee system disproportionately empowers minorities and necessitates bargaining in order to "move" legislation. Second, political parties assert a strong antimajoritarian influence in the legislative process by enabling the individually powerless to aggregate their voting power ${ }^{241}$ Political parties play a minimal role in the substitutive plebiscite. ${ }^{242}$ They rarely take a stand on ballot measures, leaving confused voters to rely on individual politicians for external cues. Third, and perhaps most resonant of the Framers' plan is the part played by bicameralism and executive veto. Bicameralism forces majorities to seek broader coalitions. It imposes something like a supermajority voting rule. ${ }^{243}$ The executive veto not only affords minority groups an additional ear on legislation that affects them, but because legislative override demands supermajority votes, the veto also enhances minority currency.

Pluralism in the legislative process is a two-edged sword. Minoritarian counterweights have undesirable costs to accompany their benefits. The same mechanisms that allow less advantaged minorities to check the legislative product permit plutocratic interests to exert disproportionate influence. Indeed, because these groups are better organized and better financed, interest group politics tends to skew dramatically in their

legislation excludes compromise and accommodation); Black, supra note 19, at 31 (initiative compels total polarization); Note, supra note 98 , at 1304 n.111 (transaction costs of coalition-building and logrolling for minority groups are much lower in legislature than in polity at large). Derrick Bell makes the apt analogy to at-large voting. See Bell, supra note 4, at 25-26 (plebiscites, like multi-member districts, tend to minimize or cancel out voting strength of racial and political minorities). Clayton Gillette argues that compromise does play a role in the plebiscitary process. The drafters of initiatives, te contends, understand the yes-no choice open to the voters, and in order to attain sufficient support they may construct a form more moderate than the one favored by the most zealous advocates. Thus compromise, absent from the voting stage, is built in at the drafting stage. Gillette, supra note 19, at 969-70. All this proves, however, is that initiatives with only minority support have to be softened. Those with solid majority backing need make no accommodations for minorities. Indeed, to do so may erode support among the majority.

241. Set W. BURNhaM, supra note 41, at 294 (Democratic party often embraces public policies with little general mass support); W. CrotTy, American Parties in Decline 281 (2d ed. 1984) (political parties "most effective vehicle" for representing "out-groups"); K. KARST, supra note 223, at 93 (political parties "connect different groups," and "party activity makes cultural subgroups feel like insiders"); V. Key, Jr., Southern Politics in State and Nation 298-311 (1949) (Democratic party functions as bargaining agent among conflicting minority interests); R. LANE, POLITICAL. Life: Why People Get INvolved in Polrtics 270 (1959) (disorganized and resourceless groups need political ties to mobilize). Some historians contend that a major purpose behind the adoption of initiative procedures was to reduce the power of party machines and of the lower and middle class groups to which they catered. See, e.g., S. HAys, supra note 38, at 217-29.

242. As David Magleby points out, the parties usually play no role in the drafting of initiatives and are thus-robbed of their traditional role of "weighing competing interests, achieving compromise, and moderating demands in order to appeal to the maximum number of voters." D. MAGLEBY, supra note 16 , at $18 \%$.

243. Se' J. Buchanan \& G. Tullock, supra note 239, at 233-48. Bicameralism, however, plays a lesser role on the state and local level than on the national level. Although every state but Nebraska has retained the bicameral form, nearly all major local governments today have unicameral legislatures. Sie T. CRONIN, supra note 16, at 33. 
direction. ${ }^{244}$ But for both groups, the enhanced voice produces minoritarian vetoes far more than minoritarian legislation. ${ }^{245}$ The added advantage tends to be a negative power rather than an affirmative one. This after all is how the Framers intended the filtering system to work. The upside would be a limit on simple majoritarianism. The downside would be impasse.

It was precisely the ability of narrow political and economic interests to block popular legislation that led to the adoption of the substitutive plebiscite. $^{246}$ A good deal of what this reform produced has been positive. When powerful private interest lobbies cause legislative inattention to the public interest, initiatives serve a valuable corrective function. The problem is that circumventing counter-majoritarian influences indiscriminately breaks the stranglehold of special economic interests ${ }^{\mathbf{2 4 7}}$ and stifles the voices of unpopular racial and political minorities. If we are to reap the rewards of the former, we must provide compensation for the latter.

\section{The Outlines of a Hard Judicial Look}

The purpose of this article is to suggest that courts take a harder look when constitutional challenges are mounted against laws enacted by substitutive plebiscite. In a sense I am proposing a new paragraph for the Carolene Products footnote: a fourth situation where the presumption of

244. See K. Schlozman \& J. Tierney, supra note 201, at 66-87, 107-19. The authors nonetheless acknowledge that less advantaged groups are "heeded in the making of policy." Id. at 403.

245. See supra note 122; see also Farber \& Frickey, supra note 65, at 906 (social science literature indicates that interest groups exercise more power when they oppose legislation than when they support it).

246. See T. Cronin, supra note 16 , at 45 (direct democracy became appealing as populists saw legislatures defeat proposals majority favored); Briffault, supra note 19, at 1364 (initiative designed iu offset minority influence when legislature failed to act on program desired by majority); Lowenstein, Califormia Initiatites and the Single-Subject Rule, 30 UCLA L. REv. 936, 965 (1983) (function of initiative is to check narrow political and economic interests).

247. It is not clear that direct democracy has been successful in this regard. See generally Lowenstein, supra note 27 , at 570, 576 (by one-sided spending, special interests-usually business corporations or trade associations-can block passage of initiative favored by majority). The power of wellfinanced groups to oppose ballot propositions successfully without regard to any breadth of popular feeling seriously interferes with the substitutive plebiscite's intended purpose. Id. at 608. Clayton Gillette takes great delight in exposing what he believes are conflicting criticisms of the plebiscite: (1) that it ignores the interests of the minority, and (2) that it can too easily be captured by special interests. He takes Derrick Bell to task for being "oblivious" to the inherent conflict between the two. Gillette, supra note 19, at 936-37. But it is Gillette who seems oblivious in his assumption that the "small, organized interests" capable of capturing the plebiscite process are the same category of "minority" that Bell is worried about being neglected by electoral majorities. In a system where just gathering the required signatures to get on the ballot can cost upwards of $\$ 1$ million, and where the amount expended in California's November 1988 initiative battle over insurance reform eclipsed the amount spent nationwide by Michael Dukakis and George Bush, see Wolinsky, \$23 a Vote, L.A. Times, Mar. 31, 1989, at 3, col. 1, the poor and racial minorities will be doing little capturing. The majority may not always win the plebiscite, but if it is thwarted, financially empowered minorities will do the thwarting. Ironically, the very same "contradiction" that Gillette sees in Bell's fears traces to ThE FEDERALIST No. 10, at 57 (J. Madison) (expressing fears of factions, whether majority or minority). 
constitutionality should be relaxed. ${ }^{248}$ On occasions when the people eschew representation, courts need to protect the Constitution's representational values. This approach might be called representation-enforcement in contrast to John Ely's representation-reinforcement model for review of legislative efforts. Where the structure itself is unable to guarantee a hearing for a variety of voices or to prevent factional domination, courts must pick up the slack and ensure that the majority governs in the interests of the whole people.

I shall not attempt here to provide a detailed primer for judicial application of such an intensified review. Substitutive plebiscites cover a dazzling array of subject matters ${ }^{248}$ and are challenged under a variety of specific constitutional provisions, including equal protection, impairment of contract, First Amendment ${ }^{250}$ taking without just compensation, cruel and unusual punishment, and procedural due process. With all signs advising caution, I nonetheless cannot resist a number of general suggestions.

Because the harder look is prompted by a concern for individual rights and equal application of laws, it is principally in these areas that the courts should treat substitutive plebiscites with particular suspicion. Where, on the other hand, the electorate acts to improve the processes of legislative representation, the justification for judicial vigilance is absent. Measures to enforce ethics in government, ${ }^{251}$ regulate lobbyists, ${ }^{262}$ or re-

248. See 304 U.S. 144, 152 n.4 (1938) (citations omitted):

There may be narrower scope for operation of the presumption of constitutionality when legislation appears on its face to be within a specific prohibition of the Constitution ....

[L]egislation which restricts those political processes which can ordinarily be expected to bring about repeal of undesirable legislation . . . [may] be subjected to more exacting judicial security. . . . [Strict scrutiny may also apply to] statutes directed at particular religious, or national, or racial minorities....

Instead of viewing review of substitutive plebiscite as a "fourth situation," it might be possible to fit it under the second or third identified by Justice Stone-substitutive plebiscites both clog the channels of political change (paragraph 2) and "curtail the operation of those political processes ordinarily to be relied upon to protect minorities" (paragraph 3). See Comment, Judicial Revieu of Lau' Enacted by Popular Vote, supra note 4, at 204-06. Because it is clear that Stone had only the legislative process in mind, however, I prefer to supplement his list rather than to distort it.

249. Recent initiatives have addressed subjects as diverse as public morality, governmental processes, taxation, labor regulation, business regulation, utility rates, zoning and land use, health, welfare reform, housing, homelessness, education, civil rights, environmental protection, and nuclear power. For a listing of the November 1988 plebiscites grouped by subject matter, see 9 INITIATIVE AND REFERENDUM REPORT, supra note 50, at 19-24.

250. For an interesting perspective on the intersection between First Amendment theory and judicial review of plebiscitary action affecting free speech, see Schauer, The Role of the People in First Amendment Theory, 74 CALIF. L. REv. 761, 779-80, 783-85 (1986) (Meiklejohnian theory of First Amendment, dependent on popular sovereignty, gives substantial weight to views of electorate regarding speech issues).

251. Sep, e.g., FLA. ConsT. art. II, $\S 8$ (requiring full financial disclosure by state and county officials and candidates; enacted by voter initiative in November 1976); see also Fritz v. Gorton, 83 Wash. 2d 275, 517 P.2d 911 (1974) (upholding public disclosure initiative). A recent example is the successful November 1988 Arkansas statutory initiative strengthening rules of legislative ethics and requiring enhanced legislative disclosure of dealings with lobbyists. See 9 INITIATIVE AND REFERENDUM REPORT, supra note 50, at 18.

252. E.g., California's Political Reform Act of 1974, CAL. Gov'T ConE, \$§ 81000-91015 (West 
form campaign finance practices ${ }^{253}$ pose no distinctive threat of majoritarian tyranny. These measures install new filters rather than seeking to bypass the existing ones. Interestingly enough, only one of the nearly three dozen plebiscites reviewed by the Supreme Court has involved such a measure. ${ }^{254}$

I am unwilling, however, to group alterations of government structure and reapportionment efforts in the category of governmental reform. Too often these "reforms" are a facade for disfranchising minorities; courts should be watchful of such chicanery. ${ }^{205}$ Neither do I ignore the threat of majority tyranny in fiscal measures like taxation and spending limitations. The beneficiaries of these so-called taxpayer revolts are principally upper and upper-middle class white citizens. The brunt of the burdens, in contrast, is borne by the underrepresented poor and by racial minorities. ${ }^{256}$

1987) (voter initiative requiring lobbyists to register and to disclose transactions, and restricting their ability to make gifts and political contributions). The California Supreme Court subsequently invalidated the contribution ban and many of the reporting requirements on the theory that they impinged on the lobbyists' First Amendment rights. See Fair Political Practices Comm'n v. Superior Court, 25 Cal. 3d 33, 599 P.2d 46, 157 Cal. Rptr. 855 (1979). Like the United States Supreme Court, the Galifornia court seems hesitant to allow abridgement of speech in order to enhance the representative process. Rulings such as Fair Political Practices Commission either are insensitive to the impact of the inequality of resources on the operation of government, see supra note 163, or regard such inequalities as an inevitable part of American life that government may not "remedy." When voters move in an egalitarian direction to open up political channels-as California voters appear to have done in 1974-the initiative operates in the best traditions of the Constitution's representational values, and Justice Black's call for enhanced judicial deference is at its most compelling. Further, popular action directed at making government officials more responsive to their constituents augments rather than threatens the checking function of the First Amendment. $C f$. Schauer, supra note 250 , at 782 (electoral delineations of free speech rights must be assessed in context of substantive theory of First Amendment that one embraces).

253. Again, the California Political Reform Act of 1974 provides an apt example. Chapter 5 of that initiative placed limits on campaign spending. Under what it perceived as the compulsion of Buckley v. Valeo, 424 U.S. 1 (1976), the California Supreme Court struck down several of the limitations. See, e.g., Citizens for Jobs \& Energy v. Fair Political Practices Comm'n, 16 Cal. 3d 671, 547 P.2d 1386, 129 Cal. Rptr. 106 (1976) (voiding aggregate expenditure limitations on supporters and opponents of statewide ballot propositions). The factors that counsel against enhanced review of lobbyist regulations challenged under the First Amendment, see supra note 252, are equally applicable here.

254. See Citizens Against Rent Control v. Berkeley, 454 U.S. 290 (1981). In that case the Court struck down a municipal initiative imposing a $\$ 250$ limitation on contributions to committees formed to support or oppose ballot measures. Whatever the correctness of the Court's decision, plebiscites like this do not warrant enhanced judicial suspicion. See supra note 252.

255. The Supreme Court has been willing to acknowledge only the most patent such trickery. Sre, e.g., Hunter v. Erickson, 393 U.S. 385 (1969) (invalidating popular referendum changing city charter to require voter approval of open housing ordinances); Washington v. Seattle School Dist. No. 1, 458 U.S. 457 (1982) (voiding initiative altering powers of local school boards); see also Lucas v. FortyFourth Gen. Assembly, 377 U.S. 713 (1964) (striking down voter-adopted reapportionment scheme). When the disfranchisement effort has been more subtle, the Court has seemed blind to the motivations prompting the plebiscite's structural alterations. See, e.g., James v. Valtierra, 402 U.S. 137 (1971) (upholding voter amendment to state constitution requiring voter approval for low-income housing projects on ground that it involved no racial distinctions); City of Eastlake v. Forest City Enters., 426 U.S. 668 (1976). Eastlake upheld a plebiscite making zoning changes more difficult, a change that an Ohio Supreme Court Justice described as designed "to perpetuate the de facto divisions in our society between black and white, rich and poor." Forest City Enters. v. City of Eastlake, 41 Ohio St. 2d 187, 200-01, 324 N.E.2d 740, 749 (1975), rev'd, 426 U.S. 668 (1976).

256. Derrick Bell suggests that the success of California's initiative limiting property taxes-Proposition 13-may in part be attributed to voter belief that approval would result in reduced 
This raises the problematic question of how to measure discrimination against minorities. The traditional approach holds that "the invidious quality of a law claimed to be racially discriminatory must ultimately be traced to a racially discriminatory purpose."257 Disparate impact on acknowledged minorities without more does not suffice to invite close judicial scrutiny. The search for a bigoted decision-maker seems particularly elusive in the context of substitutive plebiscites. Public debate is minimal and voting is private. Furthermore, lower courts have barred inquiry into motivations of individual voters.

According to a unanimous panel of the United States Court of Appeals for the Fifth Circuit, the First Amendment "assures every citizen the right to 'cast his vote for whatever reason he pleases.' " Racial prejudice, while "neither socially admirable nor civically attuned, [is] not constitutionally proscribed."258 The Fifth Gircuit is not alone in creating insurmountable obstacles to minorities' raising equal protection challenges to voter efforts. Judge Cornelia Kennedy, the author of a recent unanimous opinion of the Sixth Circuit, explicitly barred inquiry into electoral motivation unless racial discrimination is the only possible motivation behind the referendum results. ${ }^{258}$ She offered two justifications for this rigid prohibition. First, the secret ballot had to be protected. "Since a court cannot ask voters how they voted or why they voted that way, a court has no way of ascertaining what motivated the electorate." ${ }^{260}$ In this way, cases permitting inquiry into the votes of legislators were inapposite. Second, although the record before her revealed some racial slurs uttered in meetings leading to the referendum, Judge Kennedy refused to infer racial bias in the total electorate, noting that courts should "not lightly set aside the results of voter referendums." If inquiry into the racial motivation of voters were allowed, she feared, opponents of ballot measures would be encouraged to introduce race as an issue in every election affecting minorities. ${ }^{261}$

Surely there is something faulty with this reasoning. Perhaps the Fifth Circuit has it technically right when it concludes that individual citizens are "entitled" to vote for the basest motives imaginable. ${ }^{262}$ Judge Kennedy is no doubt correct that in any event we can neither discover nor prevent

welfare payments by the state. See Bell, supra note 4 , at 19 n.72.

257. Washington v. Davis, 426 U.S. 229, 237 (1976).

258. Kirksey v. City of Jackson, 663 F.2d 659, 662 (5th Cir. 1981).

259. See Arthur v. City of Toledo, 782 F.2d 565, 574 (6th Cir. 1986).

260. Id $d_{*}$ at 573 ; accord Southern Alameda Spanish Speaking Org. v. Union City, 424 F.2d 291, 205 (9th Cir. 1970) (probing of voters' motives "would entail an intolerable invasion of the privacy that must protect an exercise of the franchise").

261. Arthur, 782 F.2d at 573.

262. Kirksy, 663 F.2d at 662. Lawrence Sager puts the claim more sympathetically. We would, Sager points out, reject a challenge to a mayoral election on the ground that the voters favored candidate $\mathrm{X}$ because his opponent was black, even if the fact of the racial animus were firmly established. "This solicitude for the sanctity of individual choice in the electoral context," Sager concludes, "logically extends to legislative plebiscites." Sager, supra note 144 , at 1421. 
the casting of such votes. But the very recognition of the fundamental way in which a voter's responsibility differs from a legislator's constitutional obligation, as well as the inevitable evidentiary obstacles to assessing electoral motivation, demands a different judicial treatment of the law produced by the electorate. As the Supreme Court noted in Palmore v. Sidoti, "[p]rivate biases may be outside the reach of the law, but the law cannot . . give them effect." ${ }^{\text {"283 }}$

Two approaches are possible. We may relax the burden of proving discriminatory purpose and be more imaginative about the sources we canvass-for example, ballot pamphlets, exit polls, campaign advertising ${ }^{284}$ - or we may abandon the purpose requirement altogether in certain plebiscitary settings. ${ }^{268}$

A patchwork of the two approaches can be observed in Washington $v$. Seattle School District No. $1 .^{268}$ The case arose out of the efforts of Seattle school authorities to achieve racial balance by involuntary busing. A group of Seattle residents who opposed "The Seattle Plan" introduced an initiative (Initiative 350) to prohibit school districts from "requir[ing] any student to attend a school other than the school which is geographically nearest or next nearest the student's place of residence."287 A number of exceptions permitted student reassignment to alleviate overcrowding or to meet special educational needs of individual students. At the November,

263. 466 U.S. 429, 433 (1984); see also City of Cleburne v. Cleburne Living Center, 473 U.S. 432, 448 (1985) (electorate as a whole cannot by referendum order government action violative of equal protection clause).

264. See Bell, supra note 4 , at $24 \mathrm{n} .91$ (public opinion polls, advertising campaigns, or even statements by supporters might be used to show discriminatory purpose). But see Crawford v. Board of Educ., 458 U.S. 527, 545 (1982) (where nondiscriminatory objectives stated in text of ballot proposition, Court will ordinarily not "impugn the motives of the State's electorate"). A recent student note exploring the somewhat different problem of statutory interpretation argues that popularly enacted legislation "produces a wealth of extrinsic materials that can serve as evidence of the intent of the electorate." Note, The Use of Extrinsic Aids in the Interpretation of Popularly Enacted Legislation, 89 Colum. L. REv. 157, 164 (1989). But these "extrinsic materials," which include voter pamphlets, statutory statements of intent, and voter exit polls have serious limitations when racial motivations are the subject of inquiry. Statements of intent and ballot pamphlet explanations will seldom sound the publicly unacceptable voice of bigotry. Further, ballot pamphlets are "campaign documents, drafted for tactical purposes with the uncommitted voter in mind, and therefore do not necessarily reflect the intent of either the authors of a proposition or the greater number of persons who vote for it." Lowenstein, supra note 246 , at 954 n.73. Finally, most voters will not have read, let alone understood this material. See supra notes $21,44-50$, and accompanying text. The privacy of opinions ventured to pollsters and the crassness of campaign advertising hold greater promise of ferreting out impermissible motives. But methodologically sound polls will not always be available, and courts are unlikely to assume that voters were swayed by scurrilous ad pitches. As Jesse Choper concludes, it will be a real challenge to courts to determine what sort and what quantum of evidence will be necessary to demonstrate illicit motivation in the plebiscitary context. See J. Choper, Y. Kamisar \& L. TRIBE, supra note 4 , at 243.

265. One commentator calls for dispensing with a purpose inquiry whenever plebiscites are challenged under the equal protection clause. See Gunn, Initiatizes and Referendums: Direct Democracy and Minority Interests, 22 URB. L. ANN. 135, 158-59 (1981) (proposing that disproportionate impact on minorities trigger strict scrutiny of citizen lawmaking).

266. 458 U.S. 457 (1982).

267. Id. at 462 (quoting initiative). 
1978, general election, the proposal received nearly two-thirds of the statewide vote. A constitutional challenge followed.

A Federal district judge held Initiative 350 unconstitutional based on his conclusions that (1) it facially classified according to race and, alternatively, that (2) even if facially neutral, it had been adopted for discriminatory purposes. ${ }^{268}$ In reaching the latter conclusion, the judge acknowledged that the secret ballot raised an "impenetrable barrier" to determining whether the initiative's supporters "subjectively [had] a racially discriminatory intent or purpose,"269 and he conceded that the initiative's proponents had not "directed [their] appeals to the racial biases of the voters." ${ }^{\text {270 }}$ Nonetheless, he found that the racially disproportionate impact of Initiative 350, when coupled with its historical background, the sequence of events leading to its adoption, and its departure from Washington's procedural norm of local school board autonomy, demonstrated "that a racially discriminatory intent or purpose was at least one motivating factor in [its] adoption."271

A sharply divided Supreme Court agreed that Initiative 350 was unconstitutional. The majority's route to that conclusion, however, cannot easily be mapped. Initially, Justice Blackmun's opinion appears to reject the trial court's characterization of the initiative as a facial classification, choosing instead to note its "facial neutrality."272 Nevertheless, he acknowledges, the "reality is that the law's impact falls on the minority."273 Under case law, however, disparate impact without more is not sufficient to trigger strict scrutiny-something the initiative's sponsors reminded the Court at every turn. The Court's response to this obstacle is confused. At times, Justice Blackmun appears to find impermissible motive, noting that "there is little doubt that the initiative was effectively drawn for racial purposes," a fact of which the Washington electorate was "surely . . . aware." ${ }^{274}$ Elsewhere in the opinion, he seems to be saying that where the normal decision-making process is altered for issues of unique interest to minority groups, inquiry into motivation is not necessary. ${ }^{275}$ Just when

268. Seattle School Dist. No. 1 v. State, 473 F. Supp. 996, 1011 (W.D. Wash. 1979). The district judge offered yet a third justification for voiding the initiative-that it was overbroad because it barred the school board from implementing mandatory student assignment programs even when the board had a constitutional duty to eliminate segregation. $I d$.

269. Id. at 1013-14.

270. II, at 1009 .

271. Id. at 1014-16.

272. 458 U.S. at 471 . An excellent critique of the Seattle decision to which $I$ am indebted is Sunstein, Public Values, Private Interests, and the Equal Protection Clause, 1982 Sup. CT. REv. 127.

273. Srallle, 458 U.S. at 475 (quoting from Hunter v. Erickson, 393 U.S. 385, 391 (1969)); see also id. at 480 n.23 ("what we find objectionable about Initiative 350 is the comparative burden it imposes on minority participation in the political process" (emphasis added)).

274. Id. at 471; see also id. at $486 \mathrm{n.30}$ ("IS]ingling out the political processes affecting racial issues for uniquely disadvantageous treatment inevitably raises dangers of impermissible motivation.").

275. Id. at 485 (relying on Hunter *. Erickson). 
we take Justice Blackmun to be carving out some kind of third category between facially discriminatory statutes that demand no showing of purposefulness and facially neutral laws that do, he appears to abandon his earlier description of Initiative 350 as facially neutral and to characterize it as a racial classification. ${ }^{278}$

The majority opinion in Seattle thus provides some support for each of three readings: (1) the initiative constitutes a facial classification based on race; (2) the initiative is facially neutral but triggers strict scrutiny since it was purposefully enacted "because" of its adverse impact on minorities; or (3) the initiative falls into a twilight zone of laws altering the structure of decision-making, where the Court will subject a facially neutral law to strict scrutiny-even absent proof of purposefulness-because of the comparative burden it imposes on minority participation in the political process.

As inartful as the Seattle opinion may be, the Court's intuition that Initiative 350 deserved to be approached with more than the usual suspicion was well founded. The Seattle School District had historically made considerable efforts to alleviate the isolation of the district's sizable minority population. Local attempts to recall the Board members responsible for some of these efforts had narrowly failed. ${ }^{277}$ The sponsors of Initiative 350 therefore opted to circumvent the representative process that produced the reassignment plan. The filtering system had trapped the majority's worst inclinations and the initiative process afforded an opportunity to bypass the filters.

The Seattle majority undoubtedly sensed this, but the Justices had two problems. First, the Court's precedents offered no easy way to invalidate the initiative. In no conventional sense of the word could the Washington measure be called a facial classification; the dissent's critique on this point is compelling. ${ }^{278}$ Yet to admit the facial neutrality of the initiative demanded an inquiry into electoral motive. The Court was reluctant to undertake this inquiry despite the trial court's imaginative efforts to develop a record. Second, the Court was understandably hesitant explicitly to an-

276. Although Justice Blackum never explicitly refers to Initiative $\mathbf{3 5 0}$ as a "racial classification," his comments suggest quite strongly that this is his conclusion. See id. (not "every attempt to address a racial issue gives rise to an impermissible racial classification," but when decisionmaking mechanism used to address racially conscious legislation is singled out for peculiar and disadvantageous treatment, governmental action plainly rests on distinctions based on race).

277. Id. at 460 \& n.1.

278. Id. at 494 (Powell, J., dissenting) (majority's argument that Initiative 350 created racial classification where identical action by school board would have created no such classification "is not an easy argument to answer because it seems to make no sense"); see also Sunstein, supra note 272, at 157-58 (Court was incorrect to characterize Initiative 350 as a conventional racial classification). Professor Sunstein believes, as I do, that notwithstanding the majority's erroneous premise, heightened scrutiny was warranted by suspicions that improper motivations were at work in Seallle. His reasons, however, are different. Id. at 158-59 (selective effort to prevent enactment of measures designed to desegregate "may well be not an effort to promote a public value, but the sort of unprincipled redistribution of wealth or opportunities" at which equal protection clause is aimed). 
nounce an exception to traditional doctrine when such an exception would have to be grounded on a distrust of electoral majorities. In the end, the majority opted for a patchwork, a combination of a relaxed standard for assessing purpose $\mathrm{e}^{\mathbf{2 7 \theta}}$ and a recognition that there exists a category of laws which, while not facially discriminatory, deserves a level of judicial scrutiny more exacting than ordinarily applied to facially neutral laws. ${ }^{\mathbf{2 8 0}}$

To assert that Seattle evinces a judicial willingness to look harder at substitutive plebiscites overstates my point-but not by much. If, as Justice Powell points out, the school district had repealed its own integration program, there seems little doubt that its action would have been held constitutional. ${ }^{281}$ What prompted the majority's action was not the simple repeal but the manner by which it was achieved. Would the issue posed have been altered had the school district's pupil reassignment authority been eliminated by the Washington legislature instead of by voter initiative?282

279. Although it would be a gross overstatement to say that the majority rests its affirmance on a finding of illicit motivation, the Court's expansive use of the concept of "racial purpose" seems a far cry from its miserly approach in Mobile v. Bolden, 446 U.S. 55 (1980). Two days after Seattle was decided, however, the Court seemed to loosen the Mobile criteria. See Rogers v. Lodge, 458 U.S. 613 (1982).

280. Sep Sunstein, supra note 272, at 150 (lesson of Hunter line of cases is that category of classifications exist "that qualify neither as facially neutral nor as facially discriminatory and that, while not as suspicious as the latter, ought not to receive the deference due to the former").

281. 458 U.S. at 494 (Powell, J. dissenting) ("It is not questioned that the District itself . . . could have changed its mind and canceled its integration program without violating the Federal Constitution."); ske also Crawford v. Board of Educ., 458 U.S. 527, 539 (1982) ("[T]he simple repeal or modification of desegregation or antidiscrimination laws, without more, never has been viewed as embodying a presumptively invalid racial classification.").

282. In Lee v. Nyquist, 318 F. Supp. 710 (W.D.N.Y. 1970), summarily affd, 402 U.S. 935 (1971), the New York legislature circumvented the state Commissioner of Education's effort to implement a school integration plan through Buffalo's appointed school board. The legislature enacted a statute barring state education officials and appointed local school boards from assigning students to attend any school "on account of race . . . or for purpose of achieving [racial] equality in attendance ... at any school." 318 F. Supp. at 712 . On the authority of Hunter v. Erickson, 393 U.S. 385 (1969), a three-judge Federal court invalidated the statute, concluding that the legislation drew an impermissible line "between the treatment of problems involving racial matters and that afforded ather problems in the same area." Id. at 718 (footnote omitted). The Supreme Court affirmed without oral argument or opinion.

Justice Blackmun's opinion for the majority in Seattle invoked the summary affirmance in Lee, concluding: "We see no relevant distinction between this case and Lee; indeed it is difficult to imagine a more precise parallel." 458 U.S. at 482 . Lee was no doubt correctly decided in view of the explicit racial line drawn by the New York legislature, but Justice Blackmun's equation of the two cases is not well thought out. To say that a representative body's reversal of the decision of appointed officials $\left(L e^{\prime}\right)$ is in no relevant way different from an unfiltered majoritarian veto of a decision arrived at by a deliberative, and very accountable, representative body (Seatlle) is to fail to appreciate the nature of a republican form of government. That legislatures may go astray is not denied. But this does not mean that their facially neutral actions deserve the same degree of judicial skepticism as electoral circumventions of the representative process.

It is not coincidental that Hunter $v$. Erickson, the principal case relied on by the Seattle majority, itself involved a voter bypass of the legislature. In Hunter, the Court struck down a substitutive plebiscite changing the city charter to require voter approval of open housing ordinances and declaring that existing ordinances "shall cease to be effective until approved by the electors." 393 U.S. at 387. As in Seatlle, the majority, having been thwarted by its representatives' sensitivity to minority interests, sought to circumvent the filtering process. Nor can it be overlooked that Hunter rose in the shadows of Reitman 7 . Mulkey, yet another substitutive plebiscite designed to silence the minority 
An interesting way to isolate the factors that triggered judicial suspicion in Seattle is to compare it with Crawford $v$. Board of Education. ${ }^{283}$ In many ways the cases look alike. The California Supreme Court had ordered pupil reassignment based on a finding of de facto discrimination under the California Constitution. In response, the state's electorate ratified Proposition 1, a constitutional amendment stripping state courts of the power to order busing except in cases of Fourteenth Amendment violations. On the very same day that Seattle struck down Initiative 350, the Justices upheld Proposition 1 by an eight to one vote. It is not uncommon for commentators to express disbelief that the cases were decided by the same Court, much less on the same day. ${ }^{284}$ I do not intend to try the reader's patience by reviewing or analyzing the creative efforts of scholars and judges to make some sense of these two opinions. I only wish to point out a distinction that seems to have thus far gone virtually unnoticed. In marked contrast to Initiative 350, Proposition 1 was a complementary plebiscite. The electorate was not alone in its assessment that the judiciary's reading of the California Constitution had gone too far beyond the Federal standard. Proposition 1 both received a popular mandate and passed through the legislative filters. It was approved in the State Senate by a vote of twenty-eight to six and the State Assembly by a similarly lopsided margin of sixty-two to seventeen. ${ }^{285}$ Here was not a case of the people bypassing the legislative checking structure. Proposition 1 represented an electoral-legislative consensus.

The fact that Proposition 1 reflected an augmented rather than truncated version of lawmaking does not mean that racially impermissible purposes did not drive its passage. But it does begin to explain why the Supreme Court was unwilling to look with added intensity for such illicit motivations, following instead a more traditional line than it used in Seattle. ${ }^{286}$ Admittedly, none of this is explicit in the two opinions. ${ }^{287}$ Perhaps

voice heard too loudly in representative councils. In Reitman, 387 U.S. 369 (1967), the justices invalidated a California constitutional initiative which superseded state fair housing legislation and withdrew legislative authority to regulate private discrimination in the housing market.

283. 458 U.S. 527 (1982).

284. See, e.g., Sunstein, supra note 272, at 155; see also L. TRIBE, supra note 28, at 1486-88; Choper, The Repeal of Remedies for De Facto School Desegregation, in J. CHOPER, Y. KAMISAR \& L. TRIBE, supra note 4, at 35-53 (1983); The Supreme Court, 1981 Term-Leading Cases, 96 HARv. L. Rev. 62, 120-30 (1982). In fact, five of the Court's members-Marshall, who dissented in Crauford, and Powell, Burger, Rehnquist and O'Connor, who dissented in Seatlle-viewed the cases as irreconcilable.

285. Crawford, 458 U.S. at 532 n.5.

286. In holding that Proposition 1 was "not motivated by a discriminatory purpose," the eightJustice majority in Crawford completely deferred to the conclusion of the California Court of Appeals. 458 U.S. at 545 . The Court prefaced its deferral by noting how the California court was "armed . . . with the knowledge of the facts and circumstances concerning the passage" of the Proposition. Id. at 543 (quoting from Reitman v. Mulkey, 387 U.S. 369, 378 (1967)). What made this statement so odd was that the California court had conducted no evidentiary hearing on the question of motive. See id. at 562 n.7 (Marshall, J., dissenting) ("How can any deference be given to the state court's 'knowledge of the facts'. . . when no such findings were ever made."). Despite the fact that challengers flooded the California court with newspaper clippings suggesting that the proposition was 
it is even fanciful to believe that any Justice would acknowledge the correctness of the interpretation presented here. However, a harder judicial look is what the Washington initiative called for and a harder judicial look is what the Justices gave it. In Crawford, on the other hand, where the checking structure had not been bypassed, the Court deferred to the political process. ${ }^{288}$ If that is not what was running through the Justices' minds, it is at least what this Article urges ought to have been.

New threats to minority rights have emerged in the latest batch of substitutive plebiscites. Recent initiatives in Arizona, California, and Colorado declare English the official language. Large portions of these measures are symbolic and offer little opportunity for courts to remedy the gratuitous insult they represent to the twenty million Americans whose native tongue is not English. ${ }^{289}$ It is likely, however, that these declarations will be invoked in efforts to terminate states' bilingual programs. Galifornia's constitutional initiative, for example, grants any resident standing to challenge any law that "diminishes or ignores the role of English as the common language of the State." ${ }^{\prime 280}$ Traditional equal protection doctrine may be ill-equipped to afford protection from these efforts. Attempts to demonstrate that the initiatives are motivated by animus against non-English speaking persons will encounter the proof difficulties identified earlier. Nor is it clear that language-based classifications, even if

specifically designed to maintain segregated schools, see Fischer, supra note 28, at 74 n.152, the court simply reasoned that legitimate purposes had been stated in the Proposition itself. Crawford v. Board of Educ., 113 Cal. App. 3d 633, 655, 170 Cal. Rptr. 495, 509 (1981). The lower court's ruling on motive turned not on a factual inquiry into the circumstances surrounding the passage of Proposition 1 , but on whether courts can or should look beyond these self-serving statements. The Supreme Court was better equipped for such a ruling than the California Court of Appeals. What was clear was that the justices had no interest in looking too deeply at what "really" happened, an approach in sharp contrast with the penetrating realism of Seattle.

Crauford manifests an inclination to replace realism with formalism in yet another way. The imaginative reworking of the conventional definition of racial classification at work in Seallle, see supra note 278 and accompanying text, was nowhere in evidence in Crawford. See Sunstein, supra note 272, at 155-56 ("In Seatlle, the Court read Hunter to suggest that race-specific classifications are to be treated like conventional racial classifications . . . In Crawford, the Court indicated that decisions that single out racial problems are not to be treated like racial classifications at all."). Nor was the single footnote reference to Seatlle in the Crawford opinion, 458 U.S. at 536 n.12, helpful in reconciling the widely divergent conceptions.

287. The majority opinion in Crawford does recite the legislative vote. See 458 U.S. at 532 n.5. On the other hand, when the Court concludes its opinion by stating a refusal to "impugn the motives of the State's electorate" in its approval of Proposition 1, id. at 545, it fails to take note of the fact that the legislature reached similar results by overwhelming margins.

288. I do not mean to suggest here that I think Crawford was correctly decided. My point is simply that the Court was correct in perceiving Seatlle as the more serious problem. In Part III.B I discuss my conception of the proper judicial role where complementary plebiscites are under review.

289. See generally K. KARST, supra note 223, at 98-100. An imaginative Federal district judge recently invalidated the Arizona measure on First Amendment grounds, concluding that it prohibited any state employee from using a language other than English in the performance of official duties. Thus read, it impeded the ability of state legislators to communicate with constitutents, created barriers to the judicial performance of marriage ceremonies, and impaired the First Amendment rights of all public employees to comment officially on matters of public concern. See Yniguez v. Mofford, No. CIV 88-1854 (D. Ariz. Feb. 6, 1990) (1990 U.S. Dist. LEXIS 1161).

290. CAL. Const. art. III, $\S 6(\mathrm{c})$. 
demonstrated, warrant enhanced scrutiny under current doctrine. ${ }^{201}$ The harder judicial look warranted by these xenophobic substitutive plebiscites may call for enhanced sensitivity to the quality of suspectness as well as a relaxed standard for assessing motivation. It is obviously unmanageable for courts to maintain different lists of suspect classifications depending on the nature of the lawmaker doing the classifying. On the other hand, there is more than a little illogic in testing for suspectness by examining "legislative response" to a minority's problems ${ }^{222}$ when the plebiscitary bypass is being traveled precisely because the legislature has proved too responsive.

Altering the manner in which discrimination is measured is just a portion of what I mean to convey by the concept of a hard judicial look. There are scores of other situations in which courts might take account of the ways in which the substitutive plebiscite operates differently from the legislative process. In the hope that it will leave the reader with some small sense of the breadth of possibilities, a few brief examples follow.

Rationality review under the equal protection clause entails enormous deference to the lawmakers' classification scheme. Courts have generally been willing to uphold any classification based upon facts that reasonably can be conceived to constitute a distinction. It has made little difference whether the conceivable facts actually exist, justify the classification, or were ever presented to the lawmakers. ${ }^{203}$ In part, this deferential approach is premised on a presumption that legislatures conduct hearings, that it is impossible for courts to review all that the legislature considered, and that legislatures are more competent factfinders than the courts. Courts sporadically move away from this deferential stance to a heightened scrutiny in response to factors they regard as suspect in some sense but are unwilling to label as such. ${ }^{294}$ The absence of structured factfinding in the substitutive plebiscite ${ }^{295}$ and the dangers of classification inherent in a process of naked aggregation suggest that the substitutive plebiscite may be one of those situations that warrants heightened ends-means review. ${ }^{296}$

Whether economic regulation by substitutive plebiscite also deserves a harder judicial look presents one of the more difficult questions under the

291. On language minorities and the equal protection clause, see generally Califa, Declaring English the Official Language: Prejudice Spoken Here, 24 Harv. C.R.-C.L. I. REv. 293 (1989), and Note, "Official English": Federal Limits on Efforts to Curtail Bilingual Services in the States, 100 HARv. L. Rev. 1345, 1352-61 (1987). See also Moran, Bilingual Education as a Status Conflict, 75 Calif, L. Rev. 321 (1987).

292. See City of Cleburne v. Cleburne Living Center, 473 U.S. 432, 443-45 (1985).

293. See L. TRIBE, supra note 28 , at 1443.

294. Id. at 1445 .

295. See supra text accompanying notes 143-144.

296. Cf. Linde, supra note 144, at 227-28 (voter initiatives prove that due process clause does not demand that lawmakers evaluate means-ends rationality of laws since the initiative process "flies in the face of the idea"). 
thesis I offer. Economic regulation generally receives only a passing judicial glance when enacted through ordinary legislative channels. Courts have virtually abdicated rationality review of these kinds of laws under the due process or equal protection clauses and, despite some recent anomalies, claims of contractual impairment and regulatory takings seldom encounter a sympathetic judiciary. The wisdom of this "hands-off" approach is beyond the scope of this Article. ${ }^{287}$ What is worthy of inquiry, however, is the extent to which this traditional judicial restraint, grounded in large part on deference to legislative judgment, is equally appropriate when applied to the more haphazard, less deliberative plebiscitary arena.

In November 1988, California voters, fed up with spiraling automobile insurance premiums and frustrated by (1) a legislature which seemed unwilling or unable to address the problem and (2) an insurance industry whose closed records made public scrutiny of profit margins impossible, were offered an opportunity to vent their anger in a financially lucrative manner. Proposition 103, an initiative spearheaded by Ralph Nader, proposed to reduce insurance rates immediately to a level "at least 20 percent less" than those in effect in November 1987. Rates were to be frozen at that level until November 1989, unless the state's insurance commissioner granted exemptions to individual insurers found to be "substantially threatened with insolvency."28s

The complexity of Proposition $103^{289}$ was just a small part of the considerable difficulty voters faced in sorting out their vote. Three "alternative" insurance initiatives, some sponsored by the insurance industry itself, appeared on the November ballot. ${ }^{300}$ Voters unable to grasp the finer distinctions between Proposition 103 and the competing Propositions 100, 101, and 104 could hardly be faulted. The text and analysis of the insurance reform proposals filled forty-two pages of microscopic print in the ballot pamphlets mailed to voters. Nor was there a shortage of campaign advertising designed to "elucidate" the issues. The staggering sum of $\$ 100$ million was spent by the competing factions-most of it by the insurance industry-in the battle over insurance reform. ${ }^{301}$

If among the nine million voters there were some who purported to understand the pros and cons of the various measures, I was not one of them. For reasons about which one can only speculate-my own guess is that many voters were guided by a trust in Ralph Nader-Proposition

297. I have considered its wisdom in Eule, Pracess Protection and the Economic Rights Provisions of the Constitution, George Mason L. Rev., Winter 1988, at 73.

298. See California Ballot Pamphlet for the Not. 8, 1988, General Election, at 99.

299. In addition to rate roll-backs, Proposition 103 contained a wide assortment of collateral regulations covering subjects as diverse as the authorization of insurance activities by banks, the creation of a consumer advocacy corporation, provisions for an elected Insurance Commissioner, and abrogation of the industry's antitrust immunity. Id. at 99, 140-44.

300. A fourth "alternative" to Proposition 103 proposed to reduce insurance rates indirectly by limiting attorney fees in tort actions.

301. See Wolinsky, supra note 247 , at 3 , col. 1 . 
103 alone passed, and only by the barest of margins. ${ }^{302}$ If this vote did not constitute legislation by lottery, it represented at least lawmaking that was more visceral than considered.

Standing to lose an estimated $\$ 4$ billion as a consequence of Proposition 103 in the first year alone, ${ }^{303}$ the insurance industry carried the battle lost at the ballot box to the California Supreme Court. The challengers' attack focused on the rate roll-back and subsequent adjustment procedures, contending that the figures used were arbitrary and confiscatory. The justices unanimously upheld the facial validity of the twenty percent roll-back but struck down the standards for individual adjustments. The United States Constitution, concluded the court, demands that insurance companies get a "fair and reasonable" rate of return. The ballot measure's assurance only of protection from insolvency fell short of that guarantee. ${ }^{304}$ Challengers sought to parlay this partial victory into a total one by contending that Proposition's 103 severability clause should be ignored and the entire measure invalidated because of the taint of the impermissible adjustment procedures. The court rejected the argument, asserting that the voters would likely have enacted the initiative "had they foreseen the invalidity of the insolvency standard." 305

It is hard to feel particularly sorry for the insurance industry. Having effectively paralyzed every legislative effort to resolve the statewide insurance crisis, it mounted a well-financed and well-organized battle to stymie the electorate as well. True, the insurance companies ultimately lost, but not because their voice went unheard. The case for a filtering check here does not appear a compelling one.

But the problem is more complex. It is not immediately evident what warrants judicial deference to electoral policy judgments that the electorate never actually made. On one level Proposition 103 represents a clear expression of citizen sentiment. It effectively conveyed to the legislature the level of voter concern and dissatisfaction on an issue marked by legis-

302. Proposition 103 received $4,580,818$ or $51.1 \%$ of the votes cast, while $4,376,916$ or $48.9 \%$ of the electorate voted against the measure. See L.A. Times, Nov. 10, 1988, at 26, col. 3.

303. The estimate comes from John Crosby, the insurance industry's campaign coordinator. See Wolinsky, supra note 247 , at 23 , col. 2.

304. See Calfarm Ins. Co. v. Deukmejian, 48 Cal. 3d 805, 816-21, 771 P.2d 1247, 1252-56 (1989). The court reached the same result under the California Constitution. $48 \mathrm{Cal} .3 \mathrm{~d}$ at 821,771 P.2d at 1256. Once the insolvency provisions were struck, the only insurers who remained subject to the $20 \%$ roll-back were those whose rates provided a reasonable rate of return even after application of the rate reduction. Each of the state's top 15 sellers of insurance subsequently contended that the roll-back would leave them without a reasonable rate of return. Their applications for exemptions are now pending before California's insurance commissioner. See 443 Insurers Seek Rollback Exemptions, L.A. Times, June 27, 1989, at 3, col. 2.

305. Calfarm, 48 Cal. $3 \mathrm{~d}$ at 822,771 P.2d at 1256. Although this conclusion is undoubtedly sound, courts ought to give little credence to the presence of a severability clause in a voter initiative. It is safe to say that scarcely any voter was aware that Proposition 103 contained a severability clause. Its inclusion offers little evidence of anything save the drafter's intent. Cf. Brockett v. Spokane Arcades, Inc., 454 U.S. 1022, 1024 (1981) (Burger, G.J., dissenting) (criticizing lower court for ignoring explicit severability clause in voter initiative). 
lative cowardice. The particulars of the enacted reforms, however, represent little more than the speculative musings of the drafters ${ }^{306}$ who were then able to harness a frustrated, angry, and financially drained electorate into passage, based largely on Ralph Nader's endorsement and the promise of lower premiums. To suggest that the voters approved, let alone understood, the many facets of Proposition 103 is pure mythology.

Having said all this, it is not obvious to me what the judicial response ought to be. Courts do not always correct irrationality in the legislative process. In United States Railroad Retirement Board V. Fritz, ${ }^{307}$ the Court turned a deaf ear to the claim that Congress had been unaware-or even misinformed-of the bizarre statutory classification it had created governing eligibility requirements for "windfall" retirement benefits. The opinion, authored by Justice Rehnquist, argued that if the test of legislative awareness "were applied literally to every member of any legislature that ever voted on a law, there would be few laws which would survive it." Where the language of the law is clear, Rehnquist concluded, we will assume that the legislative body intended what it enacted. ${ }^{308}$ When the Court on occasion departs from the deferential stance to socio-economic regulation manifested in Fritz, it is usually because some powerless group has been disadvantaged. ${ }^{300}$

Now, I have no wish to defend Fritz's refusal to consider reality. It appears to me that if Congress had no idea that it was depriving certain persons of retirement benefits, there is little sense in deferring to its judgment. But if Fritz represents the proper approach, the question must be whether such an approach is equally appropriate in a process considerably more susceptible to uninformed decision-making. Two factors seem to argue for extending Fritz to plebiscites. First, how can a court accurately gauge what the voters knew? Although I am prepared to testify as to the enormous voter confusion-including my own-regarding the four insurance reform initiatives, do we really think that courts can monitor confusion on a systematic basis? Second, the costs of such an approach are high.

306. There is not the slightest hint, for example, of what relation the $20 \%$ figure has to industry profits or why November 1987, was chosen as the base for the roll-back. Admittedly, the drafters cannot be blamed for having to pick numbers out of a hat. The insurance industry's refusal to open its financial records voluntarily, and the absence of laws requiring such public disclosure, left them little choice. But ratemaking by guesswork deserves little judicial deference.

307. 449 U.S. 166 (1980).

308. Id. at 179. But sep id. at 197-98 (Brennan, J., dissenting) (that courts ought not secondguess wisdom of legislative efforts does not mean that courts must defer to statutory results that legislature did not intend).

309. Ser, e.g., City of Cleburne v. Cleburne Living Center, Inc., 473 U.S. 432 (1985) (invalidating zoning ordinance requiring special permit for home for mentally retarded on grounds of irrationality); Plyler v. Doe, 457 U.S. 202 (1982) (invalidating law denying free public education to children of undocumented aliens on grounds of irrationality). An argument can be made that the dispossessed retirees in Fritz were indeed a powerless group whose rights were traded away by representatives of railroad management and labor to enhance benefits for currently employed railroad workers. See 449 U.S. at 191 (Brennan, J., dissenting) (citing District Court Findings of Fact). 
As I shall discuss shortly, setting aside electoral preferences is always risky judicial business. It is one thing to expend scarce judicial good will in order to protect the powerless whose voices are stifled in the unfiltered setting of the substitutive plebiscite. It is quite another to do so on behalf of a group that spent in excess of $\$ 60$ million conveying its message to the voters. ${ }^{310} \mathrm{~A}$ harder judicial look in this type of setting thwarts the highest aspirations of the initiative process-to overcome the impediments to public interest legislation posed by financially powerful lobby groups.

It is difficult to assess whether the California Supreme Court altered its approach because the law under review originated with the voters rather than the legislature. Nothing in the language of the opinion itself suggests a departure from the ordinary standard of review. Yet in an effective, if somewhat subtle manner, the California Supreme Court was sensitive to the dilemma described above. It seemed to sense that the twenty percent roll-back figure came out of nowhere, that it bore no relationship to any factual findings regarding industry profits. Its across-the-board applicability to all insurers, regardless of a company's particular financial circumstances and the type of policy involved, was merely a crude effort to punish the insurers. The court also sensed, however, that consumers were angry, that Proposition 103 was a venting of that anger, and that judicial invalidation might redirect the focus of their ire. Its solution was to rewrite rather than void the proposition. The twenty percent roll-back would theoretically remain in place but the reality was that the insurance commissioner-soon to be an elected official-would individually set each insurer's rate at a "fair and reasonable level," a standard which nowhere appears in the ballot measure itself. ${ }^{311}$ The voice of the plebiscite would be heard at a general level but the particulars-heavily dependent on factual determinations-would be administratively set. Small wonder that both sides claimed victory in the wake of the California Supreme Court's decision.

I do not perceive the concept of a hard judicial look to be a rigid one. Unlike "strict scrutiny"-a standard which on paper at least can be reduced to precise formulation-it is not intended to take on a unitary form.

310. If the electorate was indeed confused about Proposition 103, it was largely as a result of the insurance industry's own efforts.

311. The initiative contained a section, $\S 1861.05$, prohibiting the insurance commissioner from permitting any rate "which is excessive, inadequate, [or] unfairly discriminatory." California Ballot Painphlet, supra note 298, at 99 (emphasis added). The section was qualified by limiting rate adjustments prior to November 1989 to insurers substantially threatened with insolvency. The court reasoned that once it struck the insolvency qualification, the commissioner was required to permit insurers "fair and reasonable" rates of return. It read "inadequate" in $\$ 1861.05$ to mean "confiscatory" and "confiscatory" to mean a rate that was not "fair and reasonable." 48 Cal. $3 \mathrm{~d}$ at $822-23,771$ P.2d at $1256-57$. No insurer would thus be subject to the $20 \%$ roll-back unless it either acquiesced in such a reduction or was unable to prove to the commissioner that a higher rate was needed to ensure a fair rate of return. $48 \mathrm{Cal}$. 3d at 825,771 P.2d at $1258-59$. By June of 1989 it was clear that acquiescence was not something the insurers were considering. See supra note 304. 
What I have in mind is more a general notion that courts should be willing to examine the realities of substitutive plebiscites ${ }^{312}$ - that the unspoken assumptions about the legislative process that so often induce judicial restraint deserve less play in a setting where they are more fanciful. Sometimes a hard judicial look will take the form-as it does in Seattle-of a candid "We know what's going on here and we won't allow any of it." In other situations-like Proposition 103 and similar corporate regulation-recognition that the burden of plebiscitary action falls on political actors able to defend their interests in the popular arena, combined with a need to conserve limited judicial capital, will appropriately lead to a more modest form of review. ${ }^{313}$

\section{B. Judicial Review of Complementary Plebiscites}

Complementary plebiscites are birds of a different feather. Because they originate in the legislature, they must pass through its elaborate filtering system. The drafting reflects a more experienced hand. Committees are consulted. Hearings usually precede passage. Most importantly, the end result generally reflects compromise. Opposition not anticipated by the drafters may be corrected by amendment. The measures sent on to the voters for ratification tend to be less divisive than a ballot effort initiated by a special interest group without the benefit of a legislative hand to guide it toward the political center. It is hardly surprising that voters approve complementary plebiscites at almost twice the rate that they pass substitutive ones. ${ }^{314}$

At first glance, the enhanced judicial role advanced in the preceding pages would appear to have no place in the review of complementary plebiscites. This initial intuition may be only half right. A more considered analysis requires that we divide complementary plebiscites into two

312. This realism might reasonably be extended to review of legislation seeking to reform the plebiscitary process. Many state legislatures are engaged in admirable efforts to limit the impact of money on the qualification of initiatives and the campaigns that follow. Thus far, the Supreme Court has stymied those efforts based on an idealized vision of the process which refuses to acknowledge the corrupting influence of wealthy and powerful corporate interests on citizen lawmaking. Meyer v Grant, 108 S. Ct. 1886 (1988) (invalidating Colorado statute prohibiting use of paid circulators for qualifying initiative proposals); First Nat'l Bank of Boston v. Bellotti, 435 U.S. 765 (1978) (voiding Massachusetts statute forbidding use of corporate funds to influence referendum votes on issues having no connection with corporation's business). For a penetrating attack on Meyer v. Grant, see Stern \& Lowenstein, Paid Initiatize Circulators and the First Amendment, 17 Hastings Const. L.Q. (forthcoming 1990); see also Lowenstein, supra note 27, at 583-602 (recommending adoption of contribution limits in ballot measure campaigns).

313. A full picture of a hard judicial look might embrace different rules of statutory construction as well as different standards of constitutional interpretation. Courts reviewing substitutive plebiscites might exhibit a greater willingness to find Federal preemption, or they might opt for narrow rather than liberal construction of ambiguous language. $C f$. Macey, supra note 121, at 226 (constitutional requirement that judiciary serve as check on statutory excesses can be fulfilled through statutory interpretation). But see Note, supra note 264, at 157 (courts should not use statutory interpretation to muffe unfiltered voice of people).

314. Ser supra note 191. 
subgroups depending on the voter outcome-the "positive" form in which the voters endorse the legislative choice and the "negative" one in which they obstruct it.

When voters ratify the legislative choice, judicial deference is well deserved. The statutory product reflects extraordinary consensus. A filtered legislative result has received popular endorsement. Supporters of participatory democracy and representative government can join hands to celebrate the result. Although an argument can be made that electorallegislative consensus deserves more than the usual presumption of constitutionality which attaches to ordinary legislation, two factors argue against relaxed scrutiny. First, the process of "referred" legislation often excludes the executive branch. The signature of the governor may not be required for laws which must be submitted for electoral approval. ${ }^{315}$ More important, the legislature may not take its responsibilities as seriously when it is only a waystation on the route to a plebiscite. The referendum process may promote legislative laziness or cowardice. Associate Justice Michael Gillette of the Oregon Supreme Court recently observed the increasing tendency of his state's legislature to use referenda as a way to pass the buck on difficult public policy decisions. ${ }^{316}$ It will be difficult of course for a judicial body to gauge when such shirking has occurred, but the danger that a legislature will go about its task halfheartedly when it knows the electorate will be making the final decision counsels against affording this augmented process more than the ordinary judicial deference. ${ }^{317}$

When voters veto the legislative choice there is no electoral-legislative consensus. The participatory and representative processes arrive at competing conclusions and the electorate prevails. In the sense that it bypasses the legislative result, the "negative" complementary plebiscite operates very much like the substitutive plebiscite. There is, however, a critical difference. The substitutive plebiscite enables popular majorities to pass legislation that minorities have managed to prevent in the legislature. In

315. See, e.g., ARIz. ConST. art. IV, pt. 1, § 1(6). Sometimes, as is typical in the constitutional amendment process, the absence of an executive check is offset by the requirement of a legislative super-majority. See, e.g., CAL. ConST. art. XVIII, $\S 1$.

The impact of circumventing the executive check was graphically illustrated in a November 1988 Michigan referendum. Opponents of abortion had repeatedly won legislative victories cutting back on Medicaid abortion funding only to see Governor William Milliken and his successor James Blanchard veto the bans. By virtue of a legislative victory confirmed by the 1988 complementary plebiscite, however, the anti-abortion forces were able to bypass the governor and enact the ban. See INITIATIVE AND REFERENDUM REPORT, supra note 50, at 1-2.

316. See Gillette, The Legislative Function: Initiatize and Referendum, 67 OR. L. REv. 55, 63 (1988); see also S. HAYS, supra note 38, at 229 n.38 (referendum popularized by legislative bodies seeking to resolve impasses or to pass responsibility for decision to public).

317. This scenario is applicable only to the "compulsory" or "voluntary" forms of referenda. Sep supra text accompanying notes 33-37. In a "popular" referendum the voters only petition for electoral input after the legislature has already passed the legislation. Thus the legislature will probably be unaware that its voice is not the last one at the time it goes about its legislative duties. 
contrast, "negative" complementary plebiscites result not in new law but in the preservation of the status quo. ${ }^{318}$

Nonetheless, these "negative" complementary plebiscites pose a distinctive threat of majority tyranny. Complementary plebiscites enable popular majorities to prevent legislation that minorities have managed to convince legislative majorities to enact. Sometimes legislative sensitivity to minority interests, as well as debts incurred by the process of logrolling and compromise, result in minorities' being able to assert their legislative power in a positive rather than negative manner. Where the minority's legislative victory takes the form of passing rather than preventing legislation, complementary plebiscites-which make lawmaking more difficult-may deserve enhanced judicial attention.

Why should a constitutional vision of checks and filters be offended by the operation of an additional check? The protection the Constitution offers minorities is chiefly one against legislative action, not inaction. ${ }^{319}$ As Jesse Choper correctly notes, the great bulk of the antimajoritarian elements found in our system are negative ones. "They work to prevent the translation of popular wishes into governing rules rather than to produce laws that are contrary to majority sentiment." ${ }^{320}$ Checks and filters might screen out "good laws," but Federalists like Alexander Hamilton deemed this price worth paying. "[E]very institution calculated to restrain the excess of law-making, and to keep things in the same state in which they may happen to be at any given period," he argued, is "much more likely to do good than harm." The injury done by defeating a few good laws "will be amply compensated by the advantage of preventing a number of bad ones." 321

318. On rare occasions, a substitutive plebiscite may attempt to repeal existing legislation rather than enact new law. Ser, e.g., Reitman v. Mulkey, 387 U.S. 369 (1967) (constitutional initiative used to supersede legislatively promulgated fair housing laws). Yet, because the substitutive plebiscite repeals existing law, while the "negative" complementary plebiscite prevents a law from ever taking effect, only the former changes the status quo.

319. This is simply a corollary of the principle that the Constitution limits government rather than imposes affirmative obligations on it. See DeShaney v. Winnebago County Dep't of Social Servs. 109 S. Ct. 998 (1989). But see L. TRIBE, supra note 28, at 1305 ("freedom cannot be defined wholly in the negative language of containing the wayward state;" meaningful freedom requires imposition of affirmative duties on government as well as demanding that it refrain from certain controls of conduct); Amar, Republicanisin and Minimal Entitlements: Of Safety Valves and the Safety Net, George MASON L. REv., Winter 1988, at 47, 49 (Thirteenth Amendment envisions government provision of minimum property entitlement to all citizens); Michelman, The Supreme Court, 1968 Term-Forruord: On Protecting the Poor Through the Fourteenth Amendment, 83 Harv. L. Rev. 7 (1969) (government has affirmative obligation to provide at least minimum level of services necessary to avoid severe deprivation).

320. See J. Choper, supra note 122, at 26 (emphasis in original). But see Amar, supra note 2, at 1084.

321. Sep The Federalist No. 73, at 496 (A. Hamilton). But see id. No. 22, at 141, where Hamilton appears to take a 180 degree turn. Opposing the imposition of super-majority requirements, he argues:

Where the concurrence of a large number is required by the constitution to the doing of any national act, we are apt to rest satisfied that all is safe, because nothing improper will be likely to be done; but we forget how much good can be prevented, and how much ill may be pro- 
The picture of complementary plebiscite as additional check is a superficially appealing one. Viewed this way it looks a lot like bicameralism or executive veto or judicial review. Of course the complementary plebiscite is a filter that the Federal Constitution did not install, but surely the states are not barred from making it more difficult for government to act. ${ }^{322}$ The problem with this portrayal is that it assumes a filtering system that applies equally to all lawmaking. But that is not the reality of complementary plebiscites, which instead provide selective augmentation of the ordinary legislative process.

Not all complementary plebiscites are suspect merely because of their selectivity. It is entirely legitimate for states to require complementary plebiscites for constitutional amendment. Preventing momentary majorities-whether legislative or electoral-from altering the state's constitutive document appropriately calls for a procedure incorporating extra checks. The difficulty arises when subjects that disproportionately affect unpopular minorities-like blacks, latinos, aliens, or the poor-are singled out for an augmented checking system.

I have argued in this Article that substitutive plebiscites demand additional judicial attention because they bypass the legislative filtering system designed to protect minority interests. Complementary plebiscites pose a danger of a different sort. We frequently hear the praises of allowing the electorate to pass on the action of their representatives in a more focused manner than that afforded by periodic retention elections. But when the road to legislation is lengthened only sporadically, we must be extremely wary about the process for picking those moments. For while nothing may be wrong with allowing the voters to reject their agents' decisions, the selective use of the voter veto is fraught with danger to unpopular minorities.

When a state constitution or a city charter mandates that specific categories of legislation receive the dual approval of legislators and voters, courts should scrutinize this requirement itself for impermissible antiminority bias. Thus it will not be necessary for judges to pass on the individual exercise of the plebiscitary veto-and indeed it may not be possible. The Court has taken precisely this approach in Hunter $v$. Erickson, ${ }^{323}$ James v. Valtierra, ${ }^{324}$ and City of Eastlake v. Forest City Enter-

duced, by the power of hindering the doing what may be necessary, and of keeping affairs in the same unfavorable posture in which they may happen to stand at particular periods.

322. See, e.g., Gordon v. Lance, 403 U.S. 1 (1971) (upholding requirement that political subdivisions of West Virginia may not incur bonded indebtedness or increase tax rates without approval of $60 \%$ of voters in referendum).

323. 393 U.S. 385 (1969) (striking down city charter provision requiring complementary plebiscites for any open housing ordinances). Although the voter action adopting the city charter also repealed an existing open housing ordinance, the Court took pains to point out that it was the selective imposition of the plebiscitary procedure and not the "mere repeal" that violated the fourteenth amendment. $I d$. at 390 n.5.

324. 402 U.S. 137 (1971) (upholding state constitutional provision requiring complementary pleb- 
prises. ${ }^{325}$ In each of these cases, a state constitution (in the case of James) or a city charter provision (in the case of Hunter and Eastlake) required complementary plebiscites for specified governmental actions. The Court's attention was correctly directed not at a particular electoral veto but at the constitutionality of the structural provision requiring submission of the issue to the voters. In Part III.A, I advocated an enhanced substantive review of the individual product of substitutive plebiscites. When it comes to complementary plebiscites my claim is rather that courts must look harder at the fairness of the selective use of the process. ${ }^{326}$

The two approaches come together in an ironic manner. The selective imposition of complementary plebiscites, it turns out, is ordinarily achieved by voter initiatives. It is seldom the legislature that chooses to implement electoral filters. It is instead the voters who, bypassing their representatives, opt to augment the legislative process. In Hunter, in James, and in Eastlake, the constitutional amendments imposing the referendum requirements all resulted from substitutive plebiscites. Thus the plebiscitary tiers were doubly suspect. They represented a selectively imposed additional burden on lawmaking and they were accomplished by legislative bypass. The Supreme Court decisions paid some-although too little-attention to the selectivity problem ${ }^{327}$ They ignored or overlooked the unfiltered, electoral origins of the referendum requirements. ${ }^{328}$

iscites for low-rent public housing projects). Even though proposals for low-rent housing had been defeated by referendum, $i d$. at 139 , the case involved only a challenge to the constitutional provision mandating such an electoral submission.

325. 426 U.S. 668 (1976) (upholding city charter provision requiring complementary plebiscites for City Council proposed changes in land use). Once again, the Court's opinion focused on the structural provision and not on the voters' defeat of the specific proposed zoning change. Id. at $671-72$.

326. In most cases this review would take place under the equal protection clause. $C f$. Bell, supra note 4, at 28 (precedents protecting voting rights and integrity of electoral system can be applied against efforts to subvert gains made by minorities through participation in representative government); Seeley, The Public Referendum and Minorily Group Legislation: Postscript to Reitman v. Mulkey, 55 CoRnell. L. Rev. 881, 909 (1970) ("A system that subjects pro-minority group legislation already passed by representative government to [electoral] approval . . . [is] an obvious denial of a republican form of government."); see also Sager, supra note 144, at 1418 (use of plebiscite cannot be justified under due process clause where substantial constitutional values are placed in jeopardy and substantive review of voter enactment is largely unavailable).

327. In Hunter the Court took appropriate note of the selectivity problem. Even though Akron might have proceeded by complementary plebiscite on "all" its municipal legislation, having chosen to do something less, it "may no more disadvantage any particular group by making it more difficult to enact legislation in its behalf than it may dilute any person's vote." 393 U.S. at 392-93. Two years later the Court was in full retreat. A lawmaking procedure that "disadvantages" a particular group, said five justices in James, does not always deny equal protection. Such a holding, they warned, would prohibit a state from requiring referenda on any subject "unless referendums were required on all, because they would always disadvantage some group." 402 U.S. at 142. The Court's rejection of a per se rule of invalidity for any selective imposition of the complementary plebiscite was no doubt sound, but $i t$ is hard to condone its refusal meaningfully to review the justifications for singling out low-rent housing proposals for electoral veto. As Justice Marshall correctly notes in dissent, the Court subjected the state constitutional provision mandating complementary plebiscites "to no scrutiny whatsoever," treating it as if it were a technical economic classification. Id. at 145.

328. Indeed the Court often fails even to mention the specific method by which the requirements of complementary plebiscites were adopted. In Janes, for example, the Court notes simply that the 
A second form of "negative" complementary plebiscite, the "spot referendum," is discretionary rather than mandatory. In fourteen states, for example, a legislature may "voluntarily refer" a particular measure to the voters for passage. ${ }^{328}$ Substantial practical impediments block judicial review of either the legislative referral or the electoral veto. There is simply no law to pass on. Because legislative passage in this setting is contingent upon electoral acceptance, any claim that electoral veto repeals the legislative choice seems frivolous. Nor would the contention that these sorts of referrals constitute an impermissible delegation of legislative power be expected to meet with any success. ${ }^{\mathbf{3} 0}$

A theoretically more serious "spot referendum" from the vantage point of minorities is the so-called "popular" or "petition referendum." This device, available in twenty-four states, ${ }^{331}$ permits voters to force the legislature to refer an already enacted measure to the voters before it can go into effect. In several ways the popular referendum has the potential to be the most dangerous of direct democracy devices. Like the mandatory referendum, it affords an opportunity for inflamed majorities to take away gains that minority groups have struggled to achieve through the representative system. Because popular referenda will occur on an ad hoc rather than a structured basis, however, they may elude the type of judicial oversight evidenced by Hunter $v$. Erickson. ${ }^{332}$ Indeed, a court willing to review these electoral vetoes would have to rely on a thesis never accepted by a Supreme Court decision-that a "mere repeal" of a single piece of legislation unaccompanied by a broader restructuring of the political decision-making process can itself violate the Constitution. ${ }^{333}$ For the

California voters "adopted" the low-rent housing referendum procedure as a constitutional provision. Id. at 139. The California Constitution may be amended, however, either by voter initiative or by the joint action of the legislature and the voters. It is only by going back to the California voting pamphlet for 1950 that one learns that the legislature played no role in the promulgation of the structural provision under review. See Proposed Amendments to Constitution, General Election, November 7 , 1950, at 9 (Initiative Constitutional Amendment No. 10).

329. See supra note 36 and accompanying text.

330. See, e.g., City of Eastlake v. Forest Gity Enters., 426 U.S. 668, 675 (1976) (delegation doctrine is "inapplicable where . . . we deal with a power reserved by the people to themselves"); $c f$. Gillette, supra note 316, at 63-64 (urging that new Oregon Constitution include provisions to ensure that legislature does not use referenda "as a way in which . . . [to] shirk[] its responsibilities").

331. See supra note 37.

332. 393 U.S. at 394 (Harlan, J., concurring) (suggesting that if Akron voters petitioned for referendum and vetoed fair housing legislation instead of amending city charter to subject fair housing to automatic referendum, equal protection clause would not have been violated).

333. On a number of occasions the Court has stressed that a "mere repeal" of race-related legislation does not violate the equal protection clause. See, e.g., Hunter v. Erickson, 393 U.S. at 390 n.5; Reitman v. Mulkey, 387 U.S. 369, 376 (1967). When an entity other than that which passed the law in the first place is responsible for the repeal, the Court may view the constitutional challenge more sympathetically. See Crawford v. Board of Educ., 458 U.S. 527, 557 (1982) (Marshall, J., dissenting). But it is doubtful that a veto of a statute that never took effect can even be called a "repeal." Whatever the constitutional vulnerability of "mere repeals," the failure to enact legislation in the first place is ordinarily beyond substantive judicial review. Cf. Spallone v. United States, $110 \mathrm{~S}$. Ct. 625 (1990) (Federal judge abused discretion by imposing contempt sanctions against city council members for failure to adopt affordable housing ordinance in compliance with consent decree provisions). 
present, however, the threat of popular referenda is purely speculative. Because the time period for gathering the requisite signatures tends to be short-typically no more than ninety days after the adjournment of the legislative session that produced the law ${ }^{334}$ - the device has seldom been used. ${ }^{335}$

\section{Are State Courts Up to the Task?}

Although it is under the Federal Constitution, not those of the states, that enhanced judicial review of direct democracy is warranted, ${ }^{\mathbf{3 3 6}}$ the question remains which judicial system is best suited for this role. State and Federal courts share responsibility for the enforcement of Federal constitutional rights. Much has been written about the relative competence and enthusiasm of state courts in the performance of this duty. ${ }^{337}$ While I have no desire to take up the general question of parity here, judicial scrutiny of ballot measures provides a unique setting in which to contemplate the implications of state judicial elections. The sitting judges of the highest courts of all but two of the states that permit substitutive plebiscites are ultimately held directly accountable to the voters for their decisions. ${ }^{338}$ In approximately half of these states the judges serve a limited term-generally either six or eight years-and must thereafter run for reelection. ${ }^{339}$ In the remaining half, the electorate is periodically asked to vote on whether the judge should be "retained" in office. ${ }^{340}$ The fre-

334. The time frames for the various states are set forth in D. MAGLEBY, supra note 16, at 38-39 (Table 3.1).

335. According to Thomas Cronin, there was one popular referendum on the ballot in 1982, none in 1984 and four in 1986. See T. CRONIN, supra note 16, at 197 (Table 8.1); cf. P. MCGuigaN, supre note 15, at 28 (quoting somewhat larger numbers). There is at least some evidence of increased use of the popular referendum. In 1989, communities in California, Ohio, and Washington used such devices to void legislative gains achieved by gay and lesbian lobbying efforts, see 11 Family, Law \& Democracy Report, No. 12, at 9-10, 18 (Dec. 1989), and the people of North Dakota overturned no fewer than seven previously enacted statutory measures on a wide array of subject matters. See FAMILY, LAW \& DEMOCRACY REPORT, Jan. 1990, at 9-10.

336. Sep supra Part II.D.2.

337. The competing claims are ably reviewed in Chemerinsky, Parity Reconsidered: Defining a Role for the Federal Judiciary, 36 UCLA L. REv. 233 (1988). See also Bator, The State Courts and Federal Constitutional Litigation, 22 WM. \& MARY L. REv. 605 (1981); Neuborne, The Myth of Parily, 90 Harv. L. Rev. 1105 (1977).

338. Of the states with substitutive plebiscites, only Maine and Massachusetts shield the judges of their highest court from direct ballot review. In Maine there is an indirect accountability. Every seven years the members of the Maine Supreme Judicial Court must be reappointed by the governor and confirmed by a legislative commission. ME. Const. art. V, pt. $1, \S 8$; art. VI, $\S 4$. In contrast, the justices of the Massachusetts Supreme Judicial Court serve for life. MAss. Const. art. 82. As Lawrence Sager has noted, however, the ease with which a state constitution can be amended partially undermines the security of such grants of life tenure. See Sager, The Supreme Court 1980 Term-Forru'ord: Constitutional Limitations on Congress' Authority to Regulate the Jurisdiction of the Federal Courts, 95 HaRv. L. Rev. 17, 63 n.149 (1981). But see MASs. Const. arts. of amend. $152 \& 168$ (tenure of judges may not be subject of voter initiative or popular referendum).

339. These states (with the term of office in parenthesis) include Arkansas (8), Idaho (6), Michigan (8), Montana (8), Nevada (6), North Dakota (10), Ohio (6), Oregon (6), Utah (initial 3 years; then 10), and Washington (6). See infra Appendix B.

340. The substitutive plebiscite states that conduct so-called "retention" elections include Alaska, 
quency of retention elections varies greatly but averages about once every eight years. ${ }^{341}$ Because the judges in these "retention" states are ordinarily appointed rather than elected, the initial retention vote is usually set at a shorter time interval than subsequent ones. Thus, for example, the justices of the Colorado Supreme Court must submit for their first vote of confidence two years after their initial appointment to the bench, but thereafter they only receive electoral scrutiny every ten years. ${ }^{342}$

The electoral accountability of the state judiciary leaves little hope that state courts will have either the ability or the desire to take a leading role in filtering plebiscitary results. When Federal constitutional rights are at risk, the judicial role must be played by an independent judiciary. And the independence demanded must insulate the courts from the people as well as from the legislature..$^{343}$

The Constitution does not, of course, demand that a state afford life tenure to its judiciary. Nor does it demand that periodic renewal of a judge's tenure be handled by merit panel rather than by popular vote. The Constitution does, however, require that the rights it confers upon every member of the citizenry be enforced by an independent judiciary. As Chief Justice Rehnquist notes: "The independence of [the judiciary] . . . is every bit as important in securing the recognition of the rights granted by the Constitution as is the declaration of those rights themselves." ${ }^{344}$ If the states cannot offer such independence, the Federal courts must be prepared to carry the full responsibility of enforcement.

The empirical evidence that ballot accountability threatens judicial independence is admittedly slim. Although the average margin of victory in retention elections has steadily declined over the past two decades, ${ }^{345}$ thus

Arizona, California, Colorado, Florida, Illinois, Missouri, Nebraska, Oklahoma, South Dakota, and Wyoming. Montana and Utah provide for retention elections in the event that an incumbent has no opponent in a reelection bid. See infra Appendix B.

341. The range runs from every six years-in Arizona, Florida, Nebraska, and Oklahoma-to every 12 years in Missouri. See infra Appendix B.

342. See Colo. CoNsT. art. VI, § 25 . Nearly every substitutive plebiscite state which conducts retention elections provides for an initial ballot review within a very short time after the judge's appointment. With the time period in parentheses, these include Alaska ( 3 years), Arizona ( 2 years), California (next general election), Florida (1 year), Missouri (1 year), Nevada (3 years), Oklahoma (1 year), South Dakota ( 3 years) and Wyoming (1 year). See infra Appendix B.

343. See The Federalist No. 78, at 527 (A. Hamilton) (judicial independence needed to "guard the constitution and the rights of individuals from the effects of those ill humours which the arts of designing men, or the influence of particular conjunctures, sometimes disseminate among the people themselves"). Indeed, as Hamilton suggests, the need for judicial independence may be even greater where the constitutional invasions are "instigated by the major voice of the community." Id. at 528 .

344. Rehnquist, An Independent Judiciary: Bulwark of the Constitution, 9 N. ILL. U.L. REv. 1, 8 (1988).

345. See, e.g., Aspin \& Hall, Political Trust and Judicial Retention Elections, 9 LAw \& PoL'y 451, 461 (1987) [hereinafter Political Trust] (mean affirmative vote in retention elections for state trial courts was $85.7 \%$ in $1964,78.2 \%$ in 1972 , and $74.7 \%$ in 1980 ); Hall \& Aspin, What Tuenty Years of Judicial Retention Elections Have Told $U_{s}, 70$ Judicature 340, 344 (1987) [hereinafter Tuenty Years] (in 1964, 92.9\% of state trial court judges received affirmative votes of at least $80 \%$, in 1972 only $50 \%$, and by 1984 , only $26.4 \%$ ). A similar pattern can be observed among state appellate judges. In California, for example, the 21 Supreme Court justices who faced the electorate from 1942 
far relatively few incumbent appellate judges have actually been defeated. One recent article therefore scoffs at the "much-heralded and feared political accountability of the state bench," pointing out that only nine state court judges failed to win retention elections in 1985 and $1986 .^{346}$ Because voters in judicial elections are too ignorant and apathetic to punish judges for unpopular decisions, the article argues, judges have no reason to live in fear of electoral reprisal and will be unlikely to denigrate Federal constitutional rights to curry local favor. ${ }^{347}$

These conclusions paint with too broad a brush. The extent to which judicial elections impair judicial independence necessarily varies from issue to issue..$^{348}$ In no area would judges seem more at risk than when they overturn plebiscites. That voters are generally unaware and unmoved when legislative action is voided is not surprising. Judicial nullifications of ballot measures are different matters altogether. They tend to be highly visible decisions, which one recently deposed California justice has called "political hot potatoes." 348

Several studies have tentatively demonstrated that the likelihood of voting against judicial retention increases in direct proportion to a voter's level of knowledge. ${ }^{350}$ Most retention elections are issueless and colorless, and voters entering the voting booth do little besides registering their general confidence in the judicial system. As one study concludes, however, "the more the public knows about what the judges really do, the less inclined they are to support them." ${ }^{351}$ And-as three incumbent members of the California Supreme Court recently learned-nowhere are the voters likely to be more knowledgeable than on issues they have already been asked to pass upon.

It is admittedly simplistic to attribute the 1986 electoral defeat of Chief Justice Rose Bird and Associate Justices Joseph Grodin and Gruz Rey-

to 1962 received an average retention vote of $90 \%$. The fifteen who faced the voters from 1970 to 1982-not including Rose Bird who had peculiar problems at the polls-averaged an affirmative vote of $69 \%$. S'e Uelmen, Supreme Court Retention Elections in California, 28 SANTA Clara L. REv. 333,343 (1988).

346. Solimine \& Walker, State Court Protection of Federal Constitutional Rights, 12 Harv. J.L. \& Pub. Pol'y 127, $136 \&$ n.41 (1989). The authors are strangely untroubled by a trend in the other direction. In 1986, three California Supreme Court justices lost retention elections, three justices of the North Carolina Supreme Court lost partisan elections, and the Chief Justice of the Ohio Supreme Court was defeated in a non-partisan contest. See Uelmen, supra note 345, at 348; see also Hill, Taking Texas Judges Out of Politics: An Argument for Merit Election, 40 Baylor L. Rev. 339, 340 (1988) (describing trend toward electoral defeats of incumbent Texas judges).

347. Ser Solimine \& Walker, supra note 346, at 136; see also P. Dubois, From Ballot to BENCH 243-46 (1980) (describing generally low level of voter turnout and knowledge in judicial tections); Hall \& Aspin, Tuenty Years, supra note 345, at 340 (voters in retention election have little information on which to base their decisions).

348. See grnerally Neuborne, supra note 337, at 1128.

349. J. Grodin, supra note 12, at 105; see also Lowenstein, supra note 246, at 967-68 (decision on validity of initiative almost inevitably has high visibility).

350. See Aspin \& Hall, Political Trust, supra note 345, at 454 (citing several such studies).

351. Uelmen, supra note 345 , at 349. 
noso principally to voter dissatisfaction with their rulings on plebiscites. ${ }^{352}$ But it is equally erroneous to discount this factor. Bird and her colleagues were wounded deeply by their opinions undermining a death penalty initiative and-to a lesser extent-by a series of judicial blows administered to electoral control of legislative redistricting. The public perceived these actions as thwarting the will of the people, and the justices' opponents exploited this angle in their campaign literature. ${ }^{353}$

Nor were the 1986 elections the first in which California Supreme Court justices were called to account for their invalidation of plebiscitary action. In 1966, for example, those who voted in Reitman to strike down the initiative authorizing racial discrimination in the private housing market saw their margin of victory dramatically cut. ${ }^{354}$ In a 1982 preemptive attack, the justices up for reelection were the subject of a campaign designed to influence their votes on a pending challenge to a wide-ranging criminal justice initiative. ${ }^{365}$

The greater visibility of judicial decisions respecting plebiscites is not the only factor that renders such cases high risk for an elected judiciary. Plebiscites pass as a result of well-organized-and usually wellfinanced-organizations behind them. These groups are in place to mount anti-retention campaigns should the judiciary thwart their efforts. Monied special interests that have sunk considerable resources into the passage of a ballot measure may be willing to spend more to bump off the judges

352. See Thompson, supra note 189, at 2022-27, 2035-36 (attributing election results in part to Rose Bird's personality and to her perceived political agenda).

353. See id. at 2035 (barrage of public attacks from prosecutors and Governor led public to view court as thwarting public will on death penalty); see also id. at 2028-32 (deseribing court's handling of redistricting plebiscites). It may well be, however, that the death penalty is an issue of such high visibility that it mattered little that the Bird Court was dismantling an electoral command rather than a legislative one.

354. See id. at 2040 (justices who voted to declare housing initiative unconstitutional faced opposition like that seen in 1986 campaign). Chief Justice Roger Traynor's $65 \%$ retention vote represented a substantial drop from the $90 \%$ support he received just four years earlier. In 1962, only 360,000 Californians opposed retention. In 1966, principally as a result of this single decision invalidating a voter initiative, that figure rose to more than 1.7 million. Associate Justice Paul Peek, who was retained in 1964 with an $88 \%$ positive vote, saw his support dip to $62 \%$ just two years (and one initiative invalidation) later. See generally Uelmen, supra note 345 , at $341,343,345$. If one compares the negative votes cast against the justices who declared the housing initiative unconstitutional (averaging 1.76 million votes) with those cast against the one dissenter who appeared on that year's ballot (slightly less than 1 million votes) it appears that the judicial cost for thwarting the plebiscitary direction was a loss of approximately three-quarters of a million votes. See id. at 345 (Table II).

355. See Uelmen, Commentary: Are We Reprising a Finale or an Overture?, 61 S. CaL. L. Rev. 2069, 2071 (1988). Senatorial candidate Pete Wilson, for example, threatened personally to oppose any justice who voted against the initiative's validity. See Uelmen, supra note 345 , at 342 . Ultimately the initiative was upheld by a four to three decision issued eight weeks before Election Day. Three of the four justices up for reelection-including two of the court's most liberal members-voted with the majority. This prompted a significant number of suggestions-some rather harsh-of judicial cowardice. See Lowenstein, supra note 246 , at $937 \mathrm{nn} .12$ \& 13 . Subsequently Justice Otto Kaus candidly revealed uncertainty as to whether the campaign rhetoric affected his decision in the case. See Grodin, Judicial Elections: The California Experience, 70 JUDiCATURE 365, 368 (1987).

Similar threats of electoral reprisal were leveled at the California justices on the 1978 ballot as they prepared to hear a challenge to the constitutionality of Proposition 13, the property tax initiative. See L.A. Times, Aug. 12, 1978, at 1, col. 6 . 
who stand in the way of the measure's enforcement. Judges considering the constitutionality of voter efforts are not likely to be blind to the specter of an interest-group structure energized to carry out the same kind of voter campaign in displacing offending judges that was used in getting the plebiscite passed in the first place.

Enhanced judicial accountability for the invalidation of electoral legislation was not unintended by those who championed direct democracy. The reformers who sought greater electoral control over legislators foresaw the possibility of legislative bypasses being thwarted by an independent judiciary. ${ }^{356}$ It is not surprising, therefore, that the concept of retention elections was developed at the same time that states were embracing the initiative and the referendum. ${ }^{357}$ Reduction of judicial independence in the review of ballot measures was an integral part of the movement toward popular rule and away from filtered government.

It may well be impossible to establish empirically that the threat of electoral reprisal affects judicial behavior. ${ }^{358}$ We have little more to go on than occasional anecdote. For example, former California Supreme Court Justice Otto Kaus has confessed that his 1982 vote to uphold the constitutionality of a ballot initiative may have been induced-at a subconscious level-by the pendency of his retention election. ${ }^{358}$ Similar candor has been forthcoming from his former colleague, Joseph Grodin. Regarding whether his votes in a number of critical cases in 1986 were influenced by the upcoming election, Grodin's appraisal is a refreshingly honest "I just can't be sure." 380 A judge may hope that conscience will triumph over concern about retention, but as Otto Kaus put it, ignoring the political consequences of visible decisions is "like ignoring a crocodile in your bathtub." ${ }^{361}$ In spite of the obstacles to empirical validation, it hardly seems far-fetched that the most principled of jurists will hesitate-consciously or unconsciously - to void an electoral mandate in the face of a pending election. $^{362}$ Furthermore, even if we are to assume that some judges will be

356. Ste supra notes $183-87$ and accompanying text.

357. Sie S. Carbon \& L. Berkson, Judicial Retention Elections in the United States (1980).

358. See Thompson, supra note 189, at 2057 ("Given the confidential workings of courts, it is a formidable, if not impossible task to establish empirically the proposition that the prospect of a retention election influences the outcomes reached by appellate judges."). But see Solimine \& Walker, Constilutional Litigation in Federal and State Courts: An Empirical Analysis of Judicial Parity, 10 Hastings Const. L.Q. 213, 230-31 (1983) (suggesting that electoral accountability does not influence rulings of state court judges).

359. See Hager, Kaus Urges Reelection of Embattled Court Justices, L.A. Times, Sept. 28, 1986, at 3 , col. 5 .

360. See Grodin, Dezeloping a Consensus of Constraint: A Judge's Perspective on Judicial Retention Elections, 61 S. CAL. L. Rev. 1969, 1980 (1988).

361. See Reidinger, The Politics of Judging, 52 A.B.A. J., Apr. 1987, at 52, 58. The ability to ignore the crocodile doubtless depends on how long before you have to take a bath. When there is a substantial time gap between the rendering of a decision and the next election in which the judge must face the voters, he or she is likely to feel more independent.

362. It is no answer to say that judges who are unwilling to serve as crocodile food for the sake of 
able to ignore the prospect of voter reprisal and engage in serious "checking," the voters have the final word. Judges who fail to heed voter messages may soon find themselves replaced by those with better hearing.

Judicial review is most essential in the presence of unfiltered majoritarianism. Yet it is precisely the examination of voter action that puts elected judges at greatest risk. A judiciary that is directly accountable to the identical political forces which shaped the judgment under review may find it difficult to provide sustained enforcement of countermajoritarian constitutional norms. ${ }^{363}$ Direct democracy thus poses a peculiar threat to state judicial independence. Judicial filtering of plebiscitary action calls for nonaccountable judges. The Supreme Court ought to be sensitive to this special need when it decides which state court cases to review on certiorari and when it shapes the various federalism-inspired abstention doctrines.

While the Constitution's guarantee of a republican form of government does not demand that the states provide a structure with the panoply of Federal protections against factions, when the state departs from the vision reflected in each of the first three Articles-a bicameral legislative body, an executive with the power to veto, and an independent judiciary-the republican ideal is in danger of fading away. Here Federal court invocation of the Bill of Rights is more than a safety net-it may well be the only line of defense against majoritarian tyranny.

\section{Gonclusion: A Lingering DoubT}

I have not arrived at these conclusions easily. Limitations placed upon majoritarian preferences smack of paternalism and elitism. Of course, this difficulty recurs continually with our written Constitution and its judicial expositors. $^{364}$ But somehow its specter is more vivid when constitutional commands are invoked to negate popular preferences. Listen, for example, to Archibald Cox's response to Learned Hand's classic attack on judicial activism. "It would," decried Hand, "be most irksome to be ruled by a bevy of Platonic Guardians." ${ }^{365}$ How, asked Cox, could one feel that way about the Supreme Court's invalidation of a statute passed by the Massachusetts legislature? Modern government is "too remote and too few issues are fought out in elections, for a citizen to feel much more sense of

\footnotetext{
principle should not be judges in the first place. See Thompson, supra note 189, at 2062 (outcomes reached by judges with characteristics justifying their appointment are not likely to be influenced by prospect of retention elections). It is precisely the principled judges-like Kaus and Grodin-whose candor and integrity will compel them to question their own fortitude in the face of the crocodile. The unprincipled ones will simply step out of the tub without telling us about it.

363. See Neuborne, supra note 337, at 1127.

364. See Schauer, supra note 250 , at $787-88$ (suggesting that it may be time to face up to paternalism of Constitution).

365. If Platonic Guardians were in charge, Hand went on to say, "I should miss the stimulus of living in a society where I have, at least theoretically, some part in the direction of public affairs." $L$. Hand, The Bill. of Rights 73-74 (1958).
} 
participation in the legislative process than the judicial." But, conceded Cox, "I should be no less irked than Judge Hand if the Supreme Court were to void an ordinance adopted in the open Town Meeting in the New England town in which I live." 368

Now plebiscites-especially statewide ones-are not quite the same as the New England town meeting, but citizens are likely to feel substantially more connected and personally involved with them than with the remote action of their elected representatives. It is one thing for a court to undertake the task of protecting the people from their government and quite another to protect the people from themselves. True, the people of a state are very different from "the People" of the United States, but that is a cute academic argument, and I am not sure how it would play in Peoria.

Precisely because judicial actions regarding ballot measures are highly visible, there is a substantial danger that these decisions will engender popular cynicism to a degree not ordinarily found when courts toil unseen in the legislative vineyards. ${ }^{367}$ By appearing to remove popular majorities from meaningful input into the making of public policy, we run the risk that these majorities will cease to see these issues as something they ought to care about. ${ }^{368}$

Plebiscites serve as an escape valve for the frustrations of day-to-day encounters with faceless, unresponsive, and oppressive bureaucracies. If courts afford this spleen-venting little deference, and we block judicial accountability by placing the dirty task of checking in the Federal court, will something have to give? Could it take the form of diminished respect for and obedience to the courts, resentment toward Washington by an increasingly alienated populace, or apathetic retreats from civic responsibility? Our level of electoral participation is already the lowest among any Western nation. There is a real danger that the few citizens who still vote will cease to do so as they perceive that small power elites make all basic decisions, that elections change little or nothing, and that government does not really care what the "little person" thinks. ${ }^{369}$

But courts can minimize the impact of invalidating voter legislation. Judges should steer clear of reviewing ballot measures before enactment. ${ }^{370}$ It is no doubt likely that visibility will be greater after a measure

366. A. Cox, The Role of the Supreme Court in American Government 116 (1976).

367. See P. McGuigan, supra note 15, at 141 ("As the courts move increasingly to thwart popular decision making, it is difficult to see how popular cynicism and discontent can be contained.").

368. Cf. Schauer, supra note 250 , at 783 (by removing majorities from meaningful input into free speech issues, we risk those majorities' ceasing to see free speech as something they ought to care about).

369. See W. Burnham, supra note 41, at 153; see also C. Pateman, supra note 19, at 104 (discussing correlation between apathy and low feelings of political efficacy); Frug, supra note 19, at 1070 (power and participation are inextricably linked; sense of powerlessness tends to produce apathy).

370. Ser J. Grodin, supra note 12, at 106 (outlining advantages of post-election review over pre- 
has been passed, but the possibility that the measure may not pass is significant. Voters occasionally demonstrate surprising sensitivity to the rights of minorities. Witness the 1978 defeat of a California ballot initiative designed to restrict the rights of homosexual public school teachers, and the 1986 defeat of Lyndon LaRouche's attempt to empower California health authorities to quarantine AIDS victims. ${ }^{371}$ There is no need for courts to step in on behalf of minorities unless it is clear that there is no other way to protect their interests. The judiciary's ability to command popular acceptance is a limited resource and should not be squandered on hypothetical transgressions. ${ }^{372}$

There is no denying that protecting republicanism is a high-stakes proposition. The very volatility of transient passions both warrants stricter review of direct democracy and renders execution of this task by the Federal judiciary a treacherous venture. People care deeply about many of these plebiscitary issues. Unless, however, we are willing to abandon our commitment to the principles upon which our government is founded, we must be willing to confront the danger to minority rights and individual liberty posed by a device that aggregates without filtering.

election review of ballot measures); Gordon \& Magleby, Pre-Election Judicial Renieu' of Initiativess and Referendums, 64 NOTRE DAME L. REv. 298 (1989) (arguing impropriety of pre-election adjudication of challenges to measures' substantive validity); see also Legislature v. Deukmejian, $34 \mathrm{Cal} .3 \mathrm{~d}$ 658, 669 P.2d 17, 194 Cal. Rptr. 781 (1983) (constitutional challenges to substance of ballot measures are usually more appropriately reviewed after election).

371. Sep T. Cronin, supra note 16, at 96.

372. The route to Federal court may in any event be foreclosed for pre-election challenges because of justiciability or abstention problems. See generally Gordon \& Magleby, supra note 370, at 304-11 (discussing advisory opinion and ripeness bars to pre-election substantive review). 


\section{APPENDIX A: THE PREVALENCE OF DIRECT DEMOCRACY}

$\begin{array}{ll}\text { STATE } & \begin{array}{c}\text { SUBSTITUTIVE } \\ \text { PLEBISCITES }\end{array} \\ \end{array}$

legislative constitutional mandatory voluntary popular constitutional initiative initiative referendum referendum referendum referendum

Ala.

Alaska

$\begin{array}{ll}\mathrm{X} & \\ \mathrm{X} & \mathrm{X} \\ \mathrm{X} & \mathrm{X} \\ \mathrm{X} & \mathrm{X} \\ \mathrm{X} & \mathrm{X}\end{array}$

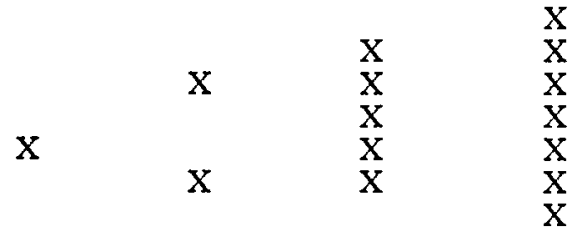

Ariz.

Ark.

Cal.

Colo.

Conn.

Del.

Fla.

Ga.

Haw.

Idaho $\mathrm{X}$

Ill.

Ind,

Iowa

Kan.

Ky. b

La.

Me.

Md.

Mass.

Mich.

Minn.

$\mathrm{X}$

$\underset{X}{X}$

$\mathrm{X}$

$\underset{\mathrm{X}}{\mathrm{X}}$

Miss.

Mo.

Mont.

Neb.

Nev.

N.H.

N.J.

N.M.

N.Y.

N.C.

N.D.

Ohio

Okla.

Or.

$\mathrm{Pa}$.

R.I.

S.C.

S.D.

$\mathrm{b}$
$\mathrm{X}$
$\mathrm{b}$
$\mathrm{X}$
$\mathrm{X}$
$\mathrm{c}$
$\mathrm{X}$
$\mathrm{X}$
$\mathrm{X}$
$\mathrm{X}$
$\mathrm{X}$

$\mathrm{Xa}$

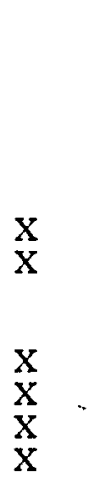

$X$
$X$
$X d$

X

$\underset{\mathrm{X}}{\mathrm{X}}$

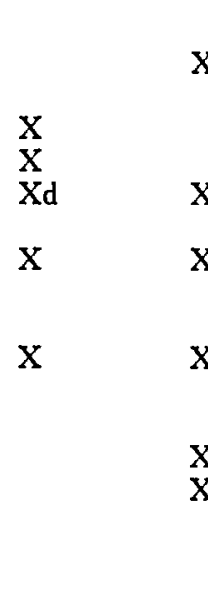

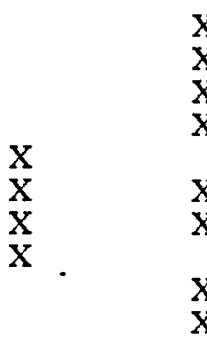

$\mathrm{X}$

$\mathrm{X}$

$\mathrm{X}$

$\mathrm{Xd} \quad \mathrm{Xd} \quad \mathrm{X} d$

$\mathrm{X}$

$\mathrm{X}$

$\mathrm{X}$
$\mathrm{X}$
$\mathrm{X}$
$\mathrm{X}$

$\mathrm{X}$

$\mathrm{X} \quad \mathrm{X}$

$\mathrm{X}$

$\mathrm{X}$

$\mathrm{X}$

$\mathrm{x}$

$\mathrm{X}$

$\mathrm{X}$

$\mathrm{X}$

$\begin{array}{ccc} & & \mathrm{X} \\ & \mathrm{X} & \mathrm{X} \\ \mathrm{X} & \mathrm{X} \\ \mathrm{X} & \mathrm{X} & \mathrm{X} \\ & \mathrm{X} & \mathrm{X} \\ & & \mathrm{X} \\ & & \mathrm{X} \\ & & \mathrm{X}\end{array}$

$\mathrm{X}$
$\mathrm{X}$
$\mathrm{X}$
$\mathrm{X}$
$\mathrm{X}$
$\mathrm{X}$

a - pertains to the legislative article of constitution only.

b - although these states permit voters to initiate referenda on legislative enactments, these so-called popular referenda are better characterized as complementary plebiscites.

c - recent efforts to provide for substantive plebiscites narrowly defeated by the voters.

d - applies only to legislation classifying property and to property taxes. 


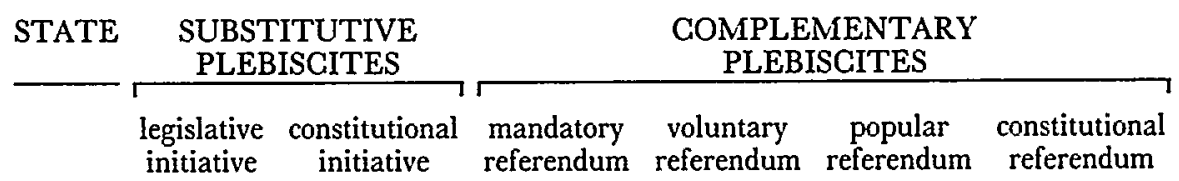

Tenn.

Tex.

Utah X

Vt.

Va.

Wash. $\mathrm{X}$

W. Va.

Wis.

Wyo.

$\begin{array}{cccc} & & \mathrm{X} \\ & & \mathrm{X} & \mathrm{X} \\ \mathrm{X} & \mathrm{X} & \mathrm{X} \\ \mathrm{x} & \mathrm{X} & \mathrm{X} & \mathrm{X} \\ & \mathrm{X} & & \mathrm{X} \\ & & \mathrm{X} & \mathrm{X}\end{array}$

a - pertains to the legislative article of constitution only.

b - although these states permit voters to initiate referenda on legislative enactments, these so-called popular referenda are better characterized as complementary plebiscites.

c - recent efforts to provide for substantive plebiscites narrowly defeated by the voters.

$\mathrm{d}-$ applies only to legislation classifying property and to property taxes.

Sources: Council of State Governments, The Book of the States, 1988-89, at 18, 217-19; Referendums: A CoMparative Study of Practice and Theory 71-72 (D. Butler \& A. Ranney eds. 1978); Voter Initiative Constitutional Amendment, 1977: Hearings on S.J. Res. 67 Eefore the Subcomm. on the Const. of the Senate Comm. on the Judiciary, 95th Cong., 1st Sess. (1977). 
APPENDIX B: ELECTORAL ACCOUNTABILITY OF STATE JUDGES

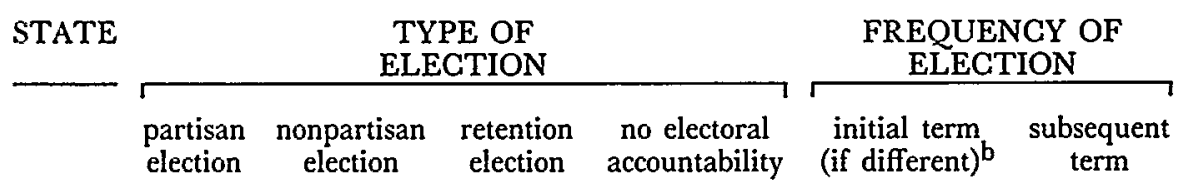

\begin{tabular}{|c|c|c|c|c|c|c|}
\hline Ala. & $\mathrm{X}$ & & & & & 6 \\
\hline Alaska & & & $X$ & & 3 & 10 \\
\hline Ariz. & & & $\mathrm{X}$ & & 2 & 6 \\
\hline Ark. & $x$ & & & & & 8 \\
\hline Cal. & & & $\mathrm{X}$ & & c & $12 d$ \\
\hline Colo. & & & $\mathrm{X}$ & & 2 & 10 \\
\hline Conn. & & & & $\underset{\mathrm{X}}{\mathrm{X}}$ & & \\
\hline $\begin{array}{l}\text { Del. } \\
\text { Fla. }\end{array}$ & & & $\mathrm{X}$ & & c & 6 \\
\hline $\mathrm{Ga}$. & $\mathrm{X}$ & & 22 & & 6 & \\
\hline $\begin{array}{l}\text { Haw. } \\
\text { Idaho }\end{array}$ & & $x$ & & $X$ & & 6 \\
\hline Ill. & & & $X$ & & & 10 \\
\hline Ind. & & & $X$ & & 2 & 10 \\
\hline lowa & & & $\mathrm{X}$ & & 1 & 8 \\
\hline Kan. & & & $\mathrm{X}$ & & 1 & 6 \\
\hline Ky. & & $\mathrm{X}$ & & & & 8 \\
\hline La. & & $\mathrm{x}$ & & & & 10 \\
\hline Me. & & & & $\mathrm{X}$ & & \\
\hline Md. & & & $\mathrm{X}$ & & 1 & 10 \\
\hline Mass. & & & & $\mathrm{X}$ & & \\
\hline Mich. & & $\mathrm{X}$ & & & & 8 \\
\hline Minn. & & $x$ & & & & 6 \\
\hline Miss. & $\mathrm{x}$ & & & & & 8 \\
\hline Mo. & & & $\mathrm{X}$ & & 1 & 12 \\
\hline Mant. & & $\mathrm{Xa}$ & & & & 8 \\
\hline $\begin{array}{l}\text { Neb. } \\
\text { Nev. }\end{array}$ & & $\mathrm{X}$ & $\mathrm{x}$ & & 3 & 6 \\
\hline $\begin{array}{l}\text { Nev. } \\
\text { N.H. }\end{array}$ & & $\Lambda$ & & $\mathrm{X}$ & & \\
\hline N.J. & & & & $X$ & & \\
\hline N.M. & $\mathrm{X}$ & & & & & 8 \\
\hline N.Y. & & & & $\mathrm{X}$ & & \\
\hline N.C. & $\mathrm{X}$ & & & & & 8 \\
\hline N.D. & & $X$ & & & & 10 \\
\hline Ohio & & $\mathrm{X}$ & & & & 6 \\
\hline Okla. & & & $\mathrm{X}$ & & 1 & 6 \\
\hline Or. & & $\mathrm{X}$ & & & & 6 \\
\hline $\mathrm{Pa}$. & & & $\mathrm{X}$ & & & 10 \\
\hline R.I. & & & & $\mathrm{X}$ & & \\
\hline S.C. & & & & $\mathrm{X}$ & & \\
\hline S.D. & & & $\mathrm{X}$ & & & 8 \\
\hline
\end{tabular}

a - retention election held if judge is unopposed.

b - states which have shorter initial terms subject judges to retention vote at the next general election but establish a minimum number of years within which the judges need not come before the voters. The numbers provided denote that minimum.

$c$ - initial retention election held at first general election subsequent to appointment.

d - California Supreme Court justices may be subject to a second election in less than the 12 year period if they have filled an unexpired term of a prior justice. 


$\begin{array}{lccccc}\begin{array}{l}\text { partisan } \\ \text { election }\end{array} & \begin{array}{c}\text { nonpartisan } \\ \text { election }\end{array} & \begin{array}{c}\text { retention } \\ \text { election }\end{array} & \begin{array}{c}\text { no electoral } \\ \text { accountability }\end{array} & \begin{array}{c}\text { initial term } \\ \text { (if different) }\end{array} & \begin{array}{c}\text { subsequent } \\ \text { term }\end{array}\end{array}$

Tenn.
Tex.

$\mathrm{X}$

election accountability

term

$\mathrm{X}$

8

Utah

$\mathrm{Xa}$

10

$\mathrm{Vt}$.

Va.

Wash.

W. Va. $\mathrm{X}$

$\mathrm{Xa}$

$\mathrm{X}$

$\mathrm{X}$

Wis.

Wyo.

$\mathrm{X}$

$\mathrm{X}$

12

10

1

8

a - retention election held if judge is unopposed.

b - states which have shorter initial terms subject judges to retention vote at the next general election but establish a minimum number of years within which the judges need not come before the voters. The numbers provided denote that minimum.

c - initial retention election held at first general election subsequent to appointment.

d - California Supreme Court justices, may be subject to a second election in less than the 12 year period if they have filled an unexpired term of a prior justice.

Sources: L. Berkson, S. Beller \& M. Grimaldi, Judicial Selection in the United States: A Compendium of Provisions 18-21 (1980); S. Cafibon \& L. Berkson, Judicial Retention Elections in the United States 70-78 (1980); Council of State Governments, The Book OF THE STATES, 1988-89, at 157-58, 163-65. 